O norden

\title{
Virksomheders indsats for udsatte unge (Företags insatser för utsatta unga)
}

De gode eksempler i Norden (goda nordiska exempel) 

2 norden 



\section{Virksomheders indsats for udsatte unge \\ (Företags insatser för utsatta unga)}

De gode eksempler i Norden

(goda nordiska exempel)

DAMVAD og Kontigo

TemaNord 2013:586 
Virksomheders indsats for udsatte unge(Företags insatser för utsatta unga)

De gode eksempler i Norden(goda nordiska exempel)

DAMVAD og Kontigo

ISBN 978-92-893-2663-6

http://dx.doi.org/10.6027/TN2013-586

TemaNord 2013:586

(C) Nordisk Ministerråd 2013

Layout: Hanne Lebech

Omslagsfoto: ImageSelect

Denne rapport er udgivet med finansiel støtte fra Nordisk Ministerråd. Indholdet i rapporten afspejler dog ikke nødvendigvis Nordisk Ministerråds synspunkter, meninger, holdninger eller anbefalinger.

www.norden.org/da/publikationer

\section{Det nordiske samarbejde}

Det nordiske samarbejde er en af verdens mest omfattende regionale samarbejdsformer. Samarbejdet omfatter Danmark, Finland, Island, Norge og Sverige samt Færøerne, Grønland og Åland.

Det nordiske samarbejde er både politisk, økonomisk og kulturelt forankret, og er en vigtig medspiller i det europæiske og internationale samarbejde. Det nordiske fællesskab arbejder for et stærkt Norden i et stærkt Europa.

Det nordiske samarbejde ønsker at styrke nordiske og regionale interesser og værdier i en global omverden. Fælles værdier landene imellem er med til at styrke Nordens position som en af verdens mest innovative og konkurrencedygtige regioner.

Nordisk Ministerråd

Ved Stranden 18

1061 København $\mathrm{K}$

Telefon (+45) 33960200

www.norden.org 


\section{Indholdsfortegnelse}

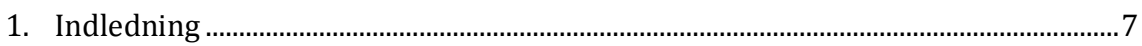

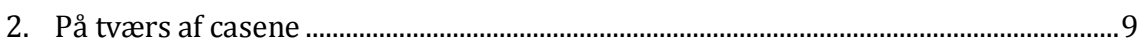

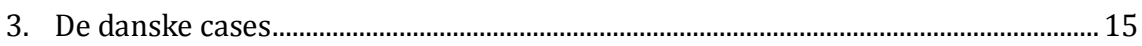

3.1 Øens Murerfirma................................................................................................ 15

3.2 Falck Danmarks Uddannelsesforløb............................................................... 20

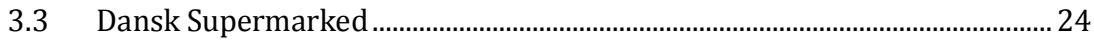

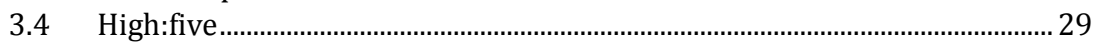

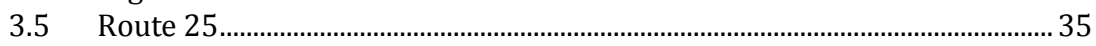

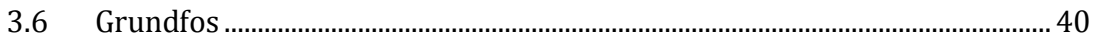

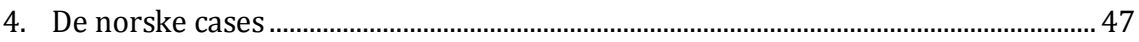

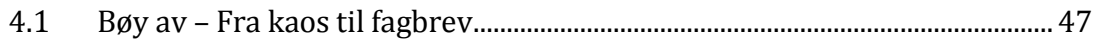

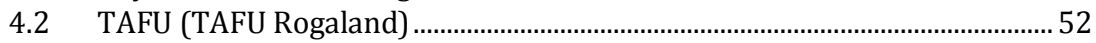

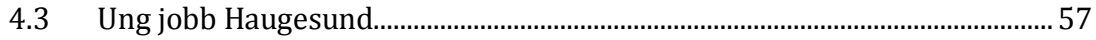

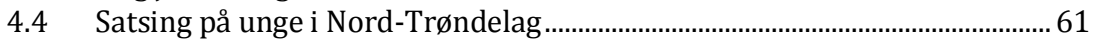

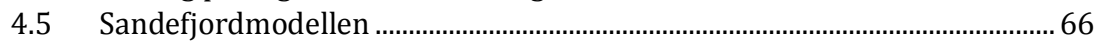

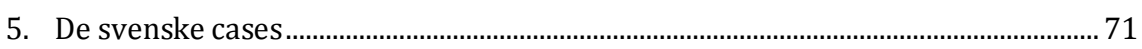

5.1 ABB ungdomssatsningar/IF Metalls Yrkesintroduktionsår.......................... 71

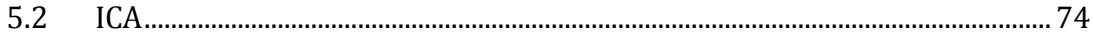

5.3 Telge Tillväxt......................................................................................................... 78

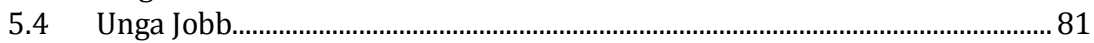

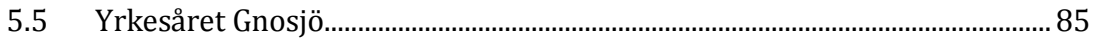

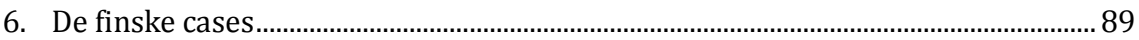

6.1 Läroavtalskampanjen "nappaa nuori töihin" (Plocka in ungdomen

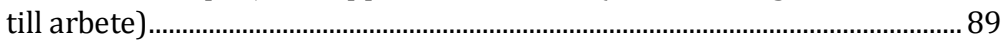

6.2 "Uusien mahdollisuuksien tori" (Nya möjligheternas torg, UMT) i

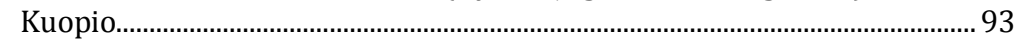

6.3 Vastuullinen Kesäduuni (Ansvarsfullt sommarjobb, VKD) ......................... 96

6.4 Duunita Mut! (Ge mig ett jobb!) ................................................................... 101

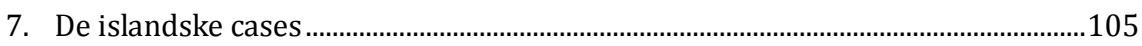

7.1 Job Forum Reykjavík (Atvinnutorg í Reykjavík) ..........................................105

7.2 Opportunity - Young People to Action (Ungt fólk til athafna

(Skagastaðir)) ………………….......................................................................108

7.3 Icelandair Technical Services..................................................................111

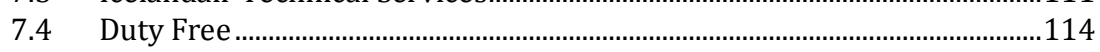





\section{Indledning}

Høj arbejdsløshed blandt unge i Norden

Arbejdsløsheden blandt unge er betydelig større end den generelle arbejdsløshed i de nordiske lande. En voksende gruppe af unge i Norden har risiko for ikke at komme ind på arbejdsmarkedet - ikke blot som ung, men også i deres voksne liv (Norden, 2012). ${ }^{1}$ Ungdomsarbejdsløshed er en af de store problemstillinger på arbejdsmarkedet ikke kun i Norden, men i hele Europa. I EU's medlemsstater var over 23 \% af de unge under 25 år uden arbejde ved udgangen af 2012 (Eurostat). ${ }^{2}$ I Sverige er ungdomsarbejdsløsheden lige over gennemsnittet i EU, mens den i Finland er lige under. Situationen er en del bedre i Danmark, Island og især i Norge. Men selv i disse tre lande er omkring 8-15\% af de unge under 25 år uden arbejde. Især Danmark har haft en stor stigning i ungdomsarbejdsløsheden siden finanskrisens komme i 2008-2009. I Norge skal tallene ses i lyset af en meget lav samlet arbejdsløshed i 2012 nemlig 3,2 \%.

\begin{tabular}{lcccc}
\hline & \multicolumn{2}{c}{ Ungdomsarbejdsløshed i pct. } & \multicolumn{2}{c}{ Arbejdsløsheden i pct. } \\
& $\mathbf{2 0 0 8}$ & $\mathbf{2 0 1 2}$ & $\mathbf{2 0 0 8}$ & $\mathbf{2 0 1 2}$ \\
\hline Danmark & 8,0 & 14,1 & 3,4 & 7,5 \\
Norge & 7,3 & 8,6 & 2,5 & 3,2 \\
Sverige & 20,2 & 23,7 & 6,2 & 8,0 \\
Finland & 16,5 & 19,0 & 6,4 & 7,7 \\
Island & 8,2 & 13,6 & 3,0 & 6,0 \\
\hline
\end{tabular}

Kilde: Eurostat.

\section{Virksomheder er centrale aktører i bekæmpelsen af ungdomsarbejdsløsheden}

Virksomheder og arbejdsgivere har altid været involveret i spørgsmål om kompetenceforsyning både lokalt og nationalt, men har nu i stigende grad fået opmærksomhed på ungdomsarbejdsløsheden i samfundet generelt. Flere og flere virksomheder tager et ansvar i forhold til at hjælpe de unge nærmere en plads på arbejdsmarkedet. Ligesom virksomheder-

\footnotetext{
${ }^{1}$ Nord 2012:005, Unge på Kanten - Om inkludering af utsatte ungdommer.

${ }^{2}$ http://epp.eurostat.ec.europa.eu/statistics_explained/index.php/Youth_unemployment
} 
nes øgede deltagelse i andre sociale spørgsmål såsom menneskerettigheder eller klima og miljø, oplever flere og flere virksomheder, at de har et ansvar når det kommer til at give unge en mulighed for at komme ind på arbejdsmarkedet. Virksomhederne engagerer sig i sociale indsatser, ikke blot ud fra perspektivet om at sikre levering af arbejdskraft til egen virksomhed eller industri, men også med baggrund i et mere langsigtet samfundsøkonomisk perspektiv.

Ofte kan virksomheden være vejen til at komme videre i uddannelse eller få læreplads for en ung arbejdsløs. Aktivering i virksomheder ses af flere som en af de mest effektive måder til at få svage grupper af ledige i arbejde. Virksomhederne kan tilbyde de udsatte unge noget andet end fx en sagsbehandler eller et skoleophold kan. De unge får bl.a. mulighed for at prøve sig selv af i forbindelse med forskellige arbejdsopgaver og brancher, og de lærer noget om ansvar, samarbejde og arbejdsmarkedskultur.

\section{Undersøgelsens fokus - best practice}

Denne undersøgelse kortlægger eksempler på best practice for virksomheders indsatser for at sikre, at udsatte unge med svag forankring på arbejdsmarkedet kommer i beskæftigelse eller uddannelse. Kortlægningen ser på praksis i de fem nordiske lande: Danmark, Norge, Sverige, Finland og Island. De udvalgte cases har alle til formål at sikre udsatte unges integration på arbejdsmarkedet. Casene omfatter både:

- Selvstændige virksomhedstiltag, som har forøget tilknytningen til arbejdsmarkedet og øget ansættelsesmulighederne for unge, der hidtil har haft en svag forankring på arbejdsmarkedet.

- Samarbejdstiltag med andre aktører, som har medført, at virksomheder har ansat unge med svag forankring på arbejdsmarkedet, eller hvor samarbejdet har bidraget til en vellykket overgang mellem uddannelse og arbejdsmarkedet og har formået at fastholde unge på arbejdsmarkedet.

Mens de enkelte landes cases beskrives i kapitel 3-8, kigger næste kapitel på tværs af de enkelte cases og opsummerer de centrale forudsætninger for succesfuld integration af de udsatte unge på arbejdsmarkedet. 


\section{På tværs af casene}

\section{Målgruppen er udsatte unge med svage forudsætninger for uddannelse}

Målgruppen i de fleste cases er unge ledige i alderen 16-25 år, nogle op til 30 år. Langt størstedelen er unge mænd, som oftest har en svagere tilknytning til arbejdsmarkedet. Andre kendetegn for de unge, som indgår i flere cases, er følgende:

- Svag social baggrund og svag familiemæssig opbakning, $\mathrm{fx}$ omsorgssvigt i barndommen, misbrug i familien mv.

- Opvokset i socialt belastede områder.

- Kriminelle eller på kant med loven.

- Lavt uddannede eller uden uddannelse - heraf en stor del, som ikke har færdiggjort grundskolen.

- Mangel på sociale kompetencer fx erfaring med, hvordan man agerer på en arbejdsplads og i sociale sammenhænge generelt og udfordringer med at håndtere praktiske forhold i hverdagen.

- Misbrugsproblemer af forskellig slags.

- Psykiske eller fysiske lidelser - fx ADHD.

- Indlæringsvanskeligheder og dårlige læse-, skrive og regnekundskaber.

- Anden etnisk baggrund og heraf følgende sprogvanskeligheder.

- Manglende viden om deres vej til og muligheder for uddannelse og job.

Flere cases viser, at de unge, som indsatserne fungerer godt for, er unge med en vis motivation for forandring i deres liv og unge, som ønsker at udnytte denne chance for forandring. Ligeledes vurderes indsatserne særligt at fungere godt for de unge, som oplever en positiv effekt af anerkendelse, ros og inklusion i et fællesskab, da det er forhold som kan flytte motivationen og tilliden til arbejde.

De unge som indsatserne har svært ved at opnå succes med er unge, der ikke har motivation for en forandring i deres liv. De er ikke motiverede og villige til at indgå i en virksomhed på de præmisser der følger med. Nogle cases viser dog, at indsatserne også har opnået succes med unge uden umiddelbar motivation for forandring i livet. Det handler om at arbejde længe og dybt nok med den unge, så der skabes den nødven- 
dige motivation, tillid og tro på, at en forandring er mulig. Dette kræver tid og ressourcer - og ikke mindst vilje fra såvel virksomheden som de samarbejdende aktører.

\section{Mange aktører deltager $\mathrm{i}$ arbejdet med udsatte unge}

Flere af de gode eksempler er kendetegnet ved, at der er mange aktører involveret i indsatserne, som hjælper de unge tættere på arbejdsmarkedet. Fælles for aktørerne i de gode cases er, at de koordinerer deres indsats, samarbejder på tværs af fagligheder og arbejder struktureret og engageret med de udsatte unge.

Nedenfor præsenteres de væsentligste faktorer på tværs af casene for myndighedsaktørers succesfulde rolle i indsatserne, derefter de væsentligste faktorer i virksomhedernes rolle og til sidst de væsentligste faktorer i samspillet mellem myndighedsaktørerne og virksomhederne. Disse faktorer er alle opmærksomhedspunkter, som man kan lære af på tværs af de nordiske lande såvel som inden for de enkelte lande.

\section{Myndighedsaktører som prioriterer ungdomsarbejdsløsheden}

I langt de fleste cases spiller offentlige myndigheder en essentiel rolle. Ofte er det arbejdsformidlingen, som er den centrale myndighedsaktør, men også misbrugsvejledningen, ungdomsuddannelsesvejledningen samt forskellige dele af den kommunale forvaltning er centrale myndighedsakt $\varnothing$ rer. Flere af casene indebærer, at der oprettes specifikke myndighedsinstitutioner, som har ansvaret for kontakten med den unge.

På tværs af de mange cases fremstår følgende forhold som særligt centrale i myndighedsindsatsen for, at det bidrager til en succesfuld indsats for de udsatte unge:

- Politisk og ledelsesmæssig prioritering. Indsatsen for udsatte unge skal have politisk og ledelsesmæssig opmærksomhed - og skal prioriteres. Dette sikrer de nødvendige ressourcer, bevågenhed og opbakning til en indsats for udsatte unge.

- En resultatorienteret tilgang med overskuelige og opnåelige delmål for den unge og systematisk opfølgning herpå. Der skal konstant være fokus på at skabe resultater for de udsatte unge og på at følge op ved hjælp af en handleplan, som anvendes aktivt og løbende.

- Visitationen af de udsatte unge skal foregå hurtigt og kvalificeret og ud fra en erkendelse af, at det kræver ressourcer at afdække udsatte borgeres potentialer og barrierer.

- Individuelt, tilrettelagt indsats ud fra den unges kompetencer, ressourcer og behov. Dette kræver tilstrækkelig kendskab til den unge, dennes udfordringer, potentialer og ønsker. 
- Udnytte den unges motivation. Det er afgørende at handle når den unges motivation er til stede. Hvis en indsats skal være succesfuld, skal den unge kunne se meningen med den og have mod på den.

- Helhedsorienteret, borgerfokuseret indsats. Den unge skal ikke selv koordinere, sikre helhed og sammenhæng - det skal de professionelle. Den unge skal være i centrum for opgaven - ikke systemet.

- Tværfagligt samarbejde mellem forskellige faggrupper. Tilstedeværelse af relevante og forskellige kompetencer er vigtigt, og kompetenceudvikling kan være nødvendig.

- Fælles forståelse blandt myndighedspersonerne. Der skal skabes en fælles forståelse af borgerens udviklingsmål og udarbejdes en fælles plan for, hvordan borgeren når målet - ellers kan indsatserne risikere at spænde ben for hinanden.

\section{Virksomheder som ønsker at tage et socialt ansvar - får loyale medarbejdere til gengæld}

Ud over myndighedspersonerne spiller virksomhederne selvsagt en helt særlig rolle i de beskrevne cases.

Flere af casene viser, at virksomhederne internt forbereder sig på at integrere de udsatte unge. Flere virksomheder peger her på følgende forhold som vigtige for at integrationen af den udsatte unge bliver succefuld:

- Tilbyde et fleksibel og individuelt tilpasset forløb - fx med fleksible arbejdstider til den unge, eller opgaver som er tilpasset til den unges ressourcer.

- Skab et tillidsbaseret og konsekvent forhold til kontaktperson. Den person, som den unge er i kontakt med, skal have den rette balance af fast og blød hånd - en hånd som både kan håndtere en del af de problemstillinger som kan opstår for målgruppen samt udvise forståelse og empati for den unge.

- En forholdsvis struktureret og bevidst plan for den unges opstart som sikrer, at den unge tages imod med åbenhed og venlighed, men også med krav og forventninger. Indsatsen bør tilrettelægges ud fra den unges kompetencer, ressourcer og behov og der kan med fordel arbejdes med at sætte overskuelige og opnåelige delmål for den unge.

- Vis den unge konsekvens, respekt og værdsættelse. Respektér den unge og sæt rammer og klare grænser. Men samtidigt er det vigtigt at værdsætte, hvad den unge gør og signalere denne værdsættelse til den unge.

- Giv ansvar og stil krav. Stil krav og stol på medarbejderen fra et meget tidligt tidspunkt i forløbet, så snart den unge er klar til det. Jo før en ung udsat bliver behandlet som den resterende medarbejderstab, des 
før oplever den unge at være en del af virksomheden. Samtidig er det vigtigt langsomt at øge det ansvar og de krav, der stilles til den unge.

- Opbakning fra topledelsen til at integrere udsatte unge i virksomheden. Det er vigtigt at der prioriteres de nødvendige ressourcer til opgaven fra ledelsens side.

- Opbakning fra eksisterende medarbejdere. De eksisterende medarbejdere skal gerne have en positiv indstilling og respektere den unge for den person vedkommende er, mere end for vedkommendes baggrund. I den forbindelse er det vigtigt, at man i virksomheden snakker åbent med eksisterende medarbejdere om integrationen af de udsatte unge.

\section{Det gode samarbejde mellem virksomheden og myndighederne}

Det er helt centralt, at der er et godt samarbejde mellem virksomhederne og myndighederne, fx jobcenteret eller arbejdsformidlingen. Centrale faktorer, som i flere cases fremgår som essentielle for det succesfulde samarbejde, er bl.a.:

- Faste samarbejdsaftaler mellem arbejdsformidlingen og virksomhederne. Flere virksomheder har faste samarbejdssamtaler med arbejdsformidlingen, hvilket de oplever som meget positivt og vigtigt for at påtage sig ansvaret for at inkludere den unge.

- Klar forventningsafstemning om den unges opgaver og kompetencer. I den forbindelse er det vigtigt, at jobkonsulenten er ærlig over for virksomheden om alle forhold omkring den unge, således at virksomheden er forberedt bedst muligt.

- Matchning. Virksomhederne skal - når det er muligt - tilbydes unge, som kan anvendes til de funktioner, som der særligt er brug for i virksomheden. Derved sikres størst "win-win" oplevelse for virksomheden og den unge, idet virksomheden får løftet nogle opgaver og den unge oplever at kunne bidrage til virksomheden.

- Faste kontaktpersoner på begge sider, så der kun er én indgang. Faren er særligt, at hvis der er for mange kontaktpersoner og derved indgange, bliver samarbejdet for tungt for virksomheden, og denne springer fra.

- God og rummelig mentor. En mentor er en voksen der støtter og hjælper den unge med at navigere i forhold til støtteordninger, arbejdspladskultur og -opgaver mv., og som den unge kan få et tillidsfuldt og fortroligt forhold til. Dette kan både være en mentor på virksomheden (virksomhedsmentor) eller en ekstern fx fra jobcenteret (socialmentor).

- Jævnlig opfølgning på virksomheden af myndighedspersonen. Den fysiske tilstedeværelse af en myndighedsperson på virksomheden er 
vigtigt. Den medvirker til at sikre det gode kendskab til virksomheden, og hvad de unge foretager sig.

- Fastholdelse og opfølgning ved overgange. Det er særligt vigtigt at den unges støttes i overgange - $\mathrm{fx}$ fra virksomhedspraktik til uddannelse, eller fra indsats til rigtig arbejde, så den unge ikke springer fra hvis den unge møder udfordringer i overgangen.

- Minimere omkostninger for virksomhederne. Virksomhederne skal i forvejen ligge ressourcer i oplæring mv., hvorfor det er vigtigt, at minimere ekstra tid og ressourcer for dem. Dette indebærer bl.a. at minimere virksomhedens administrationsomkostninger på etableringen af virksomhedspraktikken. 



\section{De danske cases}

\section{1 Øens Murerfirma}

\subsubsection{Kort om initiativet}

Øens Murerfirma er et murer- og entreprenørfirma med lige knap 200 ansatte, der hovedsagligt beskæftiger sig med renoveringsopgaver inden for murer-, beton- og kloakarbejde. Øens Murerfirma har en lang historie for at tage et samfundsmæssigt ansvar, særligt overfor udsatte unge. Virksomhedsejerne har fra starten haft den indstilling; banker nogen på døren, så hjælper de dem. Den sociale ansvarlighed som virksomheden påtager sig, opleves som ikke alene foreneligt med at drive virksomhed, men også udbytterigt for begge parter. Deres mål er, foruden at afklare de unge om deres kompetencer, at sikre de unge ordinær beskæftigelse enten hos dem selv eller hos deres samarbejdspartnere. Firmaets personalepolitik lægger på flere måder vægt på inklusion af alle. Konkret udmønter det sig i vide muligheder for individuelt tilpassede arbejdstider, så den enkelte kan bevare tilknytningen, ligesom den enkelte kan omplaceres, flyttes til andre arbejdsfunktioner eller blive ansat på fleks- eller seniorvilkår.

\subsubsection{Resultater}

Øens Murerfirma har i årevis haft deres sociale indsats som en integreret del af deres virksomhedsdrift. Deres ambition er at øge succesraten, dvs. andelen af unge som får beskæftigelse hos dem selv eller i deres netværk, da det både gavner de unge og virksomheden selv. De oplever selv, at deres indsats giver pote, når de kan være med til at give disse unge nogle oplevelser og give dem lyst til at beskæftige sig med noget. De modtager op til 18 praktikanter i kvartalet fra jobcentrene og modtager dermed ca. 50 praktikanter på årsbasis. Omkring $20 \%$ af de unge får beskæftigelse hos dem, dvs. enten på en byggeplads, på deres ejendomskontorer eller hos deres samarbejdspartnere/underleverandører. 


\subsubsection{Målgruppen}

Målgruppen er primært ledige unge i alderen 18-25 år. Det er næsten uden undtagelse unge mænd, der som oftest ingen tilknytning har til arbejdsmarkedet. De er typisk opvokset i socialt belastede områder, lavt uddannede eller ufaglærte og en stor del af dem har ikke færdiggjort grundskolen. En væsentlig barriere for målgruppen er mangel på sociale kompetencer, $\mathrm{fx}$ erfaring med at hvordan man agerer på en arbejdsplads. Samtidig har mange af dem misbrugsproblemer. I den senere tid er jobcentrene begyndt at brede målgruppen lidt ud til også at omfatte personer med psykiske lidelser, som Øens Murerfirma ligeledes prøver at indsluse.

Både virksomhedskonsulenterne fra jobcentrene og Øens Murerfirma peger på, at de unge, der klarer sig bedst, er dem, som vælger at udnytte deres chance. Indsatsen virker således bedst for de unge, der er motiverede og som oplever en positiv effekt af anerkendelse, ros og inklusion i fællesskabet. Dette kan både omfatte unge, som har evnerne, men som har sociale problemer med i bagagen, og unge, som har været langvarigt uden for arbejdsmarkedet.

\subsubsection{Virksomhedens rolle og gevinst}

De unge starter i en indledende praktikperiode på fire uger, hvor de får en introduktion til arbejdspladsen og afstemmer forventninger. Praktikken handler om at give de unge en indføring i, hvordan man opfører sig på en arbejdsplads. Gradvist krydres det med forskellige arbejdsopgaver og de begynder også at holde morgenmøder, hvilket munder ud i gradvist flere krav til de unge i det omfang de er klar til det. I denne indledende fase lægges der meget vægt på at de unge skal blive en del af fællesskabet og at de skal have ros og succesoplevelser som fortjent, da det motiverer de unge, der oftest ikke tidligere har fået megen ros og anerkendelse.

Efter de fire uger kommer de unge, der har udvist tilstrækkelig vilje og (faglig) interesse, ud på en byggeplads i 13 uger, som er den egentlige praktikperiode, hvor de bliver en del af et sjak. Hvis de klarer det godt kan det resultere i et jobtilbud eller en lærlingeplads som murerarbejdsmand eller inden for et andet specialiseret område.

Øens Murerfirma har dedikeret en person, som er koordinator for de øvrige fem mentoruddannede murerformænd, til at stå for al kontakten med de unge. Det er således ham, der har den faste kontakt og dialog med såvel de unge og virksomhedskonsulenterne på jobcentrene, og han bistår dem også i overgangen fra den indledende periode til byggepladsen. Den faste kontaktperson kender virksomhedskonsulenterne i jobcentrene, så hvis han oplever problemer med nogle af de unge, så ringer 
han til virksomhedskonsulenterne, som kender de pågældende unge. Virksomhedskonsulenterne ringer også lejlighedsvist for at følge op, og besøger virksomheden en gang hver anden uge med henblik på at følge op på hvordan det går.

Øens Murerfirma oplever, at det giver dem en goodwill og et godt omdømme i branchen, hvilket er blevet et af deres kendemærker i deres virksomhedsprofil, samtidig med at den sociale ansvarlighed er en rekrutteringskanal, der også giver dem gode og loyale ambassadører for virksomheden. Endvidere fremhæver virksomhedskonsulenterne, at Øens Murefirma via praktikordningerne får noget dynamik ind i virksomheden, hvilket giver nogle andre vinkler på det daglige arbejde, ligesom de medgiver, at det er en potentielt god rekrutteringsmodel.

\subsubsection{Samarbejde med andre aktører}

Øens Murerfirma har faste samarbejdsaftaler med fire kommunale jobcentre; Brøndby, Greve, Herlev og København. Her har de bl.a. brochurer liggende, som kan bevidstgøre de unge om muligheden for at komme i praktik hos dem.

Der er faste kontaktpersoner i jobcentrenes virksomhedsteams såvel som hos Øens Murerfirma. Alle parter lægger vægt på, at et godt og engageret samarbejde, som de ser som uvurderligt for at skabe en god social indsats. Tillid, god kommunikation, forventningsafstemning, opfølgning og fysisk tilstedeværelse nævnes som centrale faktorer for det succesfulde samarbejde. Det tætte samarbejde mellem Øens Murefirma og jobcentrene betyder, at de forskellige kontaktpersoner kender hinanden godt. Det gør det eksempelvis nemt for jobcenteret at matche unge med virksomheden, og gør at jobcentrene i visse tilfælde kan sende en bredere målgruppe af unge til virksomheden - unge som andre virksomheder har svært ved at integrere og håndtere. Ligeledes kan Øens Murerfirma ubesværet kontakte virksomhedskonsulenterne, hvis der skal drøftes noget om de unge, hvilket har vist sig at være særligt væsentligt flere gange. Eksempelvis hvis de skifter fra kursus til at skulle arbejde på byggepladsen er det vigtigt at kommunikationen omkring de fysiske skift er god, så det sikres at den unge ikke falder fra. Virksomhedskonsulenternes engagement i forbindelse med deres besøg på virksomheden hver anden uge er også med til at konsolidere det gode samarbejde, så de unge oplever en nærværende indsats, der holder hånden under dem.

Alle parter nævner også, at det tager tid hvis man vil have det gode match til at lykkes og afliver i et vist omfang myten om det perfekte match. Der er bedre matches end andre, men med det rigtige samarbejde 
og en god indsats kan man få det til at lykkes. Det er væsentligt at virksomhedskonsulenterne afsætter tilstrækkeligt med tid til såvel fysiske besøg, opfølgningssamtaler og assistance i forbindelse med den nødvendige administration. Især administrationen nævner Øens Murerfirma som et forhold, hvor de har behov for jobcenterets hjælp til at tage det ud af hænderne på dem, så de ikke spilder tiden på det.

\subsubsection{Finansiering}

Øens Murerfirma har, som andre danske virksomheder, ikke lønomkostninger til de unge under praktikforløbene, idet de modtager kontanthjælp under hele praktikperioden. Det resterende finansierer Øren Murerfirma som udgangspunkt selv, men søger jobcenteret om refusion i særlige tilfælde. Eksempelvis har de haft en ung, der led af posttraumatisk stresssyndrom, hvor de fik refusion for denne. Jobcentrene yder dog lejlighedsvist økonomisk støtte til fx arbejdstøj til de unge, eller mentorbistand til den faste kontaktperson for nogle af de timer, som han bruger på at indsluse de unge. Dog vurderer virksomhedskonsulenterne, at kontaktpersonen bruger flere timer end han får refusion for.

\subsubsection{Forudsætninger for succes}

De centrale forudsætninger for succes er særligt de faktorer, som beskrives i forbindelse med det gode samarbejde mellem jobcentrene og virksomheden, idet Øens Murerfirmas indsats afhænger fuldkommen af samarbejdets karakter. Virksomheden selv og virksomhedskonsulenterne peger på, at såfremt der ikke er god kommunikation, tillid, engagement og der ikke bliver holdt hvad der bliver lovet, så er der en risiko for at ansvaret glider væk. Øens Murerfirma har også oplevet at måtte opgive samarbejdet med nogle jobcentre, fordi der ikke var nok tillid og stor nok villighed til at dedikere den fornødne tid til samarbejdet. Det er helt afgørende at der er faste kontaktpersoner på begge sider og at der er en klar forventningsafstemning såfremt mønstret i disse kontaktpersoner ændrer sig.

Det er også det faste samarbejde der muliggør, at man kan komme helt i dybden med problemstillingerne og udvikle nye metodikker i indsatsen. Den fysiske tilstedeværelse, som er med til at sikre det gode kendskab til virksomheden og hvad de unge foretager sig, er også meget vigtig. Samtidig er det meget væsentligt for Øens Murerfirmas succes med den sociale ansvarlighed, at de bruger så mange ressourcer på det, fordi alle i virksomheden er afklaret om, hvad det indebærer at yde en social indsats. 


\subsubsection{Udbredelse af indsatsen}

Særligt for Øens Murerfirma er, at de har mentoruddannede murerformænd og en mentorkoordinator. Disse er alle meget rummelige mennesker og ældre mænd, der med deres livserfaring kan fungere i en faderrolle for de unge. Det er af stor betydning. Herudover kan mentorerne hjælpe de unge rent fagligt. På den måde har virksomheden formentligt nogle lidt specielle kulturelle og arbejdsmæssige betingelser, som det er værd at være opmærksom, men som ikke nødvendigvis i sig selv betyder, at andre virksomheder ikke kan tage ved lære af deres indsats.

Også faste kontaktpersoner er centralt for den succesfulde indsats i Øens Murerfirma. Hvis et jobcenter gerne vil samarbejde kræver det, at man prioriterer at være ude ved virksomheden og tage opfølgningen alvorligt gennem faste aftaler.

Øens Murerfirmas eksempel viser, at de udsatte unge også kan være et aktiv for virksomheden, ligesom det giver noget for dem på et personligt plan at beskæftige sig med socialt ansvar.

Øens Murerfirmas sociale ansvarlighed drevet af et stærkt engagement og virksomheden er gennemsyret af en stærk vilje til at få det til at lykkes. Dette er vigtigt, at en virksomhed gør sig ansvaret klart, hvis de vælger at engagere sig. Det trækker nogle ressourcer i form af tid, mentorordninger. Endvidere er det vigtigt, at medarbejdere er indstillet på, hvordan de skal forholde sig til de unge, hvis man vil tage et socialt ansvar. Samlet vurderes der ikke, at være noget så særegent omkring Øens Murerfirmas indsats, at andre virksomheder ikke skulle kunne iværksætte lignende tiltag, men det kræver at virksomhederne er indstillet på det.

\subsubsection{Kilder}

Interview med Anja Keyser, virksomhedskonsulent i København Jobcenter. Interview med Rene Colding, administrerende direktør, Øens Murerfirma. Interview med Casper Hansen, virksomhedskonsulent, Herlev Jobcenter. Interview med Vagn Fjeldsted, virksomhedskonsulent, Københavns jobcenter. http://vfsa.dk/people+prize/tidligere+vindere/csr+people+prize+2012/vindere+2 012/dommerbegrundelse+\%C3\%B8ens+murerfirma http://www.oensmurer.dk/

Casen er bl.a. anbefalet af: Beskæftigelses- og Integrationscentret, Jobcenter Københavns Kommune, Vinder af CSR People Prize 2012. 


\subsection{Falck Danmarks Uddannelsesforløb}

\subsubsection{Kort om initiativet}

Falck Danmark er en redningsvirksomhed med ca. 9.000 ansatte, som varetager alt fra ambulancekørsel og autoredning til brandslukning og sygetransport. Falck udfører en hel del CSR-relateret arbejde rundt om på forskellige stationer i landet, herunder samarbejde med lokale jobcentre om forskellige indsatser for både utilpassede og ikkeutilpassede unge. Indsatserne omfatter bl.a. virksomhedspraktikker, brandslukningskurser, mentorordninger mv.

I maj 2011 påbegyndte Falck et projekt, der forløb frem til april 2013. I samarbejde med en erhvervsskole tilrettelagde virksomheden en erhvervsuddannelse med speciale i auto. Halvdelen af 24 elevpladser på den nye autoredderuddannelse blev øremærket til udsatte unge, for at give dem en chance for at finde fodfæste på arbejdsmarkedet. Målet var, at de unge skulle gennemføre uddannelsen og herigennem opbygge faglige såvel som sociale kompetencer, der kunne kvalificere til ansættelse enten hos Falck eller på det øvrige arbejdsmarked. For Falck var dette en stor og vigtig aktivitet at lykkes med. Det ligger dybt i virksomheden qua deres arbejdsopgaver at hjælpe andre mennesker. Casebeskrivelsen fokuserer på dette projekt.

\subsubsection{Resultater}

Det er med projektet lykkedes at inkludere langt de fleste af de udsatte unge til uddannelse og ansættelse gennem virksomhedspraktik med mentorstøtte. Mere end halvdelen af de unge er i dag fastansat hos Falck, andre er ansat som timelønnede indtil der bliver faste stillinger og èn blev via Falck ansat hos en af Falcks underleverandører. Med disse positive resultater og et meget begrænset frafald undervejs - kun en enkelt, der ikke gennemførte til slut - betegnes forløbet af Falck som værende særdeles succesfuldt. Hvad angik eksamensresultaterne lå holdets gennemsnit markant over skolens tidligere hold, og flere af de unge scorede topkarakterer på det, der var deres første succes med gennemførelse af et uddannelsesforløb.

\subsubsection{Målgruppen}

Målgruppen i projektet er socialt udsatte unge, der af forskellige årsager har dårlig eller ingen tilknytning til arbejdsmarkedet. De unge har af forskellige årsager ikke kunne finde fodfæste på arbejdsmarkedet. Årsa- 
gerne er alt fra omsorgssvigt i barndommen, stofmisbruger, forældre med misbrug, kriminalitet og dertilhørende pletter på straffeattesten, indlæringsvanskeligheder til at have sproglige barrierer grundet anden etnisk baggrund. De unges barrierer i forhold til at komme på arbejdsmarkedet varierer derfor betydeligt og for nogle er flere af førnævnte forhold gældende.

\subsubsection{Virksomhedens rolle og gevinst}

Inden de unge starter i uddannelsesforløbet, indledes deres forløb med en virksomhedspraktik på 4-8 uger. Hensigten er at afklare, om den unge har lyst til at komme under uddannelse i Falck og en gensidig forventningsafstemning. De 4-8 ugers praktik alene er ikke tilstrækkelige til at få den unge på ret kurs, men det sikrer en vigtigt afklaring af, om uddannelsesforløbet er noget for den unge. Praktikperioden er således vigtig for varig succesfuld fastholdelse af den unge på arbejdsmarkedet.

Efter praktikforløbet indledes et år og ni måneders uddannelsesforløb, hvor de udsatte unge sammen med andre unge uddannes som autoredder. De udsatte unge får hver tilknyttet en mentor, som de kan vende forskellige problemstillinger med. Mentoren er en vigtig del af forløbet, da opbygning af tillid mellem den udsatte unge og mentoren er vigtigt for den unges muligheder for succesfuld gennemførsel af uddannelsesforløbet. Falck-mentorernes tilgang til de unge er en kombination af kærlig og fast hånd. Den kærlige hånd bruges, da mange af de unge er omsorgssvigtede og derfor kun sjældent har oplevet at andre bekymrer sig om dem. Den faste hånd sætter faste rammer, som den unge heller ikke har været vant til. Den faste hånd kommer bl.a. til udtryk, hvis de unge udebliver uden forklaring. Dette accepteres ikke, og hvis det sker, bliver de unge hentet hjemme hos dem selv. Balancen mellem den faste og kærlige hånd er helt essentiel for uddannelsesforløbets succes.

Inden de unge påbegynder deres virksomhedspraktik klæder Falck de udvalgte mentorer og ledere på til at håndtere de unge, således at de bedst muligt kan tackle potentielle problemer, som kan opstå. Desuden bliver de resterende medarbejdere orienteret om de unges start på virksomheden, og hvilke hensyn der skal tages, således der ikke kommer snak i krogene på arbejdspladsen.

Projektet med at tage udsatte unge ind på elevpladser, har givet Falck flere gevinster som virksomhed. Projektet har bidraget til at udbrede kendskabet til Falck som en socialt ansvarlig arbejdsplads med medarbejdere med "hjertet på rette sted". Desuden er der er brug for de unge især når arbejdsmarkedet ændrer sig - hvor det kan være svært at finde 
kvalificeret arbejdskraft. De unge, der går succesfuldt igennem uddannelsesforløb, er karakteriseret ved at være utroligt loyale medarbejdere og ambassadører for Falck. Endvidere bliver Falck, ifølge dem selv, en klogere virksomhed, da de får nye perspektiver og viden, som bliver en integreret del af virksomheden. En viden som også gør dem klogere på kundernes behov. Endelig bidrager det til at skabe sammenhold og stolthed på nye måder i organisationen.

\subsubsection{Samarbejde med andre aktører}

I forbindelse med projektet samarbejdede Falck med virksomhedsnetværket VINSA, nu VirksomhedsnetværkCabi. VINSA hjalp Falck med at finde nogle unge, der kunne komme i virksomhedspraktik og herefter uddannelse. Desuden mødte en medarbejder fra VINSA op sammen med den unge ved praktikstart, for at hjælpe til med at afklare, hvorvidt der var grundlag for et videre uddannelsesforløb. Denne mulighed eksisterer ikke længere på samme måde, hvorfor selve identifikationen og afklaringen af mulige kandidater må håndteres af Falck selv i samarbejde med eksempelvis jobcentre og andre aktører. Afklaringen af den unge er helt central for unges mulighed for succes med uddannelsesforløbet.

Kontakten til det offentlige, er meget vigtigt. Falcks erfaringer er i den forbindelse, at det er fordelagtigt at have en ekstern person knyttet som er bindeled til det offentlige. Dette minimerer faren for, at virksomheden oplever kontakten med et jobcenter som for bøvlet og derfor dropper samarbejdet. En god og simpel model for samarbejdet med det offentlige er derfor vigtigt, for en succesfuld integration af udsatte unge på arbejdsmarkedet.

\subsubsection{Finansiering}

Finansieringen af uddannelsesforløbet for de udsatte unge følger samme model som for andre unge. Under den praktikperiode som de udsatte unge havde inden start på uddannelsesforløbet, er de samme regler gældende som for andre ledige der kommer i praktik. Men de ressourcer som Falck desuden bruger på at lave uddannelsesforløbet er egne udgifter. Finansieringen er selvfølgelig også et aspekt, der overvejes hos Falck. For Falck er det en balancegang mellem at være en privat virksomhed, som skal begå sig et konkurrencemiljø og samtidig have hjertet med sig. Da initiativet blev sat i gang, var der fra politisk side sikret et mere gunstigt grundlag for den økonomiske del af projektet. Et grundlag som ikke længere eksisterer i samme grad. I fremtiden ønsker Falck 
fortsat at have en tilgang, hvor der lægges vægt på CSR-perspektivet, men det skal stadig balancere i forhold til de forretningsmæssige mål.

\subsubsection{Forudsætninger for succes}

Kombinationen af et praktikforløb, som fungerer afklarende og et uddannelsesforløb, som uddanner og opkvalificerer den unge, har i dette projekt haft positive resultater. Virksomhedspraktikken hjælper til at afklare de unge i forhold til faget og gav de unge socialt sammenhold på arbejdspladsen, der gav dem mod og tro på at fortsætte. Men praktikforløbet alene sikrer ikke, at den unge fastholdelse på arbejdsmarkedet. Det er det lange seje træk med at uddanne de unge, som sikrer de unge bliver forankret på arbejdsmarkedet. Ofte er det individuelle faktorer, som afgør den enkelte unges succes, men en række faktorer som virksomheden og det offentlige kan påvirke er ligeledes vigtige forudsætninger for succes:

- Opbakning fra topledelsen til at integrere udsatte unge i virksomheden. Et projekt som Falcks kræver ressourcer, hvorfor det er vigtigt at der prioriteres de nødvendige ressourcer til opgaven fra ledelsens side. Dette omfatter også tid og ressourcer til adfærdsregulering, håndtering af udeblivelser, uforudsete problemer mv. Endvidere er det centralt for de eksisterende medarbejdere at vide, at ledelsen bakker op om projektet.

- En ekstern kontaktperson, som fungerer som forbindelsesled til det offentlige system, gør samarbejdet med forskellige offentlige myndigheder meget nemmere, og risikoen for at tabe de unge i overgange mv. minimeres.

- En god og rummelig mentor som den unge kan få et tillidsfuldt og fortroligt forhold til. Det er her vigtigt, at mentoren fungerer som mentor i hele perioden, også uden for arbejdstid.

- Den daglige leder skal have den rette balance af fast hånd og blød hånd. Vedkommende skal kunne håndtere en del af de problemstillinger som kan opstå for målgruppen, samt kunne håndtere de skuffelser der kan være i forhold til den enkelte unge.

- Det er vigtigt at man i virksomheden snakker åbent med eksisterende medarbejdere om integrationen af de udsatte unge. Herunder hvor medarbejdernes grænser går og hvordan eventuelle problemer skal håndteres, fx hvem griber ind og hvem informeres mv. Det er ligeledes vigtigt at de eksisterende medarbejdere har en positiv indstilling og respekterer den unge for den person vedkommende er mere end for vedkommendes baggrund. Åben snak gør medarbejderne i stand til at 
håndtere mulige udfordringer, men også at den unge kan føle sig velkommen.

- En mere eller mindre struktureret plan for den unges opstart, som sikrer at den unge tages imod med åbenhed og venlighed, men også med krav og forventninger. Det vigtigt at den unge ikke bliver "nurset" igennem det hele forløbet - jo før man begynder at behandle de unge som helt almindelig medarbejdere jo bedre. En tydeliggjort holdning til hvor meget man vil håndholde og hvor længe er derfor central.

\subsubsection{Udbredelse af indsatsen}

Falcks projekt er startet i samarbejde med VINSA, men på Falcks eget initiativ. Hvis virksomheder har viljen til det, vurderes projekter som disse godt at kunne udbredes. Det centrale for en succesfuld udbredelse er overensstemmelsen med virksomhedens værdisæt - forankret på alle virksomhedens niveauer. Eksisterende medarbejders vilje til at deltage i et sådan projekt er ligeledes essentielt for projektets succes. Almindelige menneskelige egenskaber som viljen og evnen til at bruge tid på dialog, på at lytte, udvise tolerance, hjertelighed og empati er "alt" hvad der skal til for skabe grobund for at skabe tillidsfulde relationer mellem medarbejderne, lederen, mentoren og den nye unge kollega.

\subsubsection{Kilder}

Interview med Lise Pagh, HR Chef, Falck Danmarks.

Interview med Leif Christiansen, Stationsleder assistance, Falck Toftlund.

http://www.falck.dk/SiteCollectionDocuments/Om\%20Falck/Hjaelp/HJÆLP\%20se ptember\%202011.pdf

http://vinsa.dk/projekter/ungeprojektet/film+om+falckprojekt

Casen er bl.a. anbefalet af Virksomhedsforum for Socialt Ansvar (VFSA).

\subsection{Dansk Supermarked}

\subsubsection{Kort om initiativet}

Dansk Supermarked er en detailhandelsvirksomhed med flere supermarkedskæder, der i alt beskæftiger 35.000 medarbejdere. Siden 1990'erne har virksomheden arbejdet målrettet med at tilbyde udsatte unge en chance for at komme ind på arbejdsmarkedet. Virksomheden 
laver individuelt tilpasset praktikforløb, der struktureres efter praktikantens kompetencer og udfordringer.

Det centrale for Dansk Supermarked er en tro på potentialet i det enkelte menneske og et ønske om at afspejle mangfoldigheden i samfundet, så virksomhedens kunder møder samme bredde i butikkerne, som ude i samfundet. Dette fokus udgør det sociale ansvar som Dansk Supermarked ønsker at påtage sig.

\subsubsection{Resultater}

Dansk Supermarkeds sociale engagement resultater i, at der i samarbejde med 60 af landets kommuner årligt tilbydes ca. 1.200-1.500 praktikforløb, hvor den enkelte bliver afprøvet i et tilpasset forløb, i forhold til de begrænsninger og kompetencer vedkommende måtte have.

En del af praktikforløbene i Dansk Supermarked er arbejdsprøvninger, dvs. de har til formål at afklare, hvor meget den enkelte kan arbejde og har dermed ikke job som mål. Men en del af praktikforløbene har også til formål at skabe en jobåbning enten i virksomheden eller andre steder. Når dette er tilfældet, bliver personen efterfølgende ansat, så vidt det kan lade sig gøre, enten ordinære vilkår eller med brug af støtteordninger. Ca. en tredjedel af de 1.200-1.500 praktikforløb ender i ansættelse.

Et resultat af Dansk Supermarkeds sociale engagement ses også på antallet af medarbejdere med anden etnisk baggrund end dansk, som udgør ca. $15 \%$ af alle ansatte i Dansk Supermarked. Dette målrettede arbejde med integration og mangfoldighed resulterede i 2012 i tildelingen af Integrationsprisen for årets arbejdsplads. Desuden blev Dansk Supermarked i samme år nomineret til CSR People Prize i kategorien for større virksomheder for deres professionelle arbejde med indslusning og herunder specielt arbejdsprøvning og praktikforløb for udsatte unge.

\subsubsection{Målgruppe}

Målgruppen for Dansk Supermarkeds indsats overfor udsatte unge spænder bredt. Det omfatter både unge, som har været på kant med loven, nydanskere der har sproglige udfordringer eller unge med psykiske eller fysiske begrænsninger, fx udviklingshæmmede eller ADHD.

Udfordringen for udviklingshæmmede i varetagelsen af et job kan bestå, i at personen har vanskeligheder med sprog, motorik og med kontakten til andre mennesker. Ligeledes kan psykiske lidelser også spille ind. Nogle unge med ADHD har ekstra udfordringer på et job, da de kan have sværere end andre ved at holde opmærksomhed på opgaver, høre 
efter eller følge instruktioner, organisere, håndtere skift fra en opgave til en anden, fornemme tid og har muligvis til tider et stort temperament eller svingende humør. Når målgruppen er unge på kant med loven, er det særligt vigtigt, at de unge meget hurtigt i forløbet oplever, at der bliver stillet krav og givet ansvar, således at de hurtigst muligt kan føle sig som en del af virksomheden. Målgruppens udfordringer er således forskellig, hvilke gør det særlig centralt med individuelt tilpasset praktikforløb for de unge.

\subsubsection{Virksomhedens rolle og gevinst}

De tilpassede praktikforløb som etableres for den enkelte praktikant, struktureres individuelt afhængig af praktikantens kompetencer. Så hvis den unge med svag tilknytning til arbejdsmarkedet har ADHD, fokuseres der fx særligt på struktur i arbejdet og eller fleksible arbejdstider. Er den udsatte evnesvag, kan det være at fokus lægges på at vedkommende kun skal løse én opgave, fx at presse pap. Er der tale om en utilpasset ung, fokuseres der på, at der meget tidligt i praktikforløbet udvises respekt og tillid til den unge og samtidig gives ansvar.

I forbindelse med ADHD har Dansk Supermarked haft et ønske om en større indsigt i sygdommen, for at tilegne sig større viden omkring sygdommen og hvilke konsekvenser den medfører i det daglige arbejde. Med denne viden er virksomheden blevet i stand til at strukturere arbejdsgangene på en måde således at det passer virksomheden og den udsatte rigtig godt. Virksomheden har således selv engageret sig i at få den nødvendige viden som gør det nemmere at integrere udsatte unge i Dansk Supermarkeds butikker.

De unge bliver desuden tildelt en mentor, som sikrer at den unge har en fast person at rådføre sig hos. Denne funktion er vigtig, da de unge ofte ingen idé har om hvilke uskrevne regler og normer, som eksisterer på en arbejdsplads. Mentoren medvirker derfor til at den unge bedst muligt bliver en integreret del af arbejdspladsen. Efterfølgende er nogle af de unge, som har været igennem et praktikforløb, selv blevet mentorer, hvilket har vist sig at give stor succes for både virksomheden og de unge. Disse udvikler sig til loyale medarbejdere, som bliver i virksomheden, hvilket betyder mindre udskiftning i medarbejderstaben og færre ressourcer brugt på ansættelsesprocesser. Dette har været en yderligere gevinst for virksomheden.

I etableringen af praktikforløbene lægges der vægt på, at der fra starten af et praktikforløb snakkes åbent omkring det, såvel med de eksisterende medarbejdere, som med praktikanterne. Det sikrer, at der ikke 
"snakkes i krogene" i den enkelte afdeling hvilket sikrer en hurtig accept fra medarbejderstaben. De sociale relationer omkring praktikforløbene udvikler sig til at medarbejderne omkring de unge får et forhold til dem, hvorfor der drages omsorg for dem. Det sikrer, at der skabes et nyt fællesskab omkring den unge, - et fællesskab som giver de udsatte unge rollemodeller, og som er med til at øge chancen for efterfølgende fastholdelse på arbejdsmarkedet.

De mange praktikforløb har også betydet kompetenceudvikling af de eksisterende medarbejdere, da arbejdet med udsatte unge kan kræve et anderledes og større fokus end i arbejdet med andre medarbejdere. Derfor har Dansk Supermarked etableret et grundkursus i anerkendende ledelse, samt frivillige kurser i mangfoldighedsledelse for deres ledere og chefer. Dette sikrer, at ledere og chefer er klædt tilstrækkeligt på, til at imødegå opgaven med de udsatte unge, uanset deres baggrund.

Der er flere gevinster for Dansk Supermarked. For det første er der et rekrutteringsperspektiv. Dansk Supermarked har kontakt til størstedelen af landets kommuner, hvilket kan bruges i rekrutteringsøjemed. Samarbejdet går flere år tilbage, specielt før 2007, hvor det var vanskeligere at skaffe kvalificeret arbejdskraft. For det andet så er det en gevinst $i$ et det CSR-perspektiv. De pågældende Føtex- og Bilka-varehuse er store virksomheder i de lokalområder de er placeret $\mathrm{i}$, og agerer dermed som socialt ansvarlige i deres lokal område ved at integrere udsatte unge i deres lokale virksomheder.

\subsubsection{Samarbejde med andre aktører}

Dansk Supermarked samarbejder med over 60 af landets 98 kommuner. Samarbejdet er enormt vigtigt for virksomheden og foregår i forbindelse med alle typer af udsatte som Dansk Supermarked søger at få i beskæftigelse.

For Dansk Supermarked er et succesfuldt samarbejde med jobcentrene karakteriseret ved en lokalforankring, hvor der er én indgang begge steder. Dette forstået således at der ude i den enkelte supermarked er en fast kontaktperson i det lokale jobcenter, så der ikke skal bruges unødig tid fra både virksomheden og det offentliges side på at søge rundt efter den i forhold til problemstillingen rette person. Afhængig af problemstillingen får Dansk Supermarked fat i en jobkonsulent i jobcenteret, som kan vejlede dem $\mathrm{fx}$ om mulighederne for at lave en fastholdelsesordning for en medarbejder der ellers skulle have været afskediget.

Desuden samarbejder Dansk Supermarkeds HR-afdeling med forskellige organisationer, bl.a. med LEV, som er en landsdækkende forening 
for udviklingshæmmede mennesker og ADHD-foreningen. Dette gøres for at få en bedre forståelse for unge med fx ADHD og for at kunne skabe de bedst mulige rammer på arbejdspladsen for dem. Endvidere har Dansk Supermarked samarbejdet med High:Five og i den forbindelse taget unge ind, som har en plettet straffeattest.

\subsubsection{Finansiering}

De ressourcer som Dansk Supermarked har valgt at bruge på kontaktpersoner, uddannelse af ledere og medarbejdere og vidensopbygning omkring fx ADHD finansierer Dansk Supermarked selv. Dog modtager Dansk Supermarked mentorstøtte til nogle af de udsatte borgere. Dvs. at en virksomhedsmentor (person i Dansk Supermarked) bliver frikøbt 2-5 timer om ugen af kommunen til at støtte op om den udsatte unge. Desuden betaler Dansk Supermarked, som andre danske virksomheder, ikke løn under praktikopholdet til de ledige, da den ledige får en ydelse fra a-kassen eller kommunen. Ydelsen svarer til de dagpenge, som et ledigt medlem af en akasse ellers ville være berettiget til, eller den kontanthjælp, som ledige kontanthjælpsmodtagere ellers ville modtage.

\subsubsection{Forudsætninger for succes}

Centrale forudsætninger for at opnå succesfulde praktikforløb i Dansk Supermarked er, at uanset hvilken årsag der ligger til grund for unge den svage forankring på arbejdsmarkedet, så er det vigtigt at:

- Respektér, stil krav og stol på medarbejderen fra et meget tidligt tidspunkt i forløbet. Jo før en ung udsat bliver behandlet som den resterende medarbejderstab, des før fungerer integrationen med arbejdsmarkedet bedre.

- Opbakning fra medarbejderne. Værdien af at medarbejderne bakker op skal ikke underkendes. Ledelsen skal selvfølgelig bakke op om initiativet, men værdierne og ønsket om at fastholde unge med svagforankring på arbejdsmarkedet skal skabes fra bunden.

- Værdsættelse og signalering heraf. Den enkelte skal føle sig værdsat og det skal signaleres, at opgaven som den unge løser er vigtig.

- Individuelt tilpassede forløb. Enhver som starter i praktik- og mentorforløb får et tilpasset forløb, således at der tages hensyn til den enkeltes evner og kompetencer. Kompetenceafstemning er helt essentielt. 
- En indgang begge steder. Det lokale jobcenter skal nemt kunne komme i kontakt med den lokale forretning, og omvendt skal virksomheden nemt og hurtigt kunne komme i kontakt med joncenteret. Sker dette ikke bliver samarbejdet for tungt og virksomheden springer fra.

\subsubsection{Udbredelse af indsatsen}

Dansk Supermarked er i sit arbejde med udsatte unge hjulpet af, at der er mange unge mennesker i detailhandlen. Dette kan skabe til et miljø som de unge udsatte lidt nemmere kan falde ind i. Dernæst skal det ikke fornægtes at Dansk Supermarked er en stor virksomhed med ressourcer til at oprette en særskilt HR-afdeling, som forestår samarbejdet med kommunerne og som arbejder med kommunikationen internt i virksomheden, hvilket ligeledes er en stor opgave virksomheder - store som små.

Erfaringen fra Dansk Supermarked er ligeledes, at når de unge har et fritidsjob giver det dem en lærerig periode i forhold til, at kunne begå sig på arbejdsmarkedet. Erfaringen er, at den skoling som finder sted af de unge er meget konstruktiv for de unges videre færd på arbejdsmarkedet.

\subsubsection{Kilder}

Interview med Annette Vittrup, HR-partner, Dansk Supermarkeds HR-afdeling for mangfoldighed.

Interview med Tine Hedegård, Udviklingskonsulent, ADHD-foreningen.

Interview med Lillian Hjort Hansen, Jobkonsulent, Odense Jobcenter.

Interview med Christian Madsen, Nonfood Chef, Føtex Vesterbrogade København.

http://dansksupermarked.dk/news/ds-nomineret-til-people-prize/

http://vfsa.dk/files/VFSA/CSR_People_Prize/Nominerede\%202012/DGS\%20presse meddelelse \%20-\%20dansk\%20supermarked.pdf

Casen er bl.a. anbefalet af Virksomhedsforum for Socialt Ansvar (VFSA) og Social- og Integrationsministeriet, normineret til CSR People Prize 2012, samt tildelt integrationsprisen for årets arbejdsplads i 2012.

\subsection{High:five}

\subsubsection{Kort om initiativet}

Det igangværende projekt High:five blev etableret i 2006 af Virksomhedsforum for Socialt Ansvar (VFSA) med henblik på at hjælpe private virk- 
somheder og offentlige myndigheder med at etablere uddannelses- og arbejdspladser til udsatte unge, der er i fare for at blive marginaliseret som følge af kriminalitet. Formålet med High:five er at fungere som forbindelsesled mellem virksomheder, der ønsker at tage et socialt ansvar, og de centrale offentlige myndigheder, som kommer i kontakt med de unge: kriminalforsorgen, jobcentre, politi og andre interessenter. Endvidere er formålet med High:five, at ændre den generelle holdning til straffeattester, således at udsatte unge ikke oplever at blive unødigt stigmatiseret, hvilket skal bane vejen for en mere fordomsfri opfattelse af de unge som rehabiliterede medborgere, der har afsonet sin straf og som kan varetage en uddannelse eller et arbejde på lige fod med andre unge.

\subsubsection{Resultater}

High:five er opstået i erkendelsen af et behov for initiativer, der er med til tage udsatte unge ind og skabe en bedre overgang fra fængsler og ud i samfundet igen. Uddannelsesaftaler og virksomhedspraktik har vist sig at være særdeles effektivt i forhold til at mindske sandsynligheden for unges tilbagefald til kriminalitet. High:five har således en stor kriminalpræventiv effekt, især når det gælder unge, der kommer ind i High:five i forlængelse af en fængselsdom. Disse unge har en bedre selvforsørgelsesgrad og stor reduceret sandsynlighed for at falde tilbage i kriminalitet sammenlignet med unge, der ikke har modtaget High:fives indsats High:five tilkendegiver også at social mobilitet for målgruppen er et væsentligt aspekt af indsatsen. Det er ikke nok at skaffe jobs til de udsatte unge, de skal blive i dem og være medvirkende til at de skifter livsstil.

Konkret har High:five fra 2006 til 2009 etablerede 407 jobmatch mod en målsætning om 400. For 2010-2011 er der etableret 313 match hhv. 280 jobmatch og 33 uddannelsesmatch. High:fives nuværende driftsresultater er ca. 250 match om året. Set over hele perioden (2006 - d.d.) er der etableret mere end 1.000 match. $70 \%$ af de unge, der indgår i match, har skiftet livsstil. Succesraten er fra 2010 steget til ca. $85 \%$. High:five har således meget positive resultater. Endvidere er der stor tilfredshed med og opbakning til det arbejde High:five udfører fra alle samarbejdspartnerne blandt kommuner, kriminalforsorgen, politi og blandt virksomhederne og de unge. 


\subsubsection{Målgruppen}

Målgruppen for High:five er de udsatte unge mellem 15-30 år, altovervejende mænd og mange har fået en dom. Omkring $30 \%$ af dem har afsonet en dom (inkl. fodlænke), resten har enten en plettet straffeattest eller kan rubriceres som relativt umodne, som endnu ikke har lært konsekvensen af at begå kriminalitet. Størstedelen af dem har også haft misbrugsproblemer, hvilket ikke sjældent har været medvirkende til at fastholde dem i kriminalitet og de har som følge heraf fået en stor gæld. Mange har valgt en behandlingsdom. En af High:fives konsulenter anslår at ca. en tredjedel kommer fra kriminalforsorgen, en tredjedel fra kommunerne og den sidste tredjedel udgøres af unge, der selv opsøger High:five.

\subsubsection{Virksomhedernes rolle og gevinst}

High:five har konsulenter og projektledere rundt om i hele Danmark, som varetager den lokale indsats med virksomhedsnetværk og offentlige myndigheder. I 2013 består High:five af 19 medarbejdere. High:fives konsulenter arbejder dels med at screene og visitere de unge til virksomhederne og dels med at konsolidere, udbygge og forventningsafstemme med deres virksomhedsnetværk.

Med hensyn til visitationen af de unge, har High:five defineret nogle ufravigelige krav, der i høj grad er på virksomhedernes præmisser. Disse krav skal de unge leve op til for at fă et tilbud om hhv., virksomhedspraktik eller en uddannelsesplads hos en virksomhed. De unge skal være stoffri, have vilje og lyst til at arbejde, have en fast bopæl og have lagt kriminaliteten bag sig. Hos kriminalforsorgen afklares de unge via handleplanssamtaler med en socialrådgiver. Herefter kan socialrådgiveren efter aftale med den unge henvende sig til High:five, som efterfølgende indgår i en visitationssamtale med den indsatte eventuelt med deltagelse af socialrådgiveren og fængselsbetjenten. Her afklares den indsattes ønsker og faglige interesser for praktik/uddannelse, samtidig med at High:five gennemgår, om den unge opfylder kravene. Herved vil de sikre, at den unge virkelig er motiveret. Desuden forhører High:five sig hos kommunen og politiet, om den pågældende unge stadig "hænger ud" med de forkerte i sit gamle negative netværk. Ved en vellykket visitationssamtale forsøger High:fives konsulent at lave et passende match mellem den unge og en virksomhed i deres virksomhedsnetværk. Allerede her tydeliggøre de krav for den unge, bl.a. om at den unge har pligt til at møde på arbejde. Det er samtidig på dette stadie at High:five tager stilling til de unges gæld, som klart størstedelen har og gør det til en første prioritet at de unge sætter sig for at nedbringe den. Såfremt matchet er vellykket gennemgår kriminal- 
forsorgen arbejdsgiveren og laver et virksomhedsbesøg, hvorefter High:five primært overtager ansvaret for den løbende dialog og den opfølgende kontakt med den faste kontaktperson fra virksomheden.

Hvad angår virksomhedssamarbejdet forsøger High:five proaktivt at udvide med flere virksomheder, men de bliver også lejlighedsvist kontaktet af virksomheder, som giver dem besked om deres muligheder for at tage unge ind. High:fives rolle som bindeled er afgørende for at få virksomheder til at medvirke, fordi de kan aflaste dem for alt det administrative og praktiske med fx at indhente papirer for det offentlige og dermed gøre det mere overskueligt for især små virksomheder. High:fives konsulenter opretter desuden lokale følgegrupper, som bl.a. består af virksomhedsrepræsentanter, der herigennem får mulighed for at udveksle erfaringer og sparre med andre arbejdsgivere, som samarbejder med High:five. Endvidere tilbyder High:five mentorkurser til de virksomhedsrepræsentanter, der ønsker at medvirke i projektet og åbne deres virksomhed op for at deltage.

Virksomhedernes gevinst er særligt, at de får gratis professionel assistance fra High:five. Desuden får de en arbejdsom og loyal medarbejder, som er matchet til virksomheden og ønsker at være der. Endvidere ligger gevinsten i CSR-værdien, idet virksomhederne tager et socialt ansvar, hvilket både kan gøre de ansatte stolte over deres arbejdsplads og påskønnes af kunder og leverandører samt lokalmiljøet. Endelig viser High:fives erfaring, at der samlet set er plus på bundlinjen.

\subsubsection{Samarbejde med andre aktører}

High:five samarbejder med en lang række aktører. De samarbejder med alle kommuner og dermed alle jobcentre. Flere jobcentre oplever, at de via deres samarbejde med High:five har kunnet rykke nogle unge, som de ikke var i stand til at håndtere på egen hånd. High:fives samarbejde med kriminalforsorgen er også rigtig godt, og de har samarbejdet siden 2007. Noget af det, som bl.a. kriminalforsorgen og virksomhederne nævner, er, at High:five er virkelig gode til at være fleksible, hurtige og effektive, når de kontakter dem. Det gælder uanset, om det handler om en ledig læreplads, en screening af en ung eller blot rådgivning og faglig sparring om et igangværende praktikforløb. Det har stor betydning at High:five er til stede lokalt og kan besøge eksempelvis kriminalforsorgen, jobcentrene og virksomhederne fysisk, samt at de har faste kontaktpersoner hos alle parter. Dette er selve garanten for den koordinerede indsats. Kommunerne og kriminalforsorgen fremhæver især ansvarsfordelingen som en nøglefaktor, dvs. at de kender deres udsatte unge/indsatte og hele det lovgivningsmæssige grundlag, mens at 
High:five kender virksomhederne og deres behov. Dette vurderer virksomhederne også er essentielt, nemlig at High:five kender deres behov og er meget professionelle i deres screenings- og rådgivningsarbejde. Relationerne mellem hhv. kommuner, High:five, kriminalforsorgen og virksomheden er også vigtigt at bringe tæt ind på livet af den unge, fordi den unge herved bliver meget tættere knyttet til alle parter. Dette vurderer alle at være udslagsgivende for indsatsens succes.

\subsubsection{Finansiering}

High:five er på syvende år finansieret af satspuljemidler. Ved udgangen af 2012 fik High:five forlænget satspuljebevillingen for 2013 med 13 mio. DKK. Som i de øvrige år er der en direkte medfinansiering af High:five fra private virksomheder som er opgjort til ca. 1 mio. Hovedparten kommer fra Falck og Danfoss, der stiller kontor til rådighed for High:fives medarbejdere fire steder i Danmark. Derudover har der været en voksende delfinansiering fra virksomheder, der giver High:five favorable rabatter ud af et socialt engagement - fx på trykning af pjecer, møde- og konferencefaciliteter o.a.

\subsubsection{Forudsætninger for succes}

High:five kan ses som en slags indslusningsplatform, der forbinder de udsatte unges møde med de offentlige myndigheder med de rette virksomheder, fordi de med deres viden om virksomhedernes behov, kan sluse de rette unge ind og har ressourcer til at følge op. Det er en fordel med en sådan ekstern enhed, fordi de unge ikke oplever at High:five kommer "fra kommunen" eller "fra virksomheden", men at de hele tiden er i en støttende funktion. Samtidig er det væsentligt at det gode samarbejde bliver italesat som alles initiativ og dermed at alle vinder på denne samarbejdsindsats.

Den tætte, faste kontakt mellem alle parter er helt afgørende for succes. En mulig bekymring er dog, at det kræver meget viden fra High:fives side at navigere mellem alle parter, hvilket betyder at oplæringsperioden for konsulenterne er forholdsvis lang. Dette sætter projektets tidsbegrænsede støtte i perspektiv. High:five har behov for ressourcerne til at fungere eksternt som facilitator mellem virksomheder og de offentlige myndigheder og til at være repræsenteret lokalt.

Blandt alle parter synes der er at være en fælles forståelse af, at en god screening er afgørende for hvorvidt de unge klarer sig godt ude i virksomhederne, og derfor afspejler de gode resultater i betydeligt omfang High:fives screeningproces. Alle tilkendegiver at det afgørende, at den 
unge er motiveret og har indstillet sig mentalt på at forlade kriminaliteten og sit gamle liv. Dette giver genklang hos virksomhederne, som nogle gange ligefrem oplever, at disse unge er deres bedste medarbejdere, fordi de er motiverede og arbejdsomme og ikke tager deres job for givet.

\subsubsection{Udbredelse af indsatsen}

Fra High:fives side vurderes det, at systemet bag High:five godt kan overføres til andre lande, om ikke andet i tilpasset form. For at systemet kan fungere, er det væsentligt, at det er uafhængigt af såvel det offentlige som det private, så det kan målrette nogle ressourcer til at motivere omgivelserne til at beskæftige sig med og inkludere de udsatte unge. Der er selvstændige indsatser for at få udsatte unge i arbejde på både jobcenterniveau, i kriminalforsorgen og blandt enkelte virksomheder, men High:fives indsats viser, at der er et potentiale i at supplere opkvalificeringsindsatsen og skabe den koordinerede indsats. High:fives resultater afspejler, at der er skabt praktik- og lærerpladser, som ellers ikke ville være blevet skabt. I High:five har de unge altid en livline, fordi High:fives konsulenter kan kontaktes 24 timer i døgnet, hvilket også gælder virksomheder og det offentlige.

\subsubsection{Kilder}

Interview med Ole Hessel, projektleder, High:five.

Interview med Steen Edelberg Axelsen, Projektleder High:five Sjælland. Interview med Peter Lassen, virksomhedsrepræsentant, Fazer.

Interview med Rashad, ung I High:Five.

Interview med Lars Kure, kriminalforsorgen, beskæftigelsesleder i Statsfængslet ved Horserød.

Interview med Sussie Kjær, Socialrådgiver hos kriminalforsorgen ved Horserød.

http://highfive.net

Casen er anbefalet af: Styrelsen for Fastholdelse og Rekruttering og vinder af CSR People Prize i 2011. 


\subsection{Route 25}

\subsubsection{Kort om initiativet}

Route 25 er et projekt, som hjælper unge, der har brug for ekstra støtte, til at komme i gang med uddannelse eller job ved at tilbyde dem en mere koordineret og virksomhedsrettet indsats. Virksomhedsforum for Socialt Ansvar (VFSA) og Center for aktiv beskæftigelsesindsats (CABI) står bag projektet, som startede op i efteråret 2011 i et samarbejde med fire kommuner. Én kommune blev nødt til at trække sig, men de tre sidste kommuner; Ikast-Brande, Egedal og Odder Kommune, deltager fortsat.

De unge i projektet har mere eller mindre komplekse problemer, hvilket betyder, at én aktører har svært ved at løfte opgaverne alene. Problemet er ofte, at de udsatte unge har 10 forskellige handlingsplaner mv. fra de forskellige kommunale afdelinger, hvilket skaber forvirring og manglende succes med at få de unge tættere på arbejdsmarkedet. Projektet har således til formål at undersøge, hvordan man kan bruge en koordineret og tværfaglig indsats til at styrke de unge menneskers muligheder på arbejdsmarkedet. De involverede kommuner skal i projektet udvikle og afprøve en virksomhedsrettet og koordinerede indsats over for de unge i de tre kommuner. Dette sker ved at oprette ungeteams bestående af medarbejdere fra de aktører som typisk er i kontakt med målgruppen. Disse medarbejdere er kompetenceudviklet således, at de nemmere i praksis kan arbejde tværfagligt, og de kan sikre de udsatte unge en koordineret virk-somhedsrettet indsats.

\subsubsection{Resultater}

Status på projektet pr. januar 2013 er at 123 unge deltager i projektet. Heraf 49 som enten er eller har været i virksomhedspraktik, 23 som er begyndt på ordinær uddannelse og 12, som har fået ordinært job eller er i løntilskudsforløb.

Endvidere ses der tydelige resultater på den måde som medarbejderne i ungeteamet samarbejder og går til opgaven sammenlignet med før etableringen af ungeteamet og det tværfaglige samarbejde. Flere medarbejdere har fået et nyt og mere ens tankesæt. Eksempelvis mener langt flere af medarbejderne nu, at de unge - selvom det er unge med problemer ud over ledighed - med stor fordel kan komme i virksomhedspraktik. Endvidere ses virksomhederne i langt højere grad som en aktør, der kan bidrage til at bringe de unge tættere på arbejdsmarkedet. Ligeledes ses en forandring hos lederne i de tre kommuner, som i højere 
grad har erkendt behovet for tværfaglig samarbejde, hvis man skal undgå, at de unge "tabes mellem to stole". Endvidere er et resultat af projektet, et langt tættere samarbejde mellem de kommunale aktører og uddannelsesinstitutionerne. I forhold til de unge er et resultat af projektet, at flere unge kommer i forskellige tilbud og i praktik, hvilket sikrer at de ikke bliver parkeret eller tabt mellem to stole. Flere unge er kommet i virksomhedspraktik og i flere forskellige virksomhedspraktikker. Et jobcenter peger på at de har fået $80 \%$ I virksomhedspraktik, eller i uddannelse og beskæftigelse, hvilket er langt over landsgennemsnittet.

Endvidere peger både de unge og medarbejderne på, at projektet medvirker til at give de unge et fremtidsperspektiv. De får viden om, hvordan det er at være på en arbejdsplads - rollemodeller, selvtillid, og viden om deres egne evner.

\subsubsection{Målgruppe}

Målgruppen i Route 25 er unge mellem 15 og 30 år, som har problemer med at blive motiveret til, opnå eller fastholde uddannelse eller arbejde. De 15-17-årige er typisk unge, der er stoppet i folkeskolen uden eksamen eller er ikke kommet i gang med en ungdomsuddannelse, og som vurderes til at være i risiko for at komme på kontanthjælp. De 18 til 30åriges er typisk kontant- og starthjælpsmodtagere med problemer udover ledighed, der skal have ekstra støtte og hjælp for at bide sig fast på arbejdsmarkedet eller komme i gang med en uddannelse. Fælles for målgruppen er, at de typisk har indlæringsmæssige vanskeligheder, dårlige læse-, skrive- og regnekundskaber, problematisk social baggrund, sociale eller psykiske problemer og lettere misbrugsproblemer og mangler motivation, håb og viden om deres veje til uddannelse og job. Disse problemtyper stiller netop store krav til en koordineret og tværgående indsats i kommunerne.

\subsubsection{Virksomhedens rolle og gevinst}

De tre kommuner samarbejder på forskellig vis med de lokale virksomheder enten ved aktivt at opsøge dem, eller gennem mere integrerede virksomhedsnetværk. En kommune laver eksempelvis en brugerundersøgelse til mange lokale virksomheder, for at afdække hvad de har brug for af kompetencer og hvad de forventer af jobcenteret. De kommunale aktører skal i projektet bruge eksisterende værktøjer og lovgivning til at sikre et tæt samarbejde internt $\mathrm{i}$ kommunen og med lokale virksomheder. De lokale virksomheder kan gøre en forskel, fordi de unge i praksis kan få 
kendskab til arbejdslivet og få snust til forskellige brancher. Virksomhederne vil bl.a. gennem VFSA - åbne døren for de unge, som har brug for at gå en mere praktisk vej til uddannelse og arbejde.

Virksomhedskonsulenterne i jobcentrene er centrale aktører i Route 25. Det er dem, som laver det opsøgende arbejde i forhold til at finde virksomheder, som er åbne for at få de unge i virksomhedspraktik og samarbejde med virksomhederne, når der bliver etableret virksomhedspraktikker. Ligeledes er det virksomhedskonsulenterne, som søger at gøre de unge klar til at komme i virksomhedspraktik. De forklare dem, hvad det betyder at komme i virksomhedspraktik og tydeliggør de skånehensyn de har, fx at de ikke nødvendigvis skal være der 37 timer om ugen. Det handler for dem meget om at imødekomme de unge i forhold til den angst og de barrierer som de har.

I den virksomhedsopsøgende indsats, er der meget fokus på at matche den unge og virksomheden rigtigt. Dette indebærer også, at man i nogle tilfælde er villige til at afbryde praktikken, hvis man undervejs finder ud af at matchet ikke er rigtigt. Endvidere lægges der stor vægt på at engagere virksomheder via opfølgningssamtaler, deltagelse i virksomhedsmøder, information om muligheden for mentorskab for de unge mv.

I forbindelse med projektet er der blevet lavet specielle kompetenceudviklingsforløb for virksomhedskonsulenterne for at klæde dem ordentligt på til opgaven. I den forbindelse er der udviklet en progressionsmodel til virksomhedskonsulenterne, som de i samarbejde med repræsentanter fra virksomheder kan bruge til at sætte udviklingsmål for praktikanten samt løbende følge op på disse. Formålet er at få konsulenterne til at tænke tæt opfølgning ind fra starten samt resultatfokusering.

De virksomheder som deltager er alle typer af virksomheder. Alt fra de helt store til de helt små. Men de tre deltagne kommuner er kendetegnet ved at ligge i områder uden store virksomheder. Det er forskelligt hvor meget virksomhederne engagerer sig. Nogle virksomheder tager et større ansvar, fx tilbyder mentor i virksomheden. Men ellers er der også eksterne mentorer fra kommunen, som den unge kan få.

Virksomhedernes gevinst er både værdi- og CSR-mæssigt, samt en god, stabil arbejdskraft, som bliver på arbejdspladsen, når integrationen af den unge lykkedes succesfuldt.

\subsubsection{Samarbejde med aktører}

Samarbejdet mellem forskellige aktører er essensen i Route 25, da det handler om at skabe en koordineret og tværfaglig indsats for de udsatte unge. Koordineringen kræver netop samarbejde mellem en lang række 
aktører. I de enkelte kommunale ungeteams er sammensætningerne forskellige, men typisk indgår bl.a. medarbejdere fra jobcenteret, Ungdomsuddannelsesvejledningen (UU), børne- og familieafdelingen, socialserviceafdelingen (behandling, anbringelse, bostøtte mv.) samt misbrugsvejledere.

Ud over at samarbejde tæe med virksomhederne, som tager nogle af de unge i virksomhedspraktik, er der også et tæt samarbejde med uddannelsesinstitutionerne. UU har et tæt samarbejde med uddannelsesinstitutionerne omkring opfølgning på de unge under 25 år i uddannelsesforløb, herunder unge med behov for særligt støtte. Samarbejdet mellem ungeteamet og uddannelsesinstitutionerne handler fx om opfølgning på fraværdsskemaer, bevilling af mentor og iværksættelse af særligt tilrettelagt uddannelsesforløb. Der er således løbende dialogmøder med uddannelsesinstitutionerne.

\subsubsection{Finansiering}

Projektet er finansieret af satspuljemidler via Arbejdsmarkedsstyrelsen og løber i tre år fra 1. januar 2011 og indtil den 30. juni 2014.

\subsubsection{Forudsætninger for succes}

En række forskellige forudsætninger er centrale for, at et projekt som Route 25 lykkedes:

- Tværfaglighed og helhedsorientering ses som en forudsætning for at kunne bringe unge tættere på arbejdsmarkedet. Essensen i indsatsen er at slippe monofagligheden og styrke tværfagligheden, og tænke i en helhedsorienteret indsats selvom den går på tværs af forvaltninger og fagligheder. I mange år har man talt om tværfaglighed, og man har ofte siddet tværfagligt men fortsat arbejdet mono-fagligt. Det er altså vigtigt, at man forstår at arbejde tværfagligt, ikke er det samme som at sætte sig om et bord sammen.

- Fælles forståelse og tæt samarbejde i ungeteamet. Det er vigtigt, at alle medarbejderne i ungeteamet dedikerer sig til at tro på, at virksomhederne er en mulig aktør for alle borgere, herunder også udsatte unge og i fællesskab arbejder for den virksomhedsrettede indsats. Endvidere er det vigtigt, at alle i ungeteamet fokuserer på job og uddannelse som målet for den unge. Det er generelt vigtigt, at man sikrer, at alle medarbejdere føler ejerskab. Vejen til dette er dialog, koordinering og videndeling mellem faglighederne, fx at der 
orienteres om lovene - beskæftigelseslovgivningen og social service lovgivningen, samt kompetenceudvikling i ungeteamet.

- Tæt samarbejde mellem jobcenteret og virksomhederne. Det er vigtigt for virksomhederne med tæt samarbejde med Jobcenteret, herunder at jobcenteret tilbyder én indgang til virksomhederne - én primær kontaktperson, som også kan tage sig af den unge, hvis der opstår problemer eller lignende og løbende følger op på den unges trivsel og progression på virksomheden.

- Endvidere skal virksomhederne tilbydes matchning, dvs. at der søges unge til virksomheder, som kan anvendes til de funktioner som de har brug for i virksomheden.

- Ved arbejdsprøvning høres virksomheden om de vil deltage i at afdække hvad den unge kan. Her tydeliggøres det at forventningen ikke er ansættelse af den unge. Dvs. forventningsafstemning er meget centralt. I den forbindelse er det vigtigt, at jobkonsulenten er ærlig over for virksomheden omkring alle forhold omkring den unge, således at virksomheden er forberedt bedst muligt. Det er ligeledes vigtigt at jobkonsulenten stiller krav til de unge og respektere de unges udfordringer samt at jobkonsulenten løbende følger op på den unges trivsel, såvel for virksomhedens som den unges skyld. Jobkonsulenten har således en central rolle i indsatsen og dennes holdning, indstilling og tilgang er derfor særlig central.

- Ikke for store omkostninger for virksomhederne. Det er meget væsentligt, at det er en nuludgift for virksomheden, særligt når der er de udsatte unge, som kan kærve flere ressourcer at integrere. Virksomhederne skal i forvejen lægge ressourcer i oplæring mv., hvorfor det er vigtigt at minimere ekstra tid og ressourcer for dem. Dette indebærer bl.a. at minimere virksomhedens administrationsomkostninger på etableringen af virksomhedspraktikken.

- Politisk ledelse og prioritering. Det er vigtigt at opgaven bliver prioriteret, og at der fra ledelsens side i de kommunale forvaltninger afsættes de nødvendige ressourcer til det.

\subsubsection{Udbredelse af initiativet}

Projektholderne forventer, at de ud fra dette projekt kan sætte nogle modeller for, hvordan man kan arbejde med projektet i andre kommuner i forskellig skala. Planen er, at der skal laves et inspirationskatalog til alle landets kommuner til efteråret. Projektets forventes således godt at kunne udbredes til andre kommuner i landet. 
Et særkende ved en del danske virksomheder er deres sociale engagement - at de lægger stor vægt på et godt CSR-image. Ligeledes er der en national kontekst med store udviklingsmidler som gives til sådanne projekter (her satspuljemidler) samt støtten som ydes til virksomhedspraktik. Alligevel kan man på tværs af de nationale grænser godt hente inspiration fra projektet.

\subsubsection{Kilder}

Interview med Camilla Høholt Schmidt, Projektleder CABI.

Interview med Dorthe Wirring, Projektkoordinator/sagsbehandler, Odder Jobcenter. Interview med Sanja Saric, Teamleder, Egedal Jobcenter.

Interview med Heidi Klumbach, Projektkoordinator, Ikast-Brande Jobcenter.

Interview med John Lundgårds Hansen, Jobkonsulent, Odder Jobcenter.

Interview med Pernille Sofie Dam, ung I Praktik i JC Tegn og Byg.

www.route $25 . \mathrm{dk}$

Anbefalet af: Virksomhedsforum for Socialt Ansvar (VFSA), Beskæftigelsesregion Midtjylland.

\subsection{Grundfos}

Grundfos' sociale engagement er en integreret del af virksomhedens værdigrundlag og af virksomhedsdriften. Grundfos har en lang tradition for at tage aktivt del i lokalsamfundet. Allerede i 1968 oprettede Grundfos sit første beskyttede vækststed, som var målrettet udviklingshæmmede, med svag tilknytning til arbejdsmarkedet. I dag er målgruppen for Grundfos' sociale aktiviteter langt bredere og antallet af værksteder (i dag kaldet fleks-værksteder) er steget til seks. Desuden er der blevet oprettet en afdeling for Grundfos' sociale engagement, som er ansvarlig for en række aktiviteter, der har til formål at forebygge udstødelse af medarbejdere og integration af socialt udsatte grupper i virksomheden.

\subsubsection{Kort om initiativet}

Grundfos har en række aktiviteter, der sigter på at integrere socialt udsatte grupper på arbejdsmarkedet, herunder udsatte unge. Aktiviteterne har både form af projekter og tiltag, som er en del af driften. Et interessant projekt er et tredelt projekt kaldet kontanthjælps-, lærlinge- og flygtningeprojektet, der retter sig mod hver sin målgruppe. Disse projekter er en del af projektet "Virksomhedens sociale engagement", som er 
finansieret af Socialministeriet. Projektet løb fra 2006-2008, og der er foretaget en første evaluering. Projekterne er fortsat dybt relevante og aktuelle i Grundfos, da virksomheden har gjort projekterne til en integreret del af driften baseret på deres positive erfaringer. Formålet med projektet og videreførelsen er overordnet set at udvikle metoder som private og offentlige arbejdsgivere kan anvende i bestræbelserne på at opnå et mere fleksibelt og rummeligt arbejdsmarked. Videre er formålet at rekruttere de unge til ordinær beskæftigelse.

\subsubsection{Resultater}

Siden 1968 er antallet af fleks-værksteder i Grundfos øget fra ét til seks, og målgruppen er udvidet markant. Grundfos har ca. 120 medarbejdere ansat på fleks-værkstederne i fleksjob- og løntilskudsstillinger, svarende til ca. 3 $\%$ af de danske medarbejdere. Op mod 85 personer er i afklaringsforløb i værkstederne. De tre projekter, ligesom deres øvrige sociale indsatser, er blevet en integreret del af deres koncernpolitik, og de lægger vægt på, at ansættelser skal være til gavn for den enkelte og for virksomheden.

Grundfos' konkrete erfaringer med de omtalte projekter er gode. Ud af de ti kontanthjælpsmodtagere, der gennemførte kontanthjælpsprojektet, er ca. syv af personerne i dag ansat i ordinært arbejde på virksomheden, mens yderligere én person er blevet ansat i fleksjob. Ca. halvdelen af de flygtninge og indvandrere, der gennemførte integrationsprojektet, er efterfølgende blevet fastansat på virksomheden. Erfaringerne fra lærlingeprojektet er også gode. Erfaringerne viser således, at nye medarbejdere ansættes både i ordinære job og fleksjob.

\subsubsection{Målgruppe}

Målgruppen for projekterne og det sociale arbejde i Grundfos generelt er bred. Det omfatter både langvarige kontanthjælpsmodtagere, unge kriminelle, unge der ikke på egen hånd kan gennemføre en erhvervsuddannelse, misbrugere, samt flygtninge/indvandrere. De forskellige grupperinger har forskellige barrierer, som vanskeligg ør, at de kan varetage et job eller tage en uddannelse. Grundfos har fx erfaret, at de unge i lærlingeprojektet har haft de største indlæringsmæssige vanskeligheder, mens de unge i flygtningeprojektet har haft de største familiemæssige/sociale problemer, hvilket har krævet forskellige indsatser. 


\subsubsection{Virksomhedens rolle og gevinst}

Noget af det unikke ved Grundfos' sociale indsats er, at de har seks fleksværksteder, der hver er tilknyttet en produktionsafdeling. Her er arbejdsopgaverne og -tempoet langsommere end i den almindelige produktion, men derudover tilstræbes samme vilkår som i resten af virksomheden. Fleks-værkstederne fungerer som underleverandører til den almindelige produktion. Det giver gode muligheder for introduktions- og indslusningsforløb til udsatte unge, hvorfor de fleste udsatte unge starter i en introduktionsstilling her. Målet med introduktionsperioden på værksteder er afklaring og opkvalificering af de unges kompetencer, og forløbene varierer fra to uger til flere år for andre, hvilket tilpasses efter individuelle behov. Efter introduktionsperioden i et af fleks-værkstedet overgår størstedelen af projektdeltagerne til virksomhedens almindelige produktion.

Fælles for Grundfos sociale indsatser overfor ledige, herunder udsatte unge, er at der er en række faser:

- Visitation og rundbordssamtale: For at sikre en grundig visitation af den udsatte unge, bør der være en samtale mellem den ledige, kontaktpersonen fra Grundfos og jobcentret (og evt. sprogcenter). Ved lærlinge medvirker erhvervsskolen også i visitationen.

Visitationen skal også sikre et godt match mellem den unge og virksomhedens opgaver. Fokus er på at få synliggjort hvad de unge er gode til, så de bliver mere motiveret. Her snakkes bl.a. om hvornår og hvordan de skal starte (skånehensyn, socialmentor fra kommunen som fx hjælper dem med at komme op om morgenen, virksomhedsmentor som på virksomheden hjælper dem mv.).

- Indslusning: Introduktion, afklaring og oplæring i fleks-værkstederne og efterfølgende i en af virksomhedens produktionsgrupper. Alle får tildelt en mentor i fleks-værkstedet og senere en kontaktperson i produktionsgruppen.

- Løbende opfølgning: Indebærer bl.a. vejledningssamtaler mellem personen og mentoren, hvor der fastsættes personlige mål. Derudover afholdes der opfølgningssamtaler mellem personen, jobcenteret og virksomheden hver tredje måned. Hvis en uddannelsesinstitution indgår i forløbet, deltager den også i opfølgningssamtalerne.

- Inkludering: Målet er, at den ledige bliver ansat på Grundfos eller en anden virksomhed. Personen har en kontaktperson i produktionen på Grundfos og som oftest en tilknyttet mentor.

Kontanthjælpsmodtagere, flygtninge og indvandrere gennemgår en periode med løntilskud og tid til supplerende kurser og oplæring. Målet for lærlinge er at gennemføre en erhvervsuddannelse. 
Grundfos udviser en stor villighed til at ansætte de unge, hvor der er brug for deres kompetencer og arbejdskraft. Deres erfaringer viser, at deres produktion kan opdeles i mindre enheder, hvilket gør at de har et godt udgangspunkt for at tage de unge ind, hvilket resultaterne også viser, da de både bliver ansat på ordinære og særlige vilkår. Grundfos gør opmærksom på, at tiltagene er til gavn for både de nye medarbejdere, virksomheden og lokalsamfundet.

Grundfos sociale engagement betyder, at der lægges en del ressourcer i dialog og dokumentation i forhold til kommuner og den enkelte medarbejder. Udover administrative ansatte har Grundfos 1-2 socialrådgivere ansat, som hjælper til med de mange ansatte på særlige omstændigheder. Alligevel er ansættelse, administration og ledelse af 125 medarbejdere ansat på særlige vilkår ikke en væsentlig ekstraomkostning for Grundfos. Det sætter på flere måder et positivt præg på mange dele af virksomheden. At måle detaljeret på den samlede økonomi er ikke helt enkelt ifølge ledelsen, som har indtryk af at omkostninger og fordele generelt balancerer fint. Så selvom det giver ekstra omkostninger, giver det sociale engagement indtægter på et kvalitativt parameter godt omdømme og image og nemmere rekruttering.

\subsubsection{Samarbejde med andre aktører}

Grundfos samarbejder med en bred vifte af aktører. I de tre projekter samarbejder de med jobcentrene i Viborg, Silkeborg, Randers, Favrskov og Vesthimmerland. Både på jobcentrene og på Grundfos er der udpeget faste kontaktpersoner i samarbejdet.

Ligeledes samarbejder de med de tilknyttede sprogcentre i enkelte tilfælde, hvis de unge fx har sproglige problemer. Særskilt for lærlingeprojekter samarbejder de også med en erhvervsskole i regionen.

\subsubsection{Finansiering}

De ressourcer som Grundfos bruger på oprettelse af fleks-værksteder, kontaktpersoner mv. samt på de projekter de engagerer sig $\mathrm{i}$, finansierer Grundfos selv. Men Grundfos betaler, som andre danske virksomheder, ikke løn under en virksomhedspraktik for en udsat ung, da den denne får en ydelse fra a-kassen eller kommunen. 


\subsubsection{Forudsætninger for succes}

- Fleks-værkstederne spiller en betydningsfuld rolle som base i introduktionsperioden, fordi der er ekspertise og tid til rådighed til at afklare, introducere og oplære den unge. Dog må de unge ikke blive for længe her, så det får karakter af "opbevaring".

- Faste kontaktpersoner. Det er vigtigt, at der er faste kontaktpersoner, som står både for kontakten til samarbejdspartnere og den personlige opfølgning. Kontaktpersonen på virksomheden bidrager til, at praktikanten integreres socialt på virksomheder, ligesom de medvirker til oplæring af praktikanten. Ligeledes er det vigtigt, at der er faste kontaktpersoner hos jobcenteret og andre aktører der samarbejdes med, således at virksomheden kan kontakte disse hvis der opstår nogle problematikker med den unge, som er uden for virksomhedens rækkevidde.

- Koordination og samarbejde. Det vigtigt, at der samarbejdes og koordineres både internt og eksternt i forhold til den enkelte praktikant. Internt skal der koordineres og samarbejdes mellem de forskellige afdelinger i virksomheden og eksternt skal der samarbejdes og koordineres med myndigheder og uddannelsesinstitutioner. Dette sikrer en mere helhedsorienteret indsats for den unge, samt at den unge ikke kan spille de forskellige aktører ud mod hinanden.

- Opfølgning. Det er vigtigt, at der følges op på den enkelte udsatte i praktikken, og at der sættes fokus på dels den enkelte persons situation, og dels på virksomhedens krav til kommende medarbejdere.

\subsubsection{Udbredelse af initiativet}

Grundfos' fleks-værksteder giver unik mulighed for indslusning af de unge, hvilket er en mulighed som ikke alle virksomheder tilsvarende har. Men Grundfos' indstilling og tænkning omkring inddragelsen af de unge kan andre tage ved lære af. Man kan overveje om arbejdet i en virksomhed på en tilsvarende måde kan "opdeles" så udsatte unge med lavere kvalifikationer kan agere underleverandører til andre produktionsled eller ift. services eller lign. Virksomhedens størrelse giver den også mere gunstige betingelser, men bør ikke per se være en hæmsko for andre. 


\subsubsection{Kilder}

Interview med Mogens Lindhard, CSR ansvarlig, Grundfos.

Interview med Arne Nygaard, Produktionsleder, Grundfos.

Interview med Lars Møgelbjerg, mentor, Grundfos.

Interview med Alex Sørensen, ung, Grundfos.

Interview med Arne Bjørn, jobkonsulent, Viborg Jobcenter.

www.grundfos.dk

http://www.vidensnetvaerket.dk/om-virksomheder/grundfos-2013-godeerfaringer-med-afklaring-og-opkvalifi-cering-af-udsatte-grupper

Casen er bl.a. anbefalet af Dansk Industri (DI) og www.vidennetvaerket.dk 



\section{De norske cases}

\subsection{Bøy av - Fra kaos til fagbrev}

\subsubsection{Kort om initiativet}

Bøy av-prosjektet startet i 2008 og ble avsluttet i 2010. Bakgrunnen for prosjektet var at bedriften trengte tilgang på relevant arbeidskraft, blant annet i mangel av lærlinger. Bedriften begynte på bakgrunn av dette å tenke nytt rundt rekruttering. Basert på bedriftens erfaring med hvem som var gode arbeidere i bedriftens produksjon, ønsket de å komme i kontakt med unge som ikke hadde fagbrev.

Bedriften hadde på tidspunktet prosjektet ble satt ut i livet rundt 120 ansatte, hvorav 30 til 40 av disse var innleid utenlandsk arbeidskraft. De utenlandske hadde fått jobb på bakgrunn av at de kunne dokumentere relevant praktiske kvalifikasjoner, ikke på bakgrunn av om de hadde formell dokumentasjon på fullførte utdanninger og at de hadde bestått matematikk, hadde nok timer i gym og så videre. Det ble ut fra dette stilt spørsmål om hvorfor man ikke også kunne rekruttere norsk arbeidskraft ut fra tilsvarende kriterier, der man ikke kun baserte ansettelser på fullført og bestått videregående opplæring. Oppstarterne av prosjektet hadde også erfaring med at mange unge som tradisjonelt blir sett på som skoletapere ofte blomstrer når de kommer inn i et godt arbeidsmiljø, får lære gjennom praksis og de gis en ny sjanse. En viktig grunntanke i hele prosjektet var inkluderende arbeidsliv.

NAV ønsket å prøve ut arbeidet etter Supportet Employmentperspektivet (SE), hvor man før rekruttering, foretar en grundig kartlegging av arbeidsgiver før rekruttering og følger opp arbeidsgiver etter ansettelse. Dette skal medvirke til at det å være i arbeid skal oppfattes som meningsfullt og at den enkelte ikke skal oppleve det å få seg jobb (uten fagopplæringskontrakter) som stigmatiserende eller ekstra belastende. 
Hensikten med prosjektet var å undersøke om et godt arbeidsmiljø er det som skal til for å inkludere ungdom som har falt utenfor skole og arbeidsliv. Målet var i tråd med IA-avtalenes mål: ${ }^{3}$

- $\AA$ A forebygge og redusere sykefravær, styrke jobbnærværet og bedre arbeidsmiljøet, samt hindre utstøting fra og frafall i arbeidslivet.

- Tilsette personer med nedsatt arbeidsevne.

- Prosjektets mål var å forhindre utstøting fra og frafall i arbeidslivet, og å definere inkluderingsbegrepet til noe mer enn sykefravær.

- Resultat.

- Av sju utvalgte prosjektdeltakere, oppnådde fire fagbrev og er i dag fast ansatt. De resterende avsluttet deltakelse underveis.

\subsubsection{Resultat}

Av sju utvalgte prosjektdeltakere, oppnådde fire fagbrev og er i dag fast ansatt. De resterende avsluttet deltakelse underveis. Gjennom prosjektet fikk de unge opplæring gjennom praktisk arbeid, slik at de etter hvert var i stand til å ta fagprøve. I tillegg til den rent konkrete faglige opplæringen, fikk de unge også opplæring i hva det vil si å være i arbeid og hva som forventes av dem i arbeidslivet. Det ble også lagt vekt på personlig utvikling. Deltakerne hadde behov for generell kunnskap om hvordan ting fungerer i samfunnet. Mange kommer fra hjem der de ikke lærer dette. Prosjektdeltakerne ble også veiledet og korrigert undervis i forhold til atferd på arbeidsplassen og lignende, og de fikk direkte tilbakemelding på uakseptabel oppførsel. De ble også utfordret på å tenke rundt hvor de ville være om noen år, hva som ville være konsekvensene av om de ikke fullførte prosjektet og de ble realitetsorientert rundt egen situasjon og hva de selv måtte bidra med. Dette ble tatt godt imot av de unge. De ble tatt på alvor, sett og hørt.

Alt i alt kan man si at prosjektet ga positive utslag for den enkelte, ved at de fikk en ny sjanse, kom seg ut av NAV og fikk livet sitt på rett kjøl. Det var også en gevinst for bedriften, ved at de fikk tilgang til arbeidskraft, og gjerne trofaste arbeidstakere utover det som ellers er normalt, da bedriftens engasjement på mange måter skapte et ekstra lojalitetsforhold mellom arbeidstaker og arbeidsgiver. Det hadde også en

\footnotetext{
${ }^{3}$ IA er en forkortelse "inkluderende arbeidsliv". IA-avtalen har sitt utspring i intensjonsavtalen om et mer inkluderende arbeidsliv, inngått mellom partene $\mathrm{i}$ arbeidslivet og regjeringen:

http://www.nav.no/Arbeid/Inkluderende+arbeidsliv/Hva+er+IA
} 
samfunnsøkonomisk gevinst ved at de unge ikke lenger trengte støtte fra NAV, men at de nå var bidragsytere i samfunnet, både gjennom å være i jobb og også ved at de ikke lenger hadde rusutfordringer, drev med kriminalitet og så videre.

\subsubsection{Målgruppe}

Bedriften tok kontakt med det lokale NAV-kontoret og ba dem om å plukke ut noen kandidater som kunne være aktuelle kandidater til prosjektet. Kriteriene for utvelgelse var at det var snakk om unge personer som hadde droppet ut av fagutdanning på videregående opplæringsnivå innen industrirørlegging/sveising. Personene måtte ikke være for tungt rusbelastet og de måtte ha et snev av motivasjon for å ville ønske fagbrev og være i arbeid. Sju gutter ble plukket ut til å være med i prosjektet.

Disse sju kandidatene ble plukket ut på bakgrunn av et ordinært jobbintervju. Guttene kom fra ulike miljøer og hadde ulike utfordringer, som at de kom fra en barnevernsinstitusjon, var domfelt, hadde rusproblemer, hadde diagnosen ADHD, manglet formell utdanning, langtidsledige, korte engasjement hos ulike arbeidsgivere, angst og sosiale problemer.

\subsubsection{Virksomhetens rolle og gevinst}

Aker Piping Technology har vært sentrale. De deltok i prosjektgruppen og hadde en viktig rolle i å på bakgrunn av kartleggingen av den enkelte og bygge videre på dette, med mål om å utvikle den enkelte slik at de kunne oppnå fullført videregående opplæring/fagbrev.

Utover at bedriften hadde behov for arbeidskraft, ønsket de også å ta et samfunnsansvar. Prosjektet har også bedret bedriftens omdømme og har gjort det lettere å få tak i arbeidskraft. Før måtte bedriften nesten trygle unge om å søke læreplass i bedriften. Etter prosjektet, er det nå 40-50 som ønsker læreplass å jobbe i bedriften. Prosjektet førte til at bedriften fikk et godt omdømme for å ha godt arbeidsmiljø og for å ta vare på sine ansatte.

\subsubsection{Samarbeid mellom aktører}

Prosjektgruppen bestod av representanter fra NHO, Opplæringskontoret, Verdal kommune, NAV Verdal, NAV Arbeidslivssenter, Aker Piping Technology og Nord-Trøndelag fylkeskommune. I tillegg var det opprettet en arbeidsgruppe bestående av tre representanter fra Aker 
Piping Technology, Opplæringskontoret/Opplæringskontoret for teknologifag (OTEK) og NAV.

I intervjuene vi har gjennomført, ble noen aktører særlig trukket frem som sentrale aktører i prosjektet, utover bedriftens engasjement. Dette var fylkeskommunen, som ansvarlig for videregående opplæring, Opplæringskontoret/Opplæringskontoret for teknologifag (OTEK) og NAV. Fylkeskommunen bidra med økonomiske midler og kompetanse om de utdanningsmessige forholdene. Opplæringskontoret sørget for å kartlegge den enkelte prosjektdeltakers situasjon og lagde individuelle oppfølgingsplaner for hver av personene som deltok i prosjektet. Opplæringskontoret, sammen med NAV, blir også trukket særlig frem fordi de var villige til å endre sine byråkratiske retningslinjer og for at de ønsket å se på problemstillingen ved at unge faller utenfor arbeidslivet gjennom nye metoder/virkemidler.

\subsubsection{Finansiering}

Utover tiden og ressursene bedriften selv brukte, ble prosjektet finansiert gjennom at bedriften fikk ordinære satser for å ta inn lærekandidater og lærlinger, samt at de fikk et tilskudd, som Nord-Trøndelag fylkeskommune hadde opprettet til å gi bedrifter for å ta inn unge som lærekandidater som stod utenfor arbeidslivet. Tilskuddet var på 50000 NOK per lærekandidat. I tillegg gikk NAV og NHO gikk inn med 500000 hver, samt at Norsk Industri bidro med 50000 NOK til opplæring.

\subsubsection{Forutsetninger for suksess}

På spørsmål om hvilke suksesskriterier som kan trekkes frem for at et slikt prosjekt skal være vellykket nevnes følgende i intervjuene vi har gjennomført:

- I bunnen må det ligge en grunnleggende tro på at alle er gode til noe og at dette kan utvikles og bygges videre på.

- De unge må behandles og inkluderes på arbeidsplassen på linje med andre ansatte.

- Arbeidsmiljø og personalpolitikk på arbeidsplassen. I dette prosjektet gjorde bedriften et grundig forarbeid med å informere de ansatte om hva prosjektet innebar og at det var viktig at de ansatte måtte ta godt imot prosjektdeltakerne og gi dem god opplæring.

- Helt avhengig av ildsjeler, da man i Norge ikke har god nok struktur eller kultur for å iverksette slike prosjekter. 
- At bedriften gjør et grundig arbeid med å involvere øvrige ansatte og at alle ansatte er motiverte til å bidra.

- At bedriften er godt egnet til å ta imot unge med utfordringer. Bedriften må ha ansvarlige personer som er i stand til å skape rammer på arbeidsplassen som gjør at de unge føler seg velkommen og trives. De ansvarlige i bedriften må også være i stand til å motivere og følge opp de unge på en skikkelig måte og gi dem tilbakemelding og troen på seg selv.

- Prosjektet må ha en plan. Det kreves at ulike aktører, med forskjellig relevant kompetanse er involvert. De unge det her er snakk om, har ofte svært sammensatte utfordringer, som ikke bare en aktør kan være med å løse alene. Hvis den unge skal klare å komme seg i jobb og leve opp til de kravene som stilles, kan det for eksempel hende at de unge trenger hjelp til å komme seg ut av kriminalitet, de trenger hjelp med rusproblemer, de trenger et sted å bo og så videre.

- Finansiering utover det bedriftene bidrar med av tid og ressurser.

\subsubsection{Utbredelse av initiativet}

Prosjektet er avsluttet, men lever i praksis videre ved at bedriften har endret sin ansettelsespolitikk. Per i dag er det ingen planer om å starte et lignende prosjekt på nytt, men Aker Piping Technology er en IAbedrift, med mål om å ta inn en ungdom per år med samme bakgrunn som de som var med i Bøy av-prosjektet.

Verdal kommunen har senere etablert en tilsvarende ordning, etter mal fra Bøy av-prosjektet, for å fă tilgang til arbeidskraft med helsefagskompetanse.

Prosjektet har også blitt tatt svært godt imot blant politikere og kunder av bedriften, for at bedriften har tatt et samfunnsansvar. Bedriften har også i etterkant av prosjektet blitt kontaktet av skoler, NAV, foreldre med flere, med forespørsel om å ta inn flere unge.

\subsubsection{Kilder}

Sidsel Dahl Bjørgvik, tidligere ansatt ved Aker Piping Technology. Nå ansatt ved NAV. Nils Magnus Lyngstad, Aker Piping Technology. Per-Kristian Storstad, Nord-Trøndelag fylkeskommune. Har også fått bekreftet prosjektet av Helge Myrstad NAV. 
Prosjektdeltaker (anonym).

Bøy av - Fra kaos til fagbrev. Sluttrapport.4

DAMVAD ble først oppmerksom på dette prosjektet gjennom www. idebanken.no.

\subsection{TAFU (TAFU Rogaland)}

\subsubsection{Kort om initiativet}

Prosjektet TAFU - Tilbakeføring gjennom arbeid, fritid og utdnning er et nasjonalt prosjekt som per i dag tilbys i Rogaland og Tromsø. Informasjonen som her fremstilles på bakgrunn av intervjuer eller skriftlig informasjon fra sentrale aktører, tar utgangspunkt i TAFU Rogaland og TAFU nasjonalt, ved Fylkesmannen i Hordaland som har det nasjonale ansvaret for styring og utvikling av prosjektet.

Kunnskapsdepartementet iverksatte TAFU-prosjektet i 2009. Prosjektperioden utløper i desember 2013, men det vurderes om prosjektet skal videreføres. Tanken bak var at TAFU-prosjektet skulle imøtekomme prosjektdeltakernes mangel på utdanning, og videre øke muligheten til å få jobb.

Prosjektets utgangspunkt var å skulle prøve ut en ordning tilsvarende Krami-prosjekt i Sverige. ${ }^{5}$ Dette innebærer blant annet å få til et tverrgående samarbeid mellom flere instanser for å hjelpe straffedømte ut $\mathrm{i}$ arbeid. Det overordnede målet er å hjelpe straffedømte i alderen 18 til 40 år til å få seg utdanning og å komme i jobb.

Prosjektets motivasjon dekker et sammensatt behov. For justissektorens del handler det blant annet om å gi straffedømte utdanning og mulighet til jobb for å minske sannsynligheten for tilbakefall. For NAV og kommunene gjelder det hovedsakelig om å gjøre stønadsmottakere til bidragsytere. Ved å kjede sin innsats, for eksempel gi en person som har vært i rusbehandling bedre boforhold og praksis eller arbeid, får innsatsen totalt sett bedre effekt. Fylkeskommunene igjen har mer et rent utdanningsperspektiv, da de ønsker at flest mulig skal gjennomføre videregående opplæring eller tilsvarende.

\footnotetext{
${ }^{4}$ http://www.nho.no/getfile.php/1-0\%20Sluttrapport\%20B\%C3\%B8y\%20Av\%20 $\% 20$ fra $\% 20$ kaos $\% 20$ til $\% 20$ fagbrev.pdf

${ }^{5}$ www.krami.se
} 
I intervjuene vi har gjennomført ble det også lagt vekt på at prosjektet handler om å gi folk mulighet til å gjøre noe positivt med livet sitt. Utgangspunktet er at alle i målgruppen for prosjektet kan klare å gjennomføre prosjektet og få seg en utdanning og jobb. Det krever på den andre siden at aktørene i prosjektet gjør det de sier de skal gjøre for å hjelpe til. Det tas ikke utgangspunkt i hvem man på forhånd tror og ikke tror kan være egnet for prosjektet, da dette av erfaring ofte viser seg å være feil. Det er samtidig slik at kursdeltakerne har ulike og sammensatte utfordringer. Den mest synlige utfordringen er rusmisbruk/tilbakefall til rusmisbruk.

\subsubsection{Resultater}

Ingen av de vi intervjuet kunne på stående fot si noe om resultatene fra prosjektet på det tidspunktet intervjuene ble gjennomført (juni/juli 2013). DAMVAD har imidlertid fått ettersendt evalueringen av prosjektet. Evalueringen var ikke tilgjengelig da hoveddelen av datainnhentingen pågikk.

Gjennom intervjuet med representanten fra Baker Hughes oppgis den største gevinsten ved å ansette personer fra TAFU-prosjektet at de som tas inn tilfører bedriften en verdi ved at de leverer en god arbeidsinnsats.

I evalueringen av TAFU-prosjektet konkluderes det med at " (...) TAFU lønner seg, både fra en pessimistisk samfunnøkonomisk analyse, men også vurdert ut fra et normativt medmenneskelig ståsted."6 Det gis også inntrykk av at de involverte aktørene i prosjektet alt i alt er fornøyd med prosjektet, herunder prosjektdeltakerne.

\section{Erfaringen til en av prosjektdeltakerne}

Vi har intervjuet en tidligere prosjektdeltaker som nå er i fast jobb som resultat av TAFU-prosjektet. Vedkommende har tidligere drevet med kriminalitet, hatt rusproblemer og vært straffedømt, men har også tidligere arbeidserfaring og utdanning innen fag- og yrkesopplæring.

På tidspunktet da den tidligere kursdeltakeren kom inn i TAFUprosjektet, var han ikke i fengsel, men gikk jevnlig til samtaler til en fast person som del av rusverntjenesten. TAFU Rogaland kom dit og presenterte seg selv, og kontaktpersonen til vårt intervjuobjekt satte han da i kontakt med TAFU.

\footnotetext{
${ }^{6}$ Neumann, Cecilie Basberg og Karen-Sofie Pettersen (2013): Tilbakeføringsgarantien i praksis. Evaluering av prosjektet TAFU - Tilbakeføring gjennom arbeid, fritid og utdanning- AFI-rapport 11/2013.
} 
Etter to intervju hos TAFU Rogaland begynte personen på TAFUs kurs. Bare noen uker etter kurset var avsluttet, begynte han i jobb. Etter fire måneders praksisplass ble han tilbudt seks måneder prøvetid og dette endte i fast jobb.

Personen vi har intervjuet sier at for han var kursene viktige for å komme inn i rutiner, for eksempel ved at det ble forventet at han var rusfri og at han kom dit han skulle når han skulle. Videre var kurset viktig for å få troen på seg selv og troen på og viljen til at han skulle klare å få orden på livet sitt og å få jobb.

Et annet moment var at han fikk hjelp til å takle de utfordringene han hadde med angst og depresjon. Bare det å gjennom kurset måtte forholde seg til mange ukjente folk var en del av det å komme tilbake til et normalt liv og det å forberede seg til arbeidslivet.

Da han kom i jobb var det kun noen få personer som kjente til fortiden hans. De aller fleste trodde at han var en ordinær NAV-bruker. Det opplevdes som godt å være "anonym" for å ikke bli stigmatisert. Det mest positive ved å komme i jobb var at arbeidsgiver behandlet han på lik linje med alle andre og at han fikk ordinære arbeidsoppgaver. Samtidig var det rom for at han kunne komme og snakke med de som kjente til fortiden hans hvis det skulle være noe. Det var også rom for at han fikk ta den tiden han trengte på å komme inn i sin nye livssituasjon. Personen sier at han opplevede det som godt at noen forventet noe av han.

Det viktigste som trekkes frem for å lykkes for den enkelte i et prosjekt som TAFU er at man må ha motivasjon og vilje til å endre livet sitt og vilje til å komme i arbeid. Samtidig er det å få motivasjon og troen på at endring er oppnåelig noe av det viktigste TAFU-prosjektet kan bidra med.

TAFU-prosjektet omtales særlig positivt fordi prosjektet består av personer med ulik faglig bakgrunn, slik at de har ressurser til å hjelpe den enkelte med ulike utfordringer, både hva gjelder rusproblemer, det å få unna uoppgjorte ting fra fortiden (kriminaltet, økonomiske vansker m.m.) og så videre. Videre fremheves det at det er veldig positivt at man alltid føler seg velkommen i TAFU og at de aldri gir den enkelte opp, og det er alltid mulig å komme innom for å få snakke om ting som oppleves vanskelig, selv om man er ferdig med kursene.

Personen sier at hvis han ikke hadde fătt tilbud om deltakelse i TAFU, hadde han sikkert fortsatt hatt de samme utfordringene som før og vært i NAV. Personen ser svært positivt på fremtiden, han trives veldig godt $\mathrm{i}$ jobben sin og eier nå egen bolig og bil. 


\subsubsection{Målgruppe}

TAFU-prosjektet er rettet mot straffedømte mellom 18 og 40 år. De som $\emptyset n s k e r$ å delta i prosjektet og er motivert for det, får delta på kurs. Kursene forbereder den enkelte til deltakelse i arbeidslivet. Deretter får de hjelp fra TAFU-prosjektet til å få praksisplass i en ordinær bedrift. Målet er at dette på sikt skal føre frem til et ordinært, fast ansettelsesforhold.

Bedriftene varierer fra gang til gang, ut fra om bedriften har behov for å ta imot arbeidskraft, om bedriften ønsker å tilby praksisplass, om bedriften etter hvert har mulighet til å tilby et fast ansettelsesforhold, om bedriften virker å imøtekomme kursdeltakerens individuelle behov og så videre.

Det avholdes treukerskurs fire ganger i året, med ti til 15 deltakere. Det er meningen at TAFU-prosjektet skal ta opp rundt 40 deltakere i året.

\subsubsection{Virksomhetens rolle og gevinst}

Bedriftene i TAFU prosjektet har deltatt ved å tilby praksisplass og eventuelt fast ansettelse til deltakerne.

Prosjektleder i TAFU Rogaland mener at motivasjonen for en bedrift til å først tilby praksisplass og så eventuelt fast ansettelse til prosjektdeltakerne er ulik. Fra intervjuene vi har gjennomført nevnes blant annet følgende forhold:

- Dersom samarbeidet mellom arbeidsgiver og arbeidstaker fungerer, vil bedriften få en lojal medarbeider.

- Sosialt engasjement.

- Tilgang til arbeidskraft.

- Noen bedrifter har et uttalt mål om å ville bidra i samfunnet/ta samfunnsansvar.

- Det å ta samfunnsansvar på denne måten kan virke positivt for bedriftens omdømme.

Baker Hughes er en av bedriftene som har ansatt prosjektdeltakere fra TAFU Rogaland-prosjektet. I intervju med en representant fra bedriften får vi oppgitt at de totalt har tre kandidater fra prosjektet. To av disse har fătt ansettelse, hvorav en er lærling og en er på utplassering.

Bedriften stiller ikke andre krav til kandidatene fra TAFU-prosjektet enn ved ordinære ansettelser. De som ansettes må være praktisk anlagt ut fra arbeidet som gjøres i bedriften, og de ansatte må kunne engelsk, da alle instrukser gis og prosedyrer er på engelsk. Videre er det en selvfølge at alle følger bedriftens arbeidsreglement, de må komme og gå når de skal, samt være selvgående og ha vilje til å arbeide og få til noe. 


\subsubsection{Samarbeid mellom sentrale aktører}

TAFU-prosjektet er et samarbeid mellom flere aktører. Prosjektet er et nasjonalt prosjekt som per i dag tilbys i Rogaland og Tromsø. I intervju med prosjektleder av TAFU Rogaland oppgis det at prosjektet per i dag består av 6,6 årsverk.

Involverte parter er kriminalomsorgen, kommunene, fylkeskommunene, NAV og private tiltaksaktører. I prosjektkommunene sitter representanter fra disse aktørene sammen i kontorfellesskap. Fylkesmannen i Hordaland har det nasjonale overordnede ansvaret for prosjektet.

Det foreligger ikke faste samarbeid med bestemte bedrifter. Bedriftene som tilbyr kursdeltakerne arbeid, varierer fra gang til gang. Det er imidlertid i hovedsak private bedrifter det her er snakk om.

På spørsmål om hvem som er de mest sentrale bidragsyterne og aktørene i prosjektet, svarer en av respondentene at det er prosjektdeltakerne selv. Uten deres vilje til å gjennomføre programmet, ville prosjektet aldri kunne ha eksistert.

\subsubsection{Finansiering}

Prosjektet finansieres av de involverte partene gjennom prosjektmidler, øremerkede tilskudd eller tilsvarende.

\subsubsection{Forutsetning for suksess}

Fra intervjuet med prosjektlederen i TAFU Rogaland, fremheves særlig følgende suksessfaktorer for måloppnåelse av TAFU-prosjektet:

- Kreves grenseoverskridende samarbeid mellom flere etater. Den enkelte må stilles seg lojal til TAFUs målsetning, noe som innebærer at man må gå utover rammene den enkelte aktør normalt jobber innenfor.

- Det metodiske grunnlaget for prosjektet, som er konsekvenspedagogikk. Dette er prøvd ut i over 20 år for målgruppen som TAFU-prosjektet har. Metoden startet i Danmark, spredte seg til Sverige og nå Norge.

- Partene som er involverte må på ledelsesnivå ha et ønske om å lykkes. Prosjektet må ha medarbeidere som drar i samme retning.

- Kursdeltakernes ønske og vilje til å gjennomføre prosjektet. 


\subsubsection{Utbredelse av initiativet}

Prosjektet foregår både i Troms og Rogaland. Det ble satt i gang i 2009 og skulle i utgangspunktet vare til 2013. I evalueringen av TAFUprosjektet anbefales det at prosjektet videreføres og at det settes i gang flere steder i Norge (Neumann og Pettersen 2013). I sluttrapporten fra Fylkesmannen i Hordaland fremgår det at TAFU skal avvikles som prosjekt 31. desember 2013.7 Det vurderes nå om TAFU skal forlenges/over i ordinær drift med utvidelser.

\subsubsection{Kilder}

Siren Økland Vardøy, ansatt ved Fylkesmannen i Hordalands kontor.

Aksel Onarheim, prosjektleder TAFU Rogaland.

Kjell Sturla Johansen, Baker Hughes.

Prosjektdeltaker (anonym).

DAMVAD ble først gjort oppmerksom på TAFU-prosjektet ved å søke på internett. Dette var utgangspunktet vårt for å begynne en videre informasjonsinnhenting om prosjektet, slik at vi kunne vurdere relevans for dette prosjektet.

\subsection{Ung jobb Haugesund}

\subsubsection{Kort om initiativet}

I Haugesund samarbeider den lokale fotballklubben med NAV, Haugesund kommune og den lokale attføringsbedriften om å få unge som har havnet utenfor arbeid og skolesystemet ut i arbeidslivet.

Prosjektet bruker interesse for fotball og idrett, og det samholdet dette skaper, som en inngangsport til arbeidslivet. Prosjektet gir ungdom relevant yrkeserfaring og positive opplevelser knyttet til arbeid.

Tanken bak prosjektet er at fotball er en aktivitet som både samler unge, gir positive opplevelser og skaper samhold og felles identitet. Eksisterende kunnskap om fotballklubben Haugesund hos de unge gir insentiver hos noen til gå mer helhjertet inn i et slikt tilbud. Samtidig skaper fotball en arena for samhold og identitet hos de unge. Prosjektet gir

${ }^{7}$ Sluttrapport fra Fylkesmannen i Hordaland (2013). 
også fotballklubbens samarbeidspartnere mulighet til å gjøre et sosialt samfunnsarbeid.

Gjennom kursing og tett oppfølging hjelper prosjektet ungdom å ta kontroll over eget liv og bli forberedt til arbeidslivet. Ungdommene får både kurs, coaching og arbeidserfaring. Ideen kommer opprinnelig fra Trondheim hvor Rosenborg Ballklubb (RBK) deltar i et prosjekt for å få unge utenfor skole og arbeidsmarkedet tilbake til skole eller i jobb. RBKprosjektet er imdilertid innrettet noe annerledes enn Ung Jobb Haugesund, samt at Ung Jobb Haugesund har mindre økonomiske og mennesklige ressurser involvert i progsjektet.

Prosjektet startet høsten 2012. Grupper på 12 personer blitt tatt inn i 6 måneder hvor de skal prøve seg i arbeid og få tilvenning til arbeidslivet. Mot slutten av de 6 månedene skal ungdommene jobbe i ordinære bedrifter, helst hos en av samarbeidspartnerne eller sponsorene til Fotballklubben Haugesund.

Prosjektet skal veilede og hjelpe ungdommene til å bli forberedt på arbeidslivet. Dette innebærer blant annet kursing i muntlig fremstillingsform, selvrepresentasjon, hvordan skrive CV og jobbsøknad, samt drilling på punktlighet, ærlighet og ansvarsfølelse.

Prosjektet veileder også de unge om viktigheten av en sunn livsstil. Dette innebærer fokus på kosthold og mosjon, og opplæring i hvor viktig disse faktorene er for god mental helse. Dette baseres på en tanke om at $\varnothing \mathrm{kt}$ bevisstgjøring vil styrke muligheten til å påvirke sin egen situasjon og de valg man tar, og dermed økt kontroll over eget liv.

Prosjektet er delt i tre faser Første fase består av kurs og kompetanseheving. De unge lærer om fotballklubben, fysisk trening og kosthold. De får også individuell karriereveiledning, coaching og hjelp til å ta styring over eget liv. I denne fasen har prosjektet som mål å oppnå stabilt oppmøte, avklare interesser og egenskaper og gi de unge innsikt i arbeidslivets spilleregler. Fasen består av kurs og kompetanseheving og er et samarbeid mellom Fotballklubben Haugesund og Haugaland Industri. Fasen varer i omtrent 1 måned

Fase 2 består av opplæring i en utvalgt bedrift eller hos fotballklubben. Dette er i hovedsak arbeidstrening med fokus på bevisstgjøring av egne ressurser, interesser og muligheter. Fasen varer i omtrent 2-3 måneder, men er individuelt tilpasset. Noen trenger mer tid enn 2-3 måneder og opplegget tilpasses da etter dette.

Fase 3 består av arbeidstrening i bedrift eller hos Fotballklubben Haugesund og arbeidstrening i bedrift med mål om ordinær jobb. I denne fasen er det en avslutning og videre aktiviteter planlegges. Mål er å 
komme i ordinær aktivitet, det vil si tilbake i arbeid eller skole. Denne fasen varer i omtrent 1-2 måned.

\subsubsection{Resultat}

Prosjektet har hatt to runder så langt. I hver runde har grupper på 12 personer hatt jobbtilvending. $75 \%$ av de som har deltatt i prosjektet er i jobb eller har lærlingeplass i dag.

Daglig leder i FK Haugesund sier at de har sett en enorm utvikling hos de unge i løpet av den relativt korte tiden. De unge har gått fra å være negative og mangle tro på seg selv til å være positive, ha tro på seg selv og en mestringsfølelse. Ved å stille klare krav, gi tett oppfølging og forberede de på arbeidslivet har prosjektet gitt de unge en ny start.

Vi har intervjuet en av brukerne, som sier at prosjektet har hatt stor betydning for ham og hjulpet ham dit han ønsker å være.

\subsubsection{Målgruppe}

Tilbudet er tiltenkt ungdom i alderen 18-25 år, som faller utenfor ordinære ordninger som jobb og skolegang. I følge Attføringsbedriftene var ca. 100 ungdommer (18-25 år) i Haugesund på sosialstønad i 2012.

\subsubsection{Virksomhetens rolle og gevinst}

Fotballklubben Haugesund har en sentral rolle i prosjektet og har bidratt med lokaler, tilskudd og arbeidsinnsats. Gjennom prosjektet får fotballklubben anledning til å gjøre noe for lokalområdet og gi tilbake til samfunnet. Samtidig er prosjektet en fin profilering av klubben og sammenfaller med de verdiene som fotballklubben ønsker å fremme.

Fotballklubbens sponsorer får også anledning til å delta i prosjektet ved å tilby praksisplasser for deltakerne. På denne måten kan også de gi tilbake til samfunnet og profilere seg selv på en positiv måte.

\subsubsection{Samarbeid med aktører}

Ung Jobb i Haugesund er et samarbeidsprosjekt mellom Haugesund kommune, NAV Rogaland, Fotballklubben Haugesund (FKH) og AS Haugesund Industri.

Haugaland Industri, Haugesund kommune og NAV Haugesund tok kontakt med FK Haugesund som umiddelbart tente på ideen. "Jeg brukte omtrent 30 sekunder på å bestemme meg for at dette skulle vi gjøre, og 
det før jeg egentlig visste hva jeg sa ja til" sier Asle Skjærstad daglig leder i FK Haugesund.

\subsubsection{Finansiering}

Prosjektet er et samarbeidsprosjekt mellom FK Haugesund, AS Haugaland Industri, Haugesund kommune og NAV Haugesund.

FK Haugaland har bidratt med lokaler, tilskudd og arbeidsinnsats. AS Haugaland Industri har bidratt med to fulltidsstillinger og Haugesund kommune har også gått inn med en del midler. Forutsetninger for suksess Suksesskriterier som nevnes av de vi har intervjuet er:

- Tid til å følge opp de unge hele veien

- Engasjerte medarbeidere og ledere

- Langsiktig tenkning

- Lokal tilpasning.

\subsubsection{Forutsetninger for suksess}

Suksesskriterier som nevnes av de vi har intervjuet er:

- Tid til å følge opp de unge hele veien

- Engasjerte medarbeidere og ledere

- Langsiktig tenkning

- Lokal tilpasning.

\subsubsection{Utbredelse av initiativet}

Prosjektet er utviklet med inspirasjon fra Trondheim og Rosenborg Ballklubs engasjement $i$ et lignende prosjekt. Ung jobb Haugesund er imidlertid et prosjekt med mindre ressurser enn Rosenborgs prosjekt. Så langt har 29 personer deltatt på UngJobb Haugesund. 5 personer i et prøveprosjekt og to grupper på 12 personer. Høsten 2013 skal en ny gruppe på 12 starte opp. 


\subsubsection{Kilder}

Informanter:

Haugaland Industri, ved Ingrid Thuestad.

Fotballklubben Haugesund, ved daglig leder Asle Skjærstad.

NAV Haugesund, prosjektansvarlig.

Prosjektdeltaker (anonym).

www.fkh.no

DAMVAD ble først gjort oppmerksom på dette prosjektet ved å søke på internett. Dette var utgangspunktet vårt for å begynne en videre informasjonsinnhenting om prosjektet, slik at vi kunne vurdere relevans for dette prosjektet.

\subsection{Satsing på unge i Nord-Trøndelag}

\subsubsection{Kort om initiativet}

I Nord-Trøndelag har det over tid blitt etablert en særlig satsing på unge som ikke har fullført videregående opplæring og som står uten arbeid. Arbeidet baserer seg på et samarbeid på tvers mellom flere offentlige instanser og næringslivet i Nord-Trøndelag. Fosdalen Industrier har særlig vært sentrale.

Satsingen faller i dag ikke inn under et eksakt prosjekt, men det har tidligere vært iverksatt en satsing, kalt Ung gnist, som denne overordnede satsingen på unge i Nord-Trøndelag kan sies å være en videreføring av. Ung gnist er nå avsluttet.

Bakgrunnen for at det ble iverksatt en ekstra innsats rettet mot ungdom, var at NAV registrerte at det var mange unge som var i NAVsystemet og som stod uten jobb. Mange av disse hadde heller ikke fullført videregående opplæring.

I dette arbeidet ble Fosdalen Industrier viktige, da de hadde behov for arbeidskraft, samtidig som bedriften hadde et ønske om å bidra i arbeidet med å hjelpe unge som stod utenfor arbeidsmarkedet til å få jobb.

Gjennom intervjuene vi har gjennomført har bedriftens engasjement blitt eksemplifisert ved å vise til en spesiell hendelse, der rektoren ved en grunnskole tok kontakt med bedriften vedrørende en gutt som gikk i 10. trinn og som hadde utfordringer med å klare å gjennomføre skolegangen. Det ble enighet om at denne ungdommen skulle bli tatt inn på utplassering i Fosdalen Industrier. På det tidspunktet var målet at gutten skulle klare å 
gå opp som lærekandidater. Resultatet ble at den unge etter hvert oppnådde fullt fagbrev. I dag er personen fast ansatt $\mathrm{i}$ bedriften.

Motivasjonen bak arbeidet som nå gjøres inn mot de unge som står utenfor arbeidslivet, er å iverksette tidlig innsats slik at ungdommene ikke skal bli værende i NAV-systemet og at de skal få seg en utdanning og jobb.

\subsubsection{Resultater}

Fosdalen Industrier har totalt rundt 35 ansatte. Gjennom sitt engasjement for unge har de ansatte sek til sju personer. Stort sett alle har fătt utdanning (fagbrev) og er i jobb.

I intervjuet med bedriften ble det også vist til at bedriften og de øvrige ansatte har lært mye av arbeidet. De har blitt mer oppmerksomme på at det finnes mange som står i en utfordrende livssituasjon, men som likevel har mye å bidra med. De har erfart at det er viktig å ikke avskrive folk som i utgangspunktet har det vanskelig. Ved å gi disse en ny sjanse, slik at de får vist at de kan og at det føler at de betyr noe, gjør at de kan bli viktige bidragsytere i samfunnet, og de fremstår som gode eksempler for andre i lignende livssituasjoner.

NAV viser også til at noe av de mest positive resultatene fra innsatsen som gjøres, er at mange av de unge oppnår fagbrev og får fast jobb. Implikasjonene av dette er at de unge kommer seg ut av NAV, de bidrar til samfunnet og får rettet opp livene sine. Mange av de unge sliter med rusproblemer og kan ha en kriminell bakgrunn.

I intervju med en av de som i dag jobber ved Fosdalen Industrier, som resultat av satsingen på unge, trekker personen særlig frem at det å ha kommet i kontakt med bedriften gjennom NAV har gitt han en unik sjanse til å få seg formell utdanning. Fra før, hadde vedkommende ingen utdanning utover grunnskole og hadde startet å jobbe rett etter 10 . trinn. På grunn av at familien flyttet, ble personen vi intervjuet arbeidsledig og måtte registrere seg hos NAV. I dag er personen ansatt som lærling i Fosdalen Industrier og har mål om å fullføre fagbrev. Etter fullført fagbrev håper og tror personen vi snakket med at det er gode muligheter til å få fast jobb i bedriften. Et annet moment som ble nevnt i intervjuet som svært positivt, var at gjennom ansettelsen i Fosdalen Industrier, så har personen regelmessig fått tilbakemelding og oppfølging av ansvarlige i bedriften og Opplæringskontor for teknologifag (OTEK), både på det faglige og det mer personlige. 


\subsubsection{Målgruppe}

Innsatsen mot de unge som nå giøres i Nord-Trøndelag innebærer en særlig satsing mot unge som har utfordringer med å fullføre videregående opplæring og som ikke har jobb, og der alternativet er NAV.

I intervjuet med Fosdalen Industrier kom det frem at de særlig ønsker å jobbe inn mot de unge fra 16-års alderen opp til 20-årene. Det som ble trukket frem som en viktig faktor for å særlig satse på ungdom er at det offentlige virkemiddelapparatet for denne gruppen er relativt stort, noe som er viktig for å oppnå gode resultater.

Det settes ikke noen spesielle kriterier for de unge som NAV "fanger opp" som mulige kandidater for å inngå i det tverrfaglige arbeidet som gjøres. Det stilles heller ingen særlige krav fra Fosdalen Industrier. Det som er viktig er at de unge har vilje og motivasjon til å få opplæring/utdanning og at de ønsker å komme i jobb. Dette er et ønske hos de aller fleste unge som kommer til NAV.

\subsubsection{Virksomhetens rolle og gevinst}

Fosdalen Industriers hovedrolle har vært å ansette unge som de kommer i kontakt med, primært gjennom NAV, og gjennom ansettelsen gi de unge opplæring med mål om å ta fagprøve. Utover det faglige, har bl.a. ansvarlige i bedriften fulgt opp de unge og gitt opplæring på mer personlige forhold, som hva som forventes av en ansatt $\mathrm{i}$ arbeidslivet.

Bedriftens gevinst ved å bidra inn i satsingen, er på flere områder sammenfallende med den overordnede gevinsten og resultatene av satsingen på unge. Som omtalt tidligere får bedriften tilgang på arbeidskraft, de får lojale medarbeidere og det gjør noe med hele samholdet og arbeidskulturen i hele bedriften.

I intervju med Fosdalen Industrier ble tre forhold vektlagt som viktige for bedriftens motivasjon til å bidra til å hjelpe unge til å få jobb:

- Først og fremst har arbeidet mot de unge utspring i et ønske om å gi enkeltindivider en ny sjanse, da det oppleves som meningsfullt å kunne hjelpe.

- Bedriften ønsker å vise sosialt engasjement og ta samfunnsansvar, både lokalt og i samfunnet for øvrig.

- Bedriften trenger arbeidskraft. 


\subsubsection{Samarbeidende aktører}

Gjennom intervjuene vi har gjennomført er det flere sentrale aktører som nevnes som viktige for at innsatsen rettet mot de unge skal lykkes:

- NAV.

- Arbeidslivssenteret.

- Fylkeskommunen, herunder Opplæringskontoret (OT), fagrådgivere, PPT-tjenesten og videregående skole.

- Opplæringskontoret for teknologifag (OTEK).

- Næringslivet - og da spesielt Fosdalen Industrier. ${ }^{8}$

- I noen tilfeller helsevesenet.

\subsubsection{Finansiering}

Fosdalen Industrier har ikke egne midler til arbeidet som gjøres. Bedriftens ressurser benyttes på "frivillig basis."

Det er imidlertid slik at de offentlige aktørene som er del av samarbeidet kan på ulike måter bidra med ressurser for å støtte opp under bedriftens innsats, gjennom penger, kompetanse og så videre. For eksempel sier NAV at det i utgangspunktet ikke stilles krav til bedriften om at de skal gi den unge fast ansettelse, og det starter gjerne med at den unge får en prøveperiode i bedriften. I denne perioden skal ikke bedriften har lønnsutgifter og lignende tilknyttet den unge. Det vises også til at NAV-kontoret i Verran kommune har fătt egne midler til å særlig satse på unge.

\subsubsection{Forutsetninger for suksess}

Gjennom intervjuene vi har gjennomført er det flere forhold som har blitt nevnt som viktige faktorer for at arbeidet som gjøres for å hjelpe unge inn i arbeid skal lykkes:

- Engasjerte ildsjeler i alle ledd.

- Alle involverte parter må ha et eierskap til arbeidet.

${ }^{8}$ I intervjuet med fylkeskommunen ble særlig Fosdalen Industrier trukket frem som en svært engasjert bedrift. Det ble samtidig påpekt at det var flere bedrifter som kunne være interesserte, men jo flere bedrifter som vil bidra, jo mer ressurser må det også avsettes i de øvrige offentlige instansene. Born Design ble nevnt som en annen bedrift som har vist engasjement og vilje til å bidra. 
- Relevante offentlige instanser må være positivt innstilt til å tenke utradisjonelt og til å jobbe på tvers av tradisjonelle institusjonsgrenser.

- Bedriftene kan ikke få alt ansvaret alene. Alle instanser må snakke sammen og bidra; gjerne utenfor det som normalt ligger innenfor det tradisjonelle ansvarsområdet for den enkelte instans.

- Bedriftene som deltar i et slikt arbeid må "fritas" for alle formaliteter som kreves i det offentlige systemet. De offentlige aktørene må bidra med å legge til rette for at relevante instanser trekkes inn, finne frem muligheter til finansiering, prosesskunnskap og så videre.

- Det må avsettes nok ressurser, både i det offentlige slik at de kan gjøre en målrettet innsats og følge opp bedriftene som ønsker å bidra, men også slik at bedriftene som bidrar får noe igjen økonomisk for deres innsats.

- Det er viktig at det bygges opp gjensidig tillit mellom alle aktørene, herunder mellom bedriften, det offentlige og den enkelte som står uten arbeid.

- Den enkelte unges situasjon må kartlegges nøye og all relevant historikk og alle utfordringer må fremkomme, slik at bedriften på en best mulig måte kan tilrettelegge arbeidsforholdene i forhold til dette, og slik at de øvrige instansen skal kunne iverksette riktige tiltak. Den unge må selv være med på dette (dialogen skal ikke gå bak ryggen på den det gjelder).

- NAV, som ofte er den første som møter de unge det her er snakk om, må ha nok kunnskap om unge og deres utfordringer. De unge må møtes på "hjemmebane". NAV må ha nok tid til å snakke med den det gjelder, de unge må tas på alvor, hver enkelt ungdom må få en fast kontaktperson slik at det kan bygges opp tillit mellom den unge og systemet. Det er viktig at denne faste kontaktpersonen både kan stille riktige krav og samtidig motivere den enkelte ungdom. Det er også viktig at saksbehandleren i NAV kjenner til systemet og nettverket, slik at de riktige aktørene blir involvert i arbeidet.

- Bedriften trekker frem at det er viktig at hele bedriften er med på innsatsen som gjøres og at alle ansatte i bedriften er informert og involvert. På denne måten skapes det et eierskap blant alle ansatte til arbeidet som bedriften gjør for de unge. Alle ansatte i Fosdalen Industrier blir informer om arbeidet som gjøres, det er opprettet en fadderordning. Fagbevegelsen, tillitsvalgte og verneombudet er sentrale å inkludere.

- Det er viktig at den enkelte unge får en ny sjanse gjennom å tilbys et arbeid og at personen får oppgaver som skaper mestringsfølelse, da 
mange av disse både har et anstrengt forhold til skolegang og dårlig selvtillit til egenverdi og hva de kan bidra med.

\subsubsection{Utbredelse av initiativet}

Den generelle satsingen på unge som her er omtalt, kan sies å være en videreføring av et nå avsluttet prosjekt kalt Ung gnist. Det er per i dag ingen planer om å konkret starte opp igjen selve Ung gnist-prosjektet, men satsingen på unge og samarbeidet mellom Fosdalen Industrier og de andre involverte aktørene ser per i dag ut til å fortsette fremover.

\subsubsection{Kilder}

Fosdalen Industrier, ved Ola Kristian Folladal.

Nord-Trøndelag Fyleskommune, ved Tanja Tangstad. Tidligere ansatt i NAV med prosjektansvar for Ung gnist.

Prosjektdeltaker (anonym).

DAMVAD ble først oppmerksom på Ung gnist-prosjektet gjennom www.idebanken.no. Etter hvert som vi begynte å se nærmere på prosjektet og innhente informasjon, ble vi kjent med at Ung gnist er avsluttet, men at det per i dag er en generell satsing på unge som faller utenfor arbeidslivet, uten at dette er organisert som et fast prosjekt.

\subsection{Sandefjordmodellen}

\subsubsection{Kort om initiativet}

Sandefjordmodellens mål er å hjelpe unge sosialsøkere til å søke og få jobb. Alternativet er at de unge forblir sosialsøkere. Det er flere underprosjekter til Sandefjordsprosjektet, for eksempel Tiltak på timen og Arbeid først.

Bakgrunnen for prosjektet var at Fylkesmannen i Vestfold kontaktet NAV og et utvalg av bedrifter, herunder Jotun, som er en stor aktør i Sandefjord. Dette fordi det var et ønske om å endre situasjonen med at det var mange unge under 30 år som stod utenfor arbeidslivet. Statistikken viste at Vestfold fylke kom dårligere ut i så henseende enn andre fylker i landet, og Sandefjord kom dårligere ut enn de andre byene i Vestfold.

Sandefjordsmodellen startet med en konferanse. Utgangspunktet var at NAV kom til Jotun for å spørre bedriften hva de trodde var den største utfordringen. Det som kom tydelig frem var at NAV manglet arbeidslivskunnskap og trengte kunnskap om bedriftenes eksakte behov for kom- 
petanse og hva som faktisk skjer av arbeid i bedriftene. Det ble slik dannet et rom for dialog mellom flere store bedrifter i Sandefjords-regionen og NAV, der problemstillinger kunne fremsettes fra begges hold og hvor de ulike aktørene kunne utfordre hverandre på hva den enkelte kunne bidra med. Også bemanningsbedrifter, som Adecco og Manpower, ble involvert i arbeidet.

\subsubsection{Resultater}

Gitt at Sandefjordmodellen består av underprosjekter, har noen av prosjektene vært mer vellykket enn andre. For eksempel har det blitt gjennomført en jobb-audition for prosjektets målgruppe, der for eksempel ulike hoteller fra større hotellkjeder deltok for å få tak i arbeidskraft. Seansen førte frem til at flere av prosjektdeltakerne fikk (midlertidig) jobb.

Manpower har formidlet deltakere videre til bedriftene. De anslår at omtrent 10-15 av deltakerne er formidlet videre til bedriftene.

Fra intervjuet med Jotun, har de ikke eksakt kjennskap til hvor mange de har gitt jobb gjennom prosjektet. Dette skyldes at de i hovedsak får formidlet arbeidskraft gjennom Manpower, herunder unge som er tilknyttet NAV på grunn av at de står uten arbeid. På denne måten skiller ikke bedriften mellom "NAV-ungdommene" og andre unge som formidles gjennom Manpower. Jotun viser at alle ansatte uten fagbrev får dette finansiert av bedriften og alle som dette gjelder, har bestått. For bedriftens del er et viktig resultat av prosjektet at de har lært veldig mye av prosessen fra prosjektstart frem til i dag. Det har vist seg at man kommer langt med dialog mellom næringslivet, offentlige relevante instanser og andre sentrale aktører. Næringslivet har også sett at det hjelper å stilles krav som forutsetning for at de skal kunne bidra med sin del inn i et prosjekt som Sandefjordmodellen. Blant annet ble det stilt krav om at bedriftene måtte ha en fast kontaktperson i NAV og at NAV måtte ta ansvar for utfylling av skjemaer og andre formaliteter. Bedriftenes bidrag er å ta inn de unge, snakke med dem og få dem i arbeid.

Prosjektet har også resultert i at bedriftene har utarbeidet informasjon til unge om hva som kreves av dem i arbeidslivet, som for eksempel hvilke kompetansekrav som settes, hvilke holdninger og atferd som forventes av ansatte, at de må komme og gå når de skal, hvordan arbeidsgivere oppfatter en persons CV dersom vedkommende (frivillig) har gått $\mathrm{i}$ lengre perioder uten jobb, hva det medfører dersom man har høyt sykefravær og så videre. Jotun har ingen spesielle krav til sine ansatte som de tar inn fra prosjektet. Disse behandles likestilt med andre ansatte. Et 
generelt krav er fagbrev. De som ikke har dette når de ansettes, får det gjennom sitt ansettelsesforhold og bedriften finansierer dette. Det forutsetter imidlertid at de som ansettes uten fagbrev vil måtet ønske å oppnå dette.

Den åpne og ærlige dialogen mellom næringslivet og NAV har også resultert i at NAV har fått et skarpere fokus på arbeidslivets behov og vilkår. De har også blitt utfordret på å se nærmere på hvorfor akkurat unge i Sandefjordsområdet har svakere arbeidslivstilknytning enn unge ellers i landet. Her kan det nevnes at NAV og Sandefjord kommune har søkt om forskningsmidler og fătt dette gjennom Oslofjord-fondet. Midlene benyttes til at et eksternt forskningsmiljø ser nærmere på hvorfor akkurat Sandefjord har flere unge arbeidsledige enn andre byer i regionen. Neste steg er å se på hvorfor akkurat Vestfold fylke har høyere arbeidsledighet blant unge enn andre fylker.

Vi har intervjuet en av de som har fătt jobb gjennom den nye måten å tenke på som del av Sandefjordmodellen. Gjennom NAV deltok vedkommende i et kurs der deltakerne blant annet lærte å skrive gode CVer og å presentere seg selv. Gjennom kurset fikk de også konstruktiv tilbakemeldinger på dette. Kurset var spesielt rettet inn mot at kursdeltakerne skulle være med i et opplegg der bedrifter i hotell- og restaurantbransjen skulle presentere seg selv og hvilket kompetansebehov de hadde, og der prosjektdeltakerne skulle få presentere seg selv i en "odition" for bedriftene. Personen vi intervjuet ble ringt opp og tilbudt sommerjobb av ett av hotellene som var med i prosjektet i etterkant av denne seansen.

Etter noen dager i praksis ved hotellet fikk imidlertid kursdeltakeren vi snakket med tilbud om et vikariat hos en annen arbeidsgiver, og gjennomførte derfor ikke praksisperioden og sommerjobben. Når vikariatet utløp fikk personen imidlertid tilbud om fast jobb ved hotellet som i første omgang hadde tilbudt sommerjobb. Personen vi intervjuet starter derfor i fast jobb ved hotellet nå høsten 2013.

Noe av det som opplevdes som mest positivt ved å få delta i prosjektet var at kursdeltakerne fikk god anledning til å forberede seg på hvordan de skulle presentere seg selv for en potensiell arbeidsgiver, både skriftlig og muntlig. Det ble også trukket frem som positivt at kursdeltakerne fikk møte bedriften og slik få større forståelse av hva de var ute etter.

Personen vi intervjuet var fra før utdannet som kokk og hadde arbeidserfaring som kokk fra før. 


\subsubsection{Målgruppe}

Målgruppen i prosjektet er sosialsøkere i alderen 18 til 30 år.

\subsubsection{Virksomhetens rolle og gevinst}

Jotuns rolle i dette prosjektet har først og fremst vært å tilby de unge arbeidsplasser, fulgt dem opp både faglig og rundt det som går på personligutvikling og hjulpet de unge til å få seg en utdanning. I tillegg har bedriften vært aktive over for de øvrige partene i samarbeidet, blant annet i informasjonsoverføring rundt hvilken kompetanse og lignende bedriften trenger.

Etter NAVs vurdering er de viktigste motivasjonsfaktorene for bedriftene å delta i prosjektet å få tilgang til arbeidskraft og det å utvise sosial engasjement.

I intervjuet med Jotun, fremmes også sosialt engasjement som en viktig motivasjonsfaktor. Bedriften ser det som et samfunnsansvar å ta tak $\mathrm{i}$ utfordringen med at mange unge står uten arbeid, som både er et problem for den det gjelder, for næringslivet og samfunnet for øvrig. Jotun, med 900 ansatte i Norge, så at de som en stor bedrift hadde mulighet til å gjøre en forskjell.

\subsubsection{Samarbeid med aktører}

Både kommune, NAV og næringsliv er involvert i prosjektet. Noen av bedriften er med fra aktivitet til aktivitet, mens det blant annet er inngått samarbeidsavtale med Jotun, Fatland og Komplett.

I intervjuet med NAV fremholdes det at alle aktørenes bidrag er like viktig for at prosjektet skal kunne gjennomføres. Det opplyses også om at bedriftenes størrelse varierer, men at de til nå primært har vært i kontakt med de større bedriftene og konsernene.

\subsubsection{Finansiering}

Det er ikke satt av ekstra midler til prosjektet utover NAVs ordinære budsjett og de ressursene bedriftene stiller med. I intervjuet med Jotun ble bedriftens bidrag eksemplifisert med at, i tillegg til å ta inn unge og sørge for at de uten fagbrev får det, har bedriften bidratt med sitt nettverk og de har hatt NAV-ansatte på bedriftsbesøk for å heve kompetansen rundt hva som faktisk skjer av arbeid i bedriften og hvilket kompetansebehov bedriften har 


\subsubsection{Forutsettinger for suksess}

I intervjuene vi har gjennomført ba vi respondentene om å si noe om hva som anses for å være de viktigste suksesskriteriene for at prosjektet skal kunne gjennomføres og nå målet. Følgende faktorer trekkes særlig frem:

- Det er viktig at prosjektet er politisk og administrativt forankret på ledernivå hos de involverte aktørene.

- Næringslivet må ville bidra og være positivt innstilt.

- Dedikerte og motiverte prosjektmedarbeidere og riktige arbeidsverktøy.

- Samarbeid mellom alle sentrale aktører.

- Åpenhet, ærlighet og oppriktighet fra første dag mellom bedrift og ansatt, slik at bedriften kan legge til rette for de utfordringer den enkelte måtte ha (dette gjelder ikke kun for ansatte gjennom Sandefjordsmodellen, men alle ansatte).

- God opplæring i bedriften og godt arbeidsmiljø, slik at de ansatte har lyst til å komme på jobb hver dag.

\subsubsection{Utbredelse av initiativet}

I intervju med NAV, ble det ikke sagt noe om tidsrammen for prosjektet. Det ble imidlertid sagt at man fremover, i tillegg til å orientere seg inn mot større bedrifter, fremover vil legge mer vekt på å etablere samarbeid med lokalt næringsliv (mindre bedrifter).

\subsubsection{Kilder}

Svein Greger, leder ved NAV Sandefjord.

Anne Gro Mayca, ass. personalsjef Skandinavia/Norge, Jotun.

Prosjektdeltaker (anonym).

Manpower (Tommy Dahl Evensen).

DAMVAD ble kjent med dette prosjektet ved å snakke innledningsvis med en ansatt i NAV Sandefjord. Samtalen baserte seg på at vi ut fra et søk på internett så at det ble gjort ulike aktiviteter inn mot de unge i regionen. 


\section{De svenske cases}

\subsection{ABB ungdomssatsningar/IF Metalls Yrkesintroduktionsår}

\subsubsection{Kort om initiativet}

$\mathrm{ABB}$ är en global världsledande koncern inom kraft- och automationsteknik med rötter i Sverige och Schweitz. ABB har över 145000 anställda och driver verksamhet i mer än 100 länder. I Sverige har man verksamhet på flera orter i landet.

Nationellt är ABB är engagerade i ett antal insatser runt om i landet för att involvera ungdomar som står utanför arbetsmarknaden samt för att öka teknikintresset bland barn och unga. Genom att tidigt involvera barn och unga i företaget och öka intresset för teknik skapas förbättrade rekryteringsmöjligheter samtidigt som de unga ökar sina chanser till arbete inom teknikområdet. Företaget arbetar med barn och unga från tidig ålder, genom skolans samtliga faser för att sedan sedan erbjuda utexaminerade gymnasieelever prak-tik och anställning.

För att öka intresset för teknikämnet bland barn och unga arbetar $\mathrm{ABB}$, tillsammans med andra aktörer, bland annat med så kallade tekniklådor med experiment för barn i mellanstadieåldern. Dessutom är ABB med och bidrar till Teknikboken, en läroplansanpassad bok i teknik för högstadiet, samt Teknikåttan som arrangerar frågetävlingar för elever i årskurs åtta. Vidare finns tre stycken ABB Industrigymnasium i landet med sammanlagt drygt 350 elever.

\subsubsection{Resultat}

Framgångarna har varit större än man förväntade sig vid projektstart, Idag har 35 av 36 deltagare antingen ett arbete inom ABB eller har gått vidare till annan anställning. 


\subsubsection{Målgruppen}

För insatsen i Karlskrona på High Voltage Cables är målgruppen arbetslösa personer under 24 år med avslutad teknisk gymnasieutbildning. Insatsen har riktats mot både tjejer och killar som tillhör målgruppen, men det har enbart varit killar som sökt sig till och genomfört projektet. Målgruppen har valts för att matcha kraven för Yrkesintroduktionsåret samtidigt som ABB ser detta som en passande målgrupp för de tjänster som erbjuds och det behov som finns.

\subsubsection{Företagets roll och nytta}

ABB är sedan länge engagerade i många olika typer av insatser riktade mot unga. Det främsta syftet med dessa insatser är att tidigt få barn och unga intresserade av teknik för att stimulera till teknikinriktade utbildnings- och yrkesval senare i livet. För ABB handlar det förstås i hög grad om att säkra företagets framtida behov av kompetent arbetskraft, såväl lokalt som nationellt.

I detta projekt sammanföll ABB:s intressen med LO-förbundet IF Metalls och Arbetsförmedlingens kampanj Yrkesintroduktionsåret. ${ }^{9}$ ABB High Voltage Cables i Karlskrona har genomfört en satsning för att ge 36 arbetslösa ungdomar med gymnasieutbildning betald praktik och chans till framtida jobb. ${ }^{10}$

Företagets motiv för att delta har varit att säkra framtida rekryteringsbehov och samtidigt ta ett samhällsansvar genom att bidra till att motverka ungdomsarbetslösheten. Samtidigt som de unga har fătt arbete har företaget fått förnyad rekryteringsbas att satsa på långsiktigt samt ny positiv energi i verksamheten.

\subsubsection{Samarbete med andra aktörer}

ABB, IF Metall och Arbetsförmedlingen (den statliga myndigheten för arbetsförmedling) är involverade i satsningen inom Yrkesintroduktionsåret i Karlskrona. I de många satsningar som görs för att öka teknikintresset bland barn återfinns bland annat Mattecentrum, Kungliga Ve-

\footnotetext{
${ }_{9}^{9}$ Avtal för yrkesintroduktion är ett initiativ av fackförbundet IF Metall (som organiserar 350000 svensika industriarbetare) med syfte att öka tillgången på arbetskraft med tillräcklig kompetens inom teknikbranschen. Yrkesintroduktionen innebär visstidsanställning med garanterad handledd yrkesutbildning. ${ }^{10}$ ABB High Voltage Cables i Karlskrona är en affärsenhet inom ABB-koncernen där högspänningskablar för land och alla sorters sjökablar tillverkas.
} 
tenskapsakademien, Kungliga Ingenjörsakademien, Västerås stad och ABB Corporate research.

\subsubsection{Finansiering}

Initiativet har i huvudsak finansierats av ABB, men IF Metall har bidragit med en koordinator för projektet. Förutom koordinatorn består de finansiella insatserna främst av löner till de unga under praktiken, till en början $75 \%$ av en ordinarie ingångslön.

\subsubsection{Framgångsfaktorer}

Den främsta anledningen till att projektet har lyckats så väl är matchningen mellan målgruppen och dess behov och företagets behov.

För det första har rekryteringsprocessen varit noggrann. En grovsållning gjordes tidigt för att sedan enbart anta de personer man verkligen tror passar för arbetet. Det var även flera personer med olika bakgrund och infallvinklar med vid rekryteringen, vilket ses som en bidragande faktor till att lämpade ungdomar valts ut.

För det andra har målgruppen passat syftet och att de ungdomar som involverats matchar det behov som finns hos företaget och det arbete som ska genomföras. Jobbet innebär bland annat mycket skiftarbete, något som ofta passar unga personer bättre.

Ytterligare en framgångsfaktor som identifierats är att projektet har bedrivits av enagerade personer som varit drivande för att få projektet att löpa på och bli lyckat. Till dessa kan handledare och projektledare med flera räknas.

\subsubsection{Utvidgning och spridning av projekten}

ABB planerar att fortsätta med projektet på High Voltage Cable och man rekryterar fortlöpande på detta sätt. Företaget ser inga hinder för andra att göra detsamma och engagerar sig i liknande satsningar. I nästa steg kommer ABB att ändra målgruppen en aning för att fylla andra och nya behov som finns inom företaget. I det steget kommer aningen mer erfarna och äldre personer att efterfrågas. Företaget tror även att liknande satsningar kan genomföras på samma sätt på andra orter nationellt och inom de nordiska länderna. 


\subsubsection{Källor}

Suzanne Lagerholm, ABB, Informationsdirektör.

Annika Svensson, ABB High Voltage Cable, Karlskrona.

Ulrika Ekengren-Allen, ABB, Rekryteringschef.

\subsection{ICA}

\subsubsection{Kort om initiativet}

ICA och dess moderbolag ICA-gruppen är ett av Nordens största företag inom dagligvaruhandeln. Ägarstrukturen är komplex då de flesta av butikerna, men inte alla, ägs av enskilda handlare medan inköp, distribution etc. sköts gemensamt i koncernen. De individuella ICA-handlarna sysselsätter ca 70000 personer i Sverige, av dessa är omkring 20000 under 25 år. Unga utgör med andra ord en viktig målgrupp vad gäller rekrytering för de individuella butikerna. Från och med maj 2013 har ICA:s koncernledning satt som mål att butikerna sammantaget ska erbjuda 2000 praktikplatser för unga som står långt från arbetsmarknaden under det kommande året.

Utöver den ordinarie rekryteringen erbjuder många ICA-handlare redan idag praktiktplatser och lärlingsprogram, ofta knutna till något man kallar ICA Skolan. ICA Skolan är ett samlingsnamn för flera olika utbildningsinsatser inom ICA. Dessa utbildningar erbjuds ofta som ett komplement till personer som får genomgå praktik eller liknande i butikerna.

Eftersom insatserna bedrivs individuellt av varje handlare, ofta tillsammans med kommuner och Arbetsförmedlingen, varierar resultaten och antalet personer som erbjuds praktik stort. Från ICA-handlarnas förbund, samordningsorganisationen för de enskilda handlarna, rapporterar man att det på var och en av de enskilda ICA Maxi-butikerna (de allra största ICA-butikerna) handlar om 30-60 unga arbetslösa som får praktik på ett år, varav i genomsnitt hälften erbjuds tillfällig eller tillsvidareanställning. För de individuella handlarna betraktas praktikplatserna dels som en rekryteringsväg - ett sätt att nå ut till motiverade och engagerade ungdomar, men också som ett sätt att visa på ett samhällsengagemang lokalt.

Två exempel på ICA-handlare som satsat på unga är ICA-Maxi i Södertälje och ICA Supermarket (en något mindre butik) i Hjällbo i Göteborg. Förutsättningarna skiljer sig förstås åt för de båda, men arbetet med och incitamenten bakom ungdomssatsningarna är till stor del de samma. 


\subsubsection{Resultat}

I de två butikerna som får exemplifiera detta case - ICA Maxi i Södertälje och Ica Supermarket i Hjällbo i Göteborg - har Ica Maxi-butiken tar emot 40-45 praktikanter per år i perioder från några veckor upp till sex månader. Under denna period erbjuds ofta olika detaljhandelsrelaterade utbildningar genom ICA-skolan vilka betalas av kommunen eller Arbetsförmedlingen. I övrigt får praktikanterna arbetsuppgifter som motsvarar en anställds plus att de erbjuds individuell handledning. Upplägget i Hjällbobutiken är snarlikt, där omkring 15 unga per halvår praktiserar i tre månader.

Praktiken ökar de ungas möjligheter att få jobb, dels i de aktuella butikerna, men även generellt i samhället.

\subsubsection{Målgruppen}

Båda handlarna erbjuder praktikplatser till ungdomar mellan 16-25 år, men handlaren i Södertälje arbetar även med andra målgrupper, som till exempel utrikesfödda kvinnor i alla åldrar. Överlag är målgruppen unga som står relativt långt från en etablering på arbetsmarknaden.

\subsubsection{Företagets roll och nytta}

Insatserna sker i huvudsak på ICA:s initiativ, dels centralt i koncernen, dels lokalt genom att de enskilda handlarna är de som i praktiken driver insatserna. Företagens erbjudande består i huvudsak av praktikplatser, som i första hand vänder sig till unga som står lite längre ifrån arbetsmarknaden. Arbetsförmedlingen är förvisso med och finansierar en del av ersättningen till vissa av ungdomarna inom Arbetsförmedlingens ordinarie program.

För ICA är det viktigt att se denna insats som en del i ett större socialt ansvarstagande, som även omfattar andra grupper som står långt från arbetsmarknaden. ICA är ett i hög grad lokalt företag, dvs. företagets kunder finns där butikerna ligger. Inte minst i s.k. utsatta stadsdelar och förorter är det av största vikt för ICA att nå ett gott förtroende hos sina kunder. Att kunna erbjuda lokala ungdomar som annars skulle ha svårt att komma in på arbetsmarknaden en chans genom en praktikplats är därför ett viktigt led i ett sådant förtroendeskapande. Vidare är ICA förstås även beroende av ungdomar som arbetskraft. 


\subsubsection{Samverkan med andra aktörer}

Flera handlare i framför allt storstadsregionerna samarbetar med i synnerhet kommuner, skolan och Arbetsförmedlingen för att förmedla praktikplatser till unga arbetslösa. Detta gäller även handlarna i Södertälje och Göteborg. Såväl Södertälje som Hjällbo är områden i Stockholms- respektive Göteborgsregionen med relativt höga andelar födda utanför Norden och även relativt hög arbetslöshet.

ICA Maxi-handlaren i Södertälje samarbetar framförallt med högstadieskolor och gymnasier i regionen, samt med Södertälje kommun, för att få in praktikanter. Kommunen eller Arbetsförmedlingen (beroende på vilken insats det handlar om) betalar de utbildningsinsatser som vissa av praktikanterna erbjuds inom ICA-skolan. ICA-handlaren i Hjällbo ingår i ett partnerskap där sex handlare i nordöstra Göteborg finns med för att tillsammans med kommunen, Arbetsförmedlingen och föreningslivet erbjuda praktikplatser till arbetslösa ungdomar.

\subsubsection{Finansiering}

Insatserna finansieras i huvudsak av ICA själva, om man ser till själva erbjudandet av praktiktplatser. När det gäller de ungdomar som går vidare till utbildning via den s.k. ICA skolan står i första hand Arbetsförmedlingen för en del av ungdomarnas ersättning. Denna finansiering sker då inom ramen för Arbetsförmedlingens ordinarie program, varför inte riktigt alla omfattas av en sådan finansiering.

\subsubsection{Framgångsfaktorer}

En viktig framgångsfaktor bedöms av handlarna själva vara att man agerar utifrån ett tydligt affärsnyttaperspektiv. Man erbjuder inte praktikplatserna enbart för att visa på ett socialt engagemang, utan i och med detta engagemang och skapande av "good-will" både hos ungdomarna och i området som helhet, skapas bättre förutsättningar för att kunna bedriva en verksamhet som går med vinst. Både handlaren i Hjällbo och handlaren i Södertälje menar att andra handlare som försökt driva verksamhet i liknande utsatta områden där en stor andel är utrikes födda, inte förstått att man först måste etablera ett förtroende hos lokalbefolkningen innan man kan börja tjäna pengar.

Båda handlarna menar också att det har varit viktigt att inte ta emot för många praktikanter på en gång, för att på så sätt säkra en bättre etablering på arbetsplatsen för dem som kommer in. Maxihandlaren berättade om ett mindre lyckat exempel då 10 irakiskfödda kvinnor togs in 
inom ramen för ett projekt i samverkan med kommunen. Även om dessa kvinnor mottogs väl och sade sig få mycket nytta av sin praktik, så blev de inte lika väl integrerade i verksamheten som ett mindre antal antagligen hade blivit.

En annan viktig framgångsfaktor har varit att identifiera motiverade och arbetsvilliga individer. I det arbetet har ofta samarbetspartners i form av kommunen, Arbetsförmedlingen, skolor och lokala föreningar varit betydelsefulla.

\subsubsection{Utvidgning och spridning av projektet}

Butikscheferna avser att fortsätta arbetet med målgruppen unga. De framhåller att fler handlare borde se affärsnyttan i att arbeta med socialt engagemang och ansvarstagande. ICA centralt signalerar att de önskar se fler följa Södertälje- och Hjällbobutikernas exempel och erbjuda fler praktikplatser och arbeta med relationsbyggande i lokalsamhället. Bland annat har Tommy Söderberg, tidigare svensk landslagstränare i fotboll, anställts av ICA för att lyfta fram de goda exempel som finns på detta arbete inom koncernen, och hjälpa till att sprida kunskapen från dessa exempel vidare. Tanken är att det utifrån dessa exempel ska arbetas fram ett sammanhållet koncept för handledning, praktik och utbildning - anpassat till ungdomar - som alla ICA-handlare ska kunna implementera i sin verksamhet.

Förhoppningen är att utöver de 6000 praktikplatser som varje år erbjuds ungdomar i ICA-butiker, erbjuda ytterligare 2000 platser för ungdomar som har det särskilt svårt att etablera sig i arbete.

\subsubsection{Källor}

Lena Litens, ICA-handlarnas förbund.

Tommy Söderberg, ICA-handlarnas förbund.

Jonas Berg, VD ICA Maxi Södertälje.

Klas Peterson, VD ICA Supermarket Hjällbo.

Aydin Özkaya, arbetsmarknadskoordinator Södertälje kommun (även intervjuad om Telge tillväxt).

Möte med 10 deltagare i projektet K2 (genomgått samma insatser som ungdomar som gör praktik i Södertälje). 


\subsection{Telge Tillväxt}

\subsubsection{Kort om initiativet}

Telge tillväxt är ett delägt dotterbolag till det kommunala bolaget Telge AB i Södertälje, som också är huvudägare. Tillsammans med sex privata näringslivsaktörer (tillika delägare) drivs Telge tillväxt idag i projektform med stöd från Europeiska Socialfonden (ESF). Målet med projektet är att halvera ungdomsarbetslösheten i kommunen under projektperioden som varar från 2011 till årsskiftet 2013/2014.

Ett annat mål är att utveckla en långsiktigt hållbar modell för effektivare matchning av långtidsarbetslösa ungdomars kompetens och individuella målsättningar med arbetsgivarnas efterfrågan på arbetskraft.

Tillsammans med Arbetsförmedlingen identifieras deltagare till projektet som till en början får genomgå fyra veckors så kallad gröntjänst/yttre skötsel genom kommunen. Under dessa fyra veckor spenderar varje deltagare fyra dagar i gröntjänst och en dag med någon av Arbetsförmedlingens tre jobbcoacher som är involverade i projektet, och som Arbetsförmedlingen finansierar. Ungdomarna arbetar i grupper om 6-12 deltagare med en arbetsledare som löpande bedömer personernas arbete och motivation.

De första fyra veckorna fungerar som en slags prövotid för deltagarna. De som bedöms vara tillräckligt motiverade och engagerade får därefter en tidsbegränsad anställning inom Telge tillväxt på tre månader. Under dessa tre månader får ungdomarna avtalsenlig lön och matchas till arbetsgivare som vill hyra in arbetskraft. Matchningsprocessen påbörjas egentligen redan under de första fyra veckorna genom Arbetsförmedlingens jobbcoacher, och inget hindrar att man avslutar de fyra veckornas prövotid i förtid om man får arbete under den perioden.

Under hela perioden på Telge tillväxt får ungdomarna personlig coachning och stöd för att så snabbt som möjligt kunna bli uthyrd till ett arbete och en arbetsgivare som man är intresserad av. Detta ställer stora krav på arbetsledare och matchare i projektet som är måna om att visa alla lika stor uppmärksamhet och engagemang. I juni 2013 hade ca 350 ungdomar passerat projektet. Totalt finns tio personer involverade i projektarbetet: fem arbetsledare, två matchningschefer, en säljare, en strategichef och en VD. Därutöver har Arbetsförmedlingen, som nämnts, tre jobbcoacher involverade, som dock inte finansieras av projektet. 


\subsubsection{Resultat}

Telge tillväxt anser sig ha uppnått goda resultat. Hela $55 \%$ av de deltagande ungdomarna i projektet går vidare till arbete inom 3 månader. Ytterligare $18 \%$ går vidare till heltidsstudier. Dessutom blir $80 \%$ av dem som blir uthyrda till en arbetsgivare också anställda där senare.

\subsubsection{Målgruppen}

Projektets målgrupp är långtidsarbetslösa ungdomar i åldrarna 18-24 år. "Långtidsarbetslös" definieras som den som varit utan arbete i minst tre månader och då varit inskriven på Arbetsförmedlingen. Detta innebär också att ungdomarna i projektet är med i Arbetsförmedlingens jobb-garanti för ungdomar, en benämning på en status som ger tillgång till en viss typ av statliga insatser anpassade för målgruppen unga långtidsarbetslösa.

\subsubsection{Företagens roll och nytta}

Näringslivet i Södertälje är direkt involverade i projektet på två olika sätt och nivåer. Sex större företag är med i rollen av initiativtagare och delägare i företaget Telge Tillväxt $\mathrm{AB}$, där även Södertälje kommun är delägare. Men näringslivets engagemang stannar inte där. Ytterligare ett 80-tal lokala företag, mindre och medelstora, är också engagerade i projektet, genom att man hyr in arbetskraft från Telge tillväxt.

I Södertälje som länge varit en av de kommuner som relativt sett mottagit flest nya svenskar, och under en period också en kommun med hög arbetslöshet och många våldsbrott, har detta projekt varit av stor betydelse för att bygga en tydligare samhällsgemenskap. Alla deltagande företag upplever sig vara med och bygga en ny sådan "anda" i Södertälje. För de stora företagen är engagemanget i Södertälje, just genom kommunens utsatthet, förstås ett sätt att även nationellt kunna visa på att man tar ansvar.

Utöver detta har många av företagen också säkrat sin framtida rekrytering genom projektet.

\subsubsection{Samarbete med andra aktörer}

Telge Tillväxt är i sig ett aktiebolag med många samarbetande delägare. Förutom Södertälje kommun ägs projektet av Manpower, KF, Peab, Mekonomen, Folksam och Scania - alla stora svenska företag. Kommunen är den i särklass största ägaren, men företagens ägare är symboliskt viktig. 
Utöver dessa företag är även Arbetsförmedlingen och bemanningsföretaget Randstad samarbetspartners i projektet. Utöver medfinansiärer och samarbetspartners arbetar Telge tillväxt med en rad andra näringslivskontakter. Totalt rör det sig om ca 80 företag i Södertäljeområdet som har kontakt med projektet och hyr in personal (ungdomar) från projektet. De är med andra ord kunder hos Telge tillväxt.

\subsubsection{Finansiering}

Projektet har en total budget på närmare $20 \mathrm{Mkr}$. Ungefär hälften av finansieringen kommer från EU:s Socialfond, medan andra hälften kommer från Södertälje kommun och från Arbetsförmedlingen. Arbetsförmedlingens medfinansiering sker inom ramen för ordinarie program.

Utöver detta kan man också hävda att de företag som hyr in personal från Telge tillväxt också bidrar till projektets finansiering.

\subsubsection{Framgångsfaktorer}

En viktig del i projektets framgång torde ligga i att ungdomarna erbjuds "en riktig anställning" redan från start. På många sätt betyder detta mycket för de unga. Det ger dem samma möjligheter och rättigheter i samhället som andra med anställning har. Men det skapar också ett ökat incitament att sköta sina uppgifter och ökade möjligheter för Telge tillväxt att ställa krav på ungdomarna.

De viktigaste framgångsfaktorerna för projektet rör dels det sammanhang som ungdomarna sätts i inom Telge tillväxt, och dels den goda kontakten och det upparbetade förtroendet med näringslivet. Enligt representanter för målgruppen har engagemanget från, och tillgängligheten till personal i projektet varit viktigt. Man har också fått utföra ett arbete under den tid man blivit matchad till olika arbetsgivare för att ytterligare öka motivationen och känslan av att man faktiskt kan bidra. En deltagare beskriver det som att ungdomarna genom Telge tillväxt kunnat "motbevisa bilden av ungdomar genom det arbete vi gör" och att arbetssättet inom Telge tillväxt gjort alla mer motiverade och positiva i sitt arbetssökande.

Relationen och förtroendebyggandet med näringslivet har också varit centralt. Genom "rätt" och effektiv matchning har projektet lyckats hitta rätt jobb till rätt person vilket också näringslivet poängterar som en oerhört viktig framgångsfaktor. Från Scanias sida framhålls att liknande matchningsprocesser i andra sammanhang från kommunen och 
Arbetsförmedlingen fungerat mycket sämre. Man har genom Telge tillväxt helt enkelt fătt bättre och mer motiverad personal inhyrd.

\subsubsection{Utvidgning och spridning av projektet}

Denna modell, kallad Telge-modellen, ska kunna spridas till andra kommuner i Sverige. Telge tillväxt har genererat ett enormt intresse nationellt och ett 20-tal kommuner har kommit på besök för att lära om arbetssätt och metodik. Sveriges arbetsmarknadsminister har också besökt Telge tillväxt. Idén från början har varit att utveckla en modell för att arbeta med effektiv matchning av långtidsarbetslösa ungdomar gentemot arbetsmarknaden, och man menar att det resultatet har uppnåtts.

Utmaningen ligger i finansieringen där man i nuläget mottar ESF-stöd för en väsentlig del av kostnaderna och sannolikt kommer att ansöka om en förlängd finansieringsperiod. Förhoppningen är därmed att fortsätta med projektet på längre sikt än vad som är fastsällt idag. Gentemot kommunen har man en bra relation, och därifrån finns ett starkt intresse av att fortsätta finansieringen genom Telge AB. Från Telge tillväxts sida har man också kunnat visa att även om verksamheten drivs med förlust idag, så kan man spara mycket pengar genom att få många fler ungdomar ut på arbetsmarknad och i självförsörjning genom det arbete som görs.

\subsubsection{Källor}

Ranya Said, tf VD, Telge tillväxt.

Aydin Özkaya, arbetsmarknadskoordinator Södertälje kommun (även intervjuad om ICA).

Mikael Englund, HR-chef Rekrytering, Scania.

Intervju med Louise, deltagare i projektet.

\subsection{Unga Jobb}

\subsubsection{Kort om initiativet}

Swedbank är en av Sveriges största banker, med 8 miljoner privatkunder och omkring 500 bankkontor. Banken finns på fyra s.k. hemmamarknader i Sverige, Estland, Lettland och Litauen men har även kontor och verksamhet i flera andra länder. Totalt arbetar över 14000 personer i Swedbank. Swedbank är också samarbetspartner till ett stort antal lokala sparbanker runtom i landet. 
Unga Jobb är en satsning för att erbjuda arbetslösa ungdomar praktik inom företag runt om i landet. Syftet med Unga Jobb är att minska utanförskapet bland ungdomar som står långt ifrån skola och arbetsliv genom att skapa praktikplatser lokalt på personernas egna orter. Genom att erbjuda praktikplatser, och engagera företagskunder och lokala parter, vill Unga Jobb bidra till att minska avståndet mellan unga arbetstagare och arbetsgivare.

Genom sin praktikplats får ungdomarna arbetslivserfarenhet och en fot in på arbetsmarknaden och dessutom får de med sig en värdefull referens. Satsningen innebär även en möjlighet för företagen att arbeta med samhällsengagemang och vara med och bidra till förändring och utveckling.

Swedbank, som varit initiativtagare till satsningen, har haft som mål att fă ut 1000 ungdomar i praktik varje år hos något företag i landet. Tanken var att $10-12 \%$ av dessa praktikplatser skulle återfinnas inom Swedbank, och resterande del hos företag i bankens kundkrets. Bägge dessa mål har uppnåtts och från och med 2013 finns ett nytt mål för företaget om att varje kontor runt om i landet ska ha haft en "ungajobbare" hos sig.

\subsubsection{Resultat}

Sammanlagt har satsningen, sedan den drog igång 2009, skapat över 4 000 praktikplatser varav 550 har varit hos Swedbank och Sparbankerna själva. Av dessa 4000 har mer än hälften fått någon form av anställning på banken efter praktiken.

\subsubsection{Målgruppen}

Satsningen riktar sig till arbetslösa ungdomar mellan 18 och 24 år som är inskrivna hos Arbetsförmedlingen och en del i den s.k. jobbgarantin för unga. Dessa står ofta långt både ifrån arbete och studier och ses därför som en viktig grupp att stödja ur både ett samhälls- och individperspektiv.

\subsubsection{Företagets roll och nytta}

Det nationella initiativet kommer från Swedbank. Lokalt i genomförandet kan dock rollfördelningen och det exakta tillvägagångssättet skilja sig mycket åt. I de flesta fall är det Swedbank som tar initiativ till det lokala arbetet med att dra igång en Unga Jobb-satsning men det finns även exempel på tillfällen då antingen kommunen eller den lokala Arbetsförmedlingen initierat projekt. 
Kommunen tar ofta ledningen i arbetet och Swedbank fungerar då som ett bollplank och är med i styrgruppen. Inledningsvis sker ett förmöte med kommunpolitiker och Arbetsförmedlingens sektionschef. Därefter bjuds det övriga näringslivet, facket och andra berörda organisationer in.

Arbetsförmedlingen genomför sedan matchningen mellan företag och ungdomar och arbetar för att hitta passande praktikplatser och passande praktikanter. Ungdomarna bjuds in till en "kick-off-träff" där fokus ligger på att ge inspiration och grundläggande kunskaper om arbetslivet. Deltagarna utför sedan tre månaders praktiktjänstgörning på företaget och får under tiden tillgång till en handledare.

För såväl Swedbank som andra deltagande företag har det inneburit en breddad rekryteringsbas och bra kontakter samt ny energi och nya infallsvinklar. Swedbank uppger dessutom att medarbetarna är stolta över att arbeta i en bank som engagerar sig i samhällsfrågor och att bankens varumärke har stärkts då satsningen fătt positiv publicitet och uppmärksamhet.

\subsubsection{Samarbete med andra aktörer}

Kraften i Unga Jobb ligger i ett lokalt och brett engagemang med Swedbank, Sparbankerna, Arbetsförmedlingen och kommunerna som huvudaktörer. Swedbank och övriga företag erbjuder praktikplatser. Swedbank är en övergripande initiativtagare, men samverkar med Arbetsförmedlingen och kommunerna. Arbetsförmedlingen och kommunerna deltar vanligen $\mathrm{i}$ arbetet att matcha individer mot praktikplatser. Både Arbetsförmedlingen och kommunerna bidrar till att finansiera individerna under praktiken. Dessutom finns flera lokala aktörer och sammansättningen av dessa är lokalt präglat. Det företag, utöver bankerna, som återfinns på fler håll nationellt och inte enbart i lokala satsningar är bemanningsföretaget Manpower.

\subsubsection{Finansiering}

Finansieringen av insatsen har huvudsakligen Arbetsförmedlingen svarat för, inom ramen för ordinarie program knutna till deltagarna som individer. Även kommunerna bidrar till finansieringen genom att bistå vissa av individerna med ekonomikt bistånd (socialtjänsten). Från Swedbanks håll har insatserna främst bestått i en projektldedare centralt och visst kommunikationsstöd. Framöver är det planerat att lägga mer personella resurser på Unga Jobb och att finansiera dessa internt i banken. 


\subsubsection{Framgångsfaktorer}

Engagemanget har varit stort och det har varit enkelt at få med sig viktiga aktörer så som kommuner, företag och arbetsförmedlingar. Eftersom det handlar om att erbjuda praktikplatser och inte avlönade jobb har det varit enklare för aktörerna att engagera sig; de har vågat satsa och inte varit rädda att förlora på det. En annan faktor som gjort att projektet lyckats och så pass många unga kommit ut i praktik och fått vidare anställning är att projektet är decentraliserat och når personer på deras egna ort och de lokala aktörerna som känner till för-utsättningarna har drivit arbetet. Dessutom täcker projektet hela Sve-rige och alla delar av landet, vilket gjort att många unga har fătt chansen att vara en del av det.

En viktig lärdom från projektet är vikten av att vara tydlig med vad satsningen handlar om och framhålla att det gäller praktik och inte ett löfte om anställning. Där arbetet kört fast har det ofta handlat om otydlighet mellan olika aktörer.

\subsubsection{Utvidgning och spridning av projektet}

Projektet planerar att utvidgas och öka i omfattning från 1000 till 10 000 praktikplatser årligen under två år. Målet är att fler stora företag ska involveras för att på det sättet möjliggöra många fler praktikplatser. Dessutom tas en nationell struktur och handlingsplan fram där arbetet ska bli mer strukturerat. Även om satsningarna fortfarande ska vara lokalt förankrade ska de ändå ske mer på samma sätt över hela landet. Inom Swedbank satsar man även på att avstätta mer resurser till Unga jobb genom att fler personer ska vara delaktiga i satsningen.

Det finns även planer på att bredda målgruppen och hitta en modell för att arbeta med unga utan fullständiga gymnasiebetyg. Tanken är att dessa ska få läsa upp sina betyg två dagar i veckan och praktisera resterande dagar. I denna satsning är planen att även samarbeta med utbildningsaktörer så som Lernia och Folkuniversiteten.

\subsubsection{Källor}

Patricia Kempff, Swedbank.

Ethel Capelle, Scandic Hotels.

Anna-Karin Horney, Kalix kommun.

Soledad Grafeuille, Arbetsförmedlingen. 


\subsection{Yrkesåret Gnosjö}

\subsubsection{Kort om initiativet}

Yrkesåret i Gnosjö är ett pilotprojekt som pågått år 2011-2013. Syftet har varit att bidra till kompetensförsörjning inom industrin genom att utarbeta en kvalitetssäkrad modell för att genom utbildning och praktik göra ungdomar anställningsbara. Avsikten har även varit att förändra rådande system och strukturer på ett sätt som förbättrar förutsättningarna för unga människor att starta en karriär inom industrin. Bakgrunden till initiativet är att tillvekningsindustrin upplever brist på personer med tillräcklig kompetens för att vara anställningsbara även på de minst kvalificerade arbetsuppgifterna. Många ungdomar går arbetslösa samtidigt som industrin inte lyckas rekrytera nya medarbetare. Satsningen på yrkesåret har haft som mål att lösa denna problematik.

\subsubsection{Resultat}

Målet har varit att ta fram en ny och fungerande modell för hur unga arbetslösa ungdomar kan slussas in i fast anställning. En viktig del är utvecklingen av en utvärderingsmodell för kompetenskraven för de lägst kvalificerade jobben och en metod för att säkra att kraven matchar arbetet.

Då arbetet har haft en tydlig pilotkaraktär har man hittills bara arbetat med ett fåtal unga. Endast fyra ungdomar har hittills genomgått hela yrkesåret. Modellen som utvecklades baserades på företagens behov genom att en referensgrupp bestående av representanter från åtta industriföretag arbetade fram kompetenskrav i ett antal steg. Dessa krav skalades sedan ned till en kursplan för 16 veckors utbildning samt mål för praktiktjänstgöringens lärande. Kompetenskraven för utbildningen innehåller både praktiska och teoretiska moment, men även sociala delar som fokuserar på samarbetsförmåga och andra "mjuka" värden.

Utbildningarna har skett på utbildningscenter som handlats upp av Arbetsförmedlingen. Efter 16 veckor har praktiktjänstgörningen påbörjats på något av de involverade företagen och även denna del har setts som en lärandeprocess där ungdomarna ska arbeta efter vissa specifika kvalitetsmål. Under praktikens gång har varje ungdom tillgång till en handledare på företaget samtidigt som en lärare från utbildningen är med och utvecklar arbetsuppgifter som ska motsvara målen. Läraren och handledaren har i uppgift att följa deltagaren och stämma av arbetet mot planen för att försäkra sig om att målen uppfylls och personen blir anställningsbar. Tanken är att så fort deltagaren uppfyller kraven 
om anställningsbarhet ska yrkesintroduktionen övergå i reguljär anställning - även om inte tiden för praktiktjänstgörningen löpt ut.

\subsubsection{Målgruppen}

Målgruppen har varit ungdomar 18-25 år med avslutad gymnasieutbildning. Valet av målgrupp baserades på att detta ansågs stämma överens med företagens rekryteringsbehov och önskade arbetskraft. Ungdomarna hade med sig gymnasieexamen utan teknisk inriktning, och passade därmed för yrkesintroduktionens tekniska utbildningar.

\subsubsection{Företagens roll och nytta}

Även om initiativet kommer från de fyra kommunerna så har det vuxit fram i nära samråd med det lokala näringslivet. Denna region är en region starkt präglad av små och medelstora industriföretag och har av tradition låg arbetslöshet. Banden mellan företagen och kommunerna är ofta mycket nära och starka. Företagen kan därför sägas ha varit pådrivande även om man inte formellt är initiativtagare.

Det är ännu något tidigt att säga något närmare om företagens nytta, då så få ungdomar ännu avslutat yrkesåret. Men, företagen i regionen är av tradition både mycket affärsorienterade och samhällsengagerade. Frågan om de lägsta kvalifikationskraven är en viktig fråga för företagen i Gnosjöregionen. Företagen här söker inte i första hand framstå som ansvarstagande, utan man söker en lösning på en upplevd rekryteringssituation och känner samtidigt ett ansvar för de unga i regionen.

\subsubsection{Samarbete med andra aktörer}

I projketet har fyra kommuner (Gnosjö, Gislaved, Vaggeryd och Värnamo), Fackförbundet IF Metall, Arbetsförmedlingen, samt ett antal företag inom tillverkningsindustrin deltagit. Initiativtagare var Gnosjö kommun som bjöd in de andra aktörerna för att tillsammans arbeta fram en modell för utbildning. I detta arbete var även branschorganisationen teknikföretagen med och tillsammans med IF Metall utvecklade man kompetenskraven för de olika stegen mot anställningsbarhet. Fokus för satsningen låg främst på att utarbeta modellen för utbildningen. Arbetsförmedlingens huvuduppgift var sedan att matcha företagens rekryteringbehov med de ungdomar som anmält sitt intresse för projektet och ville vara med i pilotsatsingen. 


\subsubsection{Finansiering}

Huvudfinansiär för insatsen har varit Regionförbundet i Jönköping med bidrag från Gnosjö kommun. Kommunen har ansvarat för en stor del av kostnaden för förstudien och riggning av projektet. Mindre medfinansiering har lämnats från IF Metall, branschorganisationen Teknikföretagen, samt Gislaveds, Vaggeryds och Värnamo kommuner. Grundidén för finansieringen har varit att använda befintliga resurser hos de olika aktörerna och att inte behöva starta upp nya resurskrävande arbetsgrupper etc. Aktörerna har fokuserat på att använda sig av redan befintliga program men att lära sig synkronisera dessa bättre med varandra.

Arbetsförmedlingen har även bidragit med finansiering för de enskilda deltagare som genomgått pilotinsatsen.

\subsubsection{Framgångsfaktorer}

Det främsta skälet till att man lyckats ta fram en kvalitetssäkrad modell som fătt stor spridning och anses lyckad är att företagens behov har varit drivande. Satsningen har inte fokuserat på att bekämpa ungdomsarbetslösheten i första hand utan på att förbättra rekryteringsmöjligheterna för företagen. Därmed har företagen varit väl förankrade i satsningen redan från uppstart och de har själva arbetat fram mål och krav för ungdomarna och för att dessa ska bli anställningsbara.

Vidare lyfts faktorer som prestigelöshet, engagemang och gott samarbete som skäl till framgång. Satsningen har inbegripit ett nätverk av olika aktörer som alla haft tydliga roller och bidragit med kunskaper och erfarenheter som sammantaget utmynnat $\mathrm{i}$ en heltäckande modell av hög kvalitet. Det bedöms även att målgruppen har passat bra för satsningen och att unga personer med gymnasieutbildning motsvarar företagens rekryteringsbehov.

\subsubsection{Utvidgning och spridning av projektet}

Satsningen har fått stor uppmärksamhet och planerar att rullas ut på flera olika håll. Arbetsmarknadsdepartementet har beslutat att ge Arbetsförmedlingen i uppdrag att vidareutveckla sitt åtagande genom att möjligöra branschanpassad utbildning under yrkesintroduktionsanställningen med målsättningen att totalt 800 ungdomar ska nå anställning. Även andra branscher har visat intresse för modellen och såväl fastighetsbranschen som Industriarbetsgivarna arbetar med att ta fram utbildningar efter samma modell. 
Modellen anses gå att använda på fler håll både nationellt och internationellt. Det gäller att anpassa den efter lokala och branschorienterade förutsättningar men ska kunna appliceras på de flesta kontexter. Eftersom modellen till mycket utgår från arbetsgivarbehoven och att förbättra matchningen mellan arbetstagare och arbetsgivare ska den fungera brett, bara den anpassas efter rådande situation.

\subsubsection{Källor}

Ingegerd Green, Processledare, Gnosjö Kommun.

Stefan Larsson, Projektledare, Gnosjö kommun.

Mattias Yström, Arbetsförmedlingen.

Annelie Borgström, IF Metall.

Tobias Svensson, Bufab.

Tomas Pettersson, Skärteknikcentrum. 


\section{De finske cases}

\subsection{Läroavtalskampanjen "nappaa nuori töihin" (Plocka in ungdomen till arbete)}

\subsubsection{Kort om initiativet}

Läroavtal är en sedan länge etablerad metod för att varva teoretisk utbildning med praktik, lärlingsplats. Metoden används i nära samverkan mellan skola och arbetsliv. Systemet med läroavtal kom till Finland på 1970-talet, med inspriation från det tyska lärlingssystemet. Ungdomarna studerar under cirka $20 \%$ av tiden, medan resterande tid sker i form av avlönat lärlingsarbete på en arbetsplats. Även den delen som rör undervisningen sker $\mathrm{i}$ mer anpassade former än i skolan. Utbildningarna är vanligen mellan 1-2,5 år, beroende på inriktning och nivå. Kompletterande yrkesutbildningar är ofta kortare medan basutbildningarna är längre.

I september 2011 startade läroavtalsutbildningsbyråerna i Egentliga Finland en särskild kampanj riktad till arbetsgivarna i regionen. Syftet var att tydligare göra regionens arbetslösa 17-24-åringar till målgrupp för sysselsättning via läroavtalen. Idén till Nappaa Nuori Töihinkampanjen föddes inom läroavtalsbyrån, men den fick sin slutliga utformning först efter en nära dialog med med arbets- och näringsbyrån (senare TE-Byrån). Genom det nya samarbetet har man genomfört vissa anpassningar av läroavtalen. Det som är nytt i detta projekt är kopplingen mellan de praktikplatser företagen annars erbjuder unga arbetslösa, läroavtalsutbildningen och möjlighet till anställning därefter.

Istället för att företagen som annars ta emot unga arbetslösa för en kortare praktik (vanligen cirka 2 månader) försöker man i projektet slussa de unga vidare från praktiken in i läroavtalsutbildningen. På så sätt får de unga möjlighet att komplettera sin utbildning och samtidigt behålla sin kontakt med det företag man gjort praktik på. Detta stärker både de unga, samtidigt som det ökar möjligheterna att de unga och företagen skall "finna varandra" för en möjlig framtida anställning.

TE-byrån förmedlar kontakten mellan Läroavtalsbyrån och företagen. TE-Byrån kan också ge stöd kring vilken typ av lönesubventioner och liknande som kan vara aktuell för olika ungdomar. 


\subsubsection{Resultat}

Målet för initiativet var att få in 120 arbetslösa ungdomar i läroavtalsutbildning. Målet överträffades, genom att hela 193 ungdomar i målgruppen kommit att ingå i läroavtalsmodellen vid slutet av 2012, räknat på projektets totala 16 månader.

Totalt deltog hela 190 företag. Majoriteten av ungdomarna, $60 \%$, sysselsattes (genom läroavtal) hos företag med mindre än 10 anställda och $26 \%$ hos företag med 10-49 anställda.

Kampanjen har fått mycket positiv uppmärksamhet och samarbetet har varit bra med lokala tidningar som gärna skrivit om "solskenshistorier" där ungdomen och företaget i fråga varit i fokus.

\subsubsection{Målgruppen}

Projektets målgrupp är arbetslösa ungdomar 17-24 år, med varierande bakgrund. I en del fall har man avslutat gymnasium eller yrkesutbildning, men är ändå av olika skäl inte är anställningsbar. I andra fall har man inte förmått avsluta sin utbildning. Samtliga deltagare är registerade som arbetslösa hos TE-byråerna.

\subsubsection{Företagens roll och nytta}

Företagens roll har i första hand varit att ta emot praktikanter, lärlingar, med syfte också att kunna erbjuda dem anställning efter avslutad utbildning. Det nya för företagen är att målgruppen är något annorlunda, genom att man tydligare addresserar arbetslösa som står relativt långt från arbetsmarknaden. Detta har också gjort att mindre företag har kommit mera i fokus för läroavtalsmodellen än vad som tidigare varit fallet.

Företagen kan inte sägas ha varit initiativtagare eller drivande i detta projekt. Det är snarast så att man ifrån de övriga aktörerna har fått anstränga sig för att fă företagen engagerade. Däremot har den upplevda nyttan hos de deltagande företagen varit betydande. Företagen har också fătt god publicitet kring sitt sociala ansvarstagande, vilket man i många fall bedömt som mycket värdefullt. 


\subsubsection{Samarbete med andra aktörer}

Drivande aktör är således de s.k. läroavtalsutbildningsbyråerna. Projektet genomförs i nära samverkan mellan dessa, den statliga arbetsförmedlingen samt de företag som är engagerade i att erbjuda platser.

\subsubsection{Finansiering}

I finansieringen ingår att företagen kan få upp till 1000 EUR i stöd per månad för att ta sig an ungdomar under läroavtalsutbildning. Stödet här är detsamma som tidigare i läroavtalskampanjen. Merparten av stödet kommer från TE-Byrån och en mindre del från Läroavtalsbyrån. Företagen kan också få stöd i form av administrativ hjälp för att söka läroavtal.

\subsubsection{Framgångsfaktorer}

Det fördjupade samarbetet mellan myndigheterna var en utmaning. Skyddet av personuppgifter är starkt och myndigheter får normalt inte dela information om enskilda, inte ens till andra myndigheter. Här var man tvungen att hitta särskilda vägar för att hantera denna fråga. Att man klarade av att lösa denna problematik har varit en viktig del i projektets framgång.

En andra utmaning handlar om att löroavtalen inte är särskilt kända. Detta har man motverkat genom utveckla informationsmaterialet, regelbundna koordinerade träffar med ungdomar som är TE-Byråns kunder samt genom att söka kontakt med skolornas studiehandledare som tidigare sällan om alls nämnde möjligheten med läroavtal för de ungdomar som är i färd med att avsluta sin grundutbildning.

Från projektet kan man hittills dra följande slutsatser:

- Man behöver inte alltid utveckla nytt - det går bra att pröva gamla metoder men att använda dem på nya sätt.

- Samverkan mellan olika aktörer är avgörande - den behöver vara enkel och informell.

- Det är viktigt att aktivt bearbeta företagen och att hjälpa ungdomarna att marknadsföra sig själva och läroavtalsutbildningen, hjälpa dem att lägga fram fördelarna för företagen.

- Kommunikation och medvetandegörande är a och o. Företagens kännedom om läroavtal är en flaskhals som måste bearbetas. Den statliga ungdomsgarantin ger stora möjligheter då den bibehåller allmänhetens fokus på ungdomsfrågorna och hjälper till att göra läroavtalen mer kända. 
Den kanske största framgångsfaktorn handlar om det som är det nya i projektet. Nämligen att knyta samman praktikplatserna med läroavtalen. Läroavtalen innebär ett stort åtagande från såväl ungdomarnas som företagens sida. Genom att de unga först har genomfört praktik hos arbetsgivarna har bägge fått en möjlighet att bättre lära känna varandra.

Ungdomarna själva menar att modellen är lyckad. De tydligaste resultaten uppnås oftast för de lite äldre ungdomarna - de över 20 år. För de yngre handlar det oftast om att öka deras kunskap om hur arbetslivet fungerar.

\subsubsection{Utvidning och spridning av initiativet}

Redan under projekttiden (fram till slutet av 2012) har verksamheten successivt vuxit, till att omfatta fem kommuner inom Egentliga Finland (Reso, Nystad, Loimaa, Salo och Forssa). Dessutom har kampanjen presenterats i ett seminarium av OPSO ry (Suomen Oppisopimuskoulutuksen Järjestäjät Ry = Finlands förening för läroavtalsorganisatörer) $\mathrm{i}$ november 2012. I början av 2013 startades det nationella Ungdomsgarantikampanjen som förväntas leda till det att även andra läroavtalsorganisatörer börja bygga upp sina lokala samarbetsnätverk och utnyttja Åboregionens goda erfarenheter och lärdomar.

Läroavtalsinstitutionen är relativt unik för Finland, även om liknande insatser förekommer även i andra nordiska länder. På ett mer generellt plan finns förstås möjligheter att ta till sig erfarenheter, såsom t.ex. när det gäller kombinationen av praktik och arbetsplatsförlagd utbildning. En gemensam erfarenhet från de nordiska länderna är att många av de unga arbetslösa har en ofullständig utbildning och de har inte förmått att avsluta denna med ordinarie stödinsatser. En insats som integrerar arbetspraktik, utbildning och möjligheter till subventionerade anställningsformer för unga kan därför vara ett viktigt komplement. Att ge företagen en mer långsiktig roll i de ungas utveckling är också viktigt i detta sammanhang.

\subsubsection{Källor}

Esa Anttila, koulutustarkastaja (utbildningsinspektör), Åbo läroavtals-byrå.

Katre Saaremäel, sakkunnig/lärandeutveckling/ungdomsservice, Arbets- och näringsbyrån.

Sarianna Saurén, läroavtalselev, General Logistics Finland.

Merja Pohjola, enhetschef, General Logistics Finland. 


\section{2 "Uusien mahdollisuuksien tori" (Nya möjligheternas torg, UMT) i Kuopio}

\subsubsection{Kort om initiativet}

Initiativet till projektet kom ursprungligen från frivilligorganisationen (NGO) för ungdomars integrering i det finska samhället - Yllätetään yhteiskunta (Låt oss överraska samhället). På ett tidigt skede involverades även Kuopio stad och företagarföreningen i Kuopio - Kuopion yrittäjät (Kuopios företagare).

Projektets övergripande syfte har varit att stimulera företagen att sporra varandra till att anställa unga arbetslösa. Projektets metoder i genomförandet har handlat om att matcha och stödja unga gentemot företag på ett mer aktivt sätt än som sker inom de normala insatserna från aktörerna.

Insatserna inleddes vanligtvis med ett möte mellan Kuopio stads sysselsättningsenhet (TY) och den arbetslösa unga individen. Syftet med mötet var att kartlägga intresse och förutsättningar hos den unga. Därpå sökte TY kontakt med lämpliga företag och förmedlade kontakten mellan den unga arbetssökande och företagen. Företagarföreningen har också varit aktiva i att förmedla kontakterna till lämpliga företag. En del av förmedlingen sköttes också via en för projektet gemensam Facebook-sida.

\subsubsection{Resultat}

Kampanjen hade som mål att sysselsätta 700 ungdomar under ett år. Totalt kom initiativet att omfatta 271 unga. Av dessa kunde 33 personer få en anställning som ett resultat av projektet, 39 skaffade själva anställning under projekttiden. För ytterligare ett 30-tal unga kunde andra lösningar, såsom studier, erbjudas.

Sammanfattningsvis kan det konstateras att fastän projektets faktiska genomförande och utfall inte motsvarade ursprungliga förväntningar eller upplägg, kom flera gynnsamma processer igång under den korta projekttiden. Dessa idéer och nya sätt att motverka ungdomsarbetslösheten lever vidare i de nya initiativ som kommit igång efter projektet. De viktigaste lärdomarna kan koncentreras i följande punkter:

- Vikten av långvarig satsning på publicitetsarbetet.

- Koordinering mellan olika instanser är nödvändigt.

- Ständig direktkontakt med företagen ger rätt perspektiv och infallsvinkel för den offentliga sektorns satsningar. 
- Alla ungdomar kan inte motiveras till och är inte heller villiga till traditionellt deltagande i arbetsmarknaden i form av varaktig heltidsanställning.

\subsubsection{Målgruppen}

Målgruppen för projektet har varit unga arbetslösa i Kuopio stad. Projektet har vänt sig brett till målgruppen unga (17-24 år), vilket resulterat i att en relativt stor del av projektdeltagarna varit okända för arbetsförmedlingen (TE-byråerna). För att dessa skall kunna delta har de dock varit tvungna att registrera sig som arbetssökande hos arbetsförmedlingen.

Detta är en faktor värd att notera, nämligen att alla unga arbetslösa inte är kända av myndigheterna (vid en svensk studie nyligen konstaterades att en relativt hög andel unga varken arbetade, studerade eller var inskrivna som arbetssökande).11

\subsubsection{Företagens roll och nytta}

Inititativet till projektet utvecklades i nära samverkan med frivilligaorganisatioionen för unga - Yllätetään yhteiskunta (Låt oss överraska samhället) - och Kuopios företagarförening - Kuopion yrittäjät (Kuopios företagare). Även Kuopio stad var tidigt involverad i projektet.

Att företagen skulle vara aktiva och drivande och "peppa" varandra ansågs redan i projektets utformning vara viktigt. Projektet utvecklades som ett resultat av de goda kontakter med näringslivet i Kuopio som man hade i Yllätetään yhteiskunta.

I genomförandet är det sedan i första hand Kuopio stad och dess sysselsättningsenhet som svarat för merparten av det praktiska genomförandet.

Samtidigt har de deltagande företagen varit helt avgörande för att projektet skulle lyckas (även om målen inte nåtts ännu). En central del i projektet har varit att företagen skulle tävla sinsemellan om att ta sig an arbetslösa unga.

En ytterligare viktig faktor i genomförandet av projektet var synligheten i media. Genom synligheten i lokal tidningspress, radio och TV ökad medvetandet om kampanjen. Företagen fick använda projektets kampanjmaterial med kvalitetsstämpel och logo "ansvarsfull arbetsgivare" i sin marknadsföring. I och med att temat var så angeläget, fick

11 Ungdomsstyrelsen, Temagruppen Unga i arbetslivet, rapport 2012:4. 
kampanjen mer synlighet än administratörerna hade räknat med. Samtidigt betonades hur viktig synligheten var för att kampanjen kunde genomföras. Efter varje rapportering i media kom det omedelbart fler ansökningar från ungdomar. Det måste dock påpekas att den aktiva projekttiden på 10 månader begränsade möjligheter att samla "synlighetskapital" för initiativet och för de deltagande företagen.

\subsubsection{Samarbete med andra aktörer}

Projektet har letts av Kuopio stad. Även initiativtagaren - Yllätetään yhteiskunta - och det lokala näringslivet genom företagarföreningen Kuopion yrittäjät - har varit drivande bakom projektet. TE-byråerna har också varit en viktig aktör i projektet.

Möjligen kan man hävda att projektet kommit att drivas och genomföras av Kuopio stad i något högre utsträckning än vad som från början hade varit tänkt.

\subsubsection{Finansiering}

Den huvudsakliga finansieringen av projektet har skett genom de ordinarie programmen för arbetslösa unga. Härigenom har såväl TEbyråerna och kommunen blivit viktiga aktörer.

\subsubsection{Framgångsfaktorer}

Flera av intervjuade vittnade om att de offentliga myndigheterna i Kuopio tack vare projektet upptäckt fördelen med att samarbeta mera direkt med företagen och företagarorganisationerna.

Det som upplevdes som positivt av projektkoordinatorerna var att man inte använde finansiering från ESF eller liknande EU-fonder, eftersom de administrativa kraven i så fall hade blivit avsevärt större. Man misstänkte också att EU-projekt med egen administration skulle ha kunnat försvåra koordineringen i sysselsättningsfrågorna.

\subsubsection{Utvidgning och spridning av initiativet}

Detta projekt är ett relativt typiskt samarbete mellan myndigheterna och näringslivet. Det som vi menar gör projekt intressant är behovet av publicitet kring projekten, både för att faktiskt locka företag och unga till projektet men också som ett sätt att motivera företagen att delta. 
Vi menar att projektet och dess erfarenheter relativt lätt kan spridas till andra städer eller länder.

\subsubsection{Källor}

Hanna Kepponen, expert i sysselsättningstjänster, Kuopio stad, syssel-sättningsenhet. Anssi Kuikka, företagssamarbetskoordinator, Kuopio stad, sysselsättningsenhet. Juha Kankaanpää, varuhuschef, Motonet.

Jaakko Nuotio, verksamhetsledare Nuorten palvelu ry. (Ungdomsservice r.f.).

Kirsi Sisso-Litmanen, verksamhetsledare, Kuopion Yrittäjät (Kuopios företagare).

\subsection{Vastuullinen Kesäduuni (Ansvarsfullt sommarjobb, VKD)}

\subsubsection{Kort om initiativet}

Barn- och ungdomsstiftelsen i Finland (SLNS) har som övergripande mål för sin verksamhet att stärka ungdomarnas livskunskaper och bygga broar mellan samhällets olika aktörer. Den stora nationella mediakoncernen, Alma Media, kände till SLNS tidigare goda samarbete med näringslivet och ville hitta nya sätt för att främja ansvarsfullt företagande. Härigenom identifierades ungas sysselsättning som en viktig fråga.

Alma Media och SLNS skapade därför tillsammans en kampanj med fokus på ungdomars möjlighet till sommarjobb (Vastuullinen kesäduuni). Kampanjens verksamhet har utvecklats under hela kampanjtiden. Kampanjen har nu pågått i tre år sedan 2011. Antalet företag och unga i kampanjen har vuxit för varje år allteftersom initiativets synlighet har ökat.

Målet är i första hand att skapa sommarjobb för ungdomar mellan 16 och 25 år och härigenom förbättra deras beredskap och möjligheter att övergå från studier till arbetsliv. Även om sommarjobben inte är en varaktig sysselsättning så bidrar de till att skapa en viktig brygga mellan utbildning och arbetsliv, vilket kan få både direkta och indirekta konsekvenser som påverkar de ungas framtida möjligheter på arbetsmarknaden.

Företagen motiveras av att om man uppfattas som en ansvarsfull arbetsgivare, så kan detta också användas på ett positivt sätt inom såväl deras interna såväl som externa marknadsföring. Anställda med egna barn känner sig stolta och engagerade då deras arbetsgivare visar intresse för ungdomarna. Företagens rykte som ansvarsfull arbetsgivare kan också vara till nytta vid rekryteringen i övrigt liksom också i andra sammanhang. Det är också gynnsamt för företaget att få tillgång till sommarjobbare som på sikt kan rekryteras till företaget. 


\subsubsection{Resultat}

Sammantaget har de företag som deltagit i kampanjen erbjudit mellan 16000 och 35000 sommarjobb årligen. Det är däremot svårare att mäta hur många sommarbjobb har blivit till tack vare kampanjen. Kampanjens omfattning har vuxit under de tre år som den pågått. Tabellen nedan sammanfattar de omedelbara resultaten av initiativet.

\begin{tabular}{lrr}
\hline ÅR & Antal deltagande arbetsgivare & Antal sommarjobb $^{12}$ \\
\hline 2011 & 74 & 16000 \\
2012 & 107 & 30000 \\
2013 & 174 & 35000 \\
\hline
\end{tabular}

Initiativet har även haft tydliga mål beträffande den kvalitet som sommarjobben skall ha. Detta har uttryckts i den manual för "bra sommarjobb" som tagits fram för arbetsgivare och sommarjobbare. Båda parter kan genom denna kolla hur principerna för ett bra sommarjobb bör se ut och kan förverkligas i deras specifika fall. De ledande fem principer är följande:

- Meningsfullt arbete och skälig lön.

- Bra ansökningserfarenhet.

- Tillgång till introduktion och handledning.

- Rättvis och jämlik behandling.

- Skriftligt arbetsavtal och arbetsbetyg.

Kampanjens resultat har även mätts med hjälp av enkäter bland de deltagande företagen. De senast tillgängliga resultaten från år 2012 visar att:

- Företagens anställda inte alltid kände till hur rekryteringsprocessen i företaget sköts: 25 \% visste inte om man berättar för den jobbsökande hur lång tid anställningsprocessen förväntas ta

- Företag som ger stöd till chefer i handledningen av ungdomar informerar bättre om rekryteringsprocessen än företag där cheferna inte får stöd i handledningen av ungdomar

- Var femte företag ger inget särskilt stöd för chefer i bemötande och behandlingen av ungdomarna

- Hos $65 \%$ av företagen finns det allmänna råd för behandling av anställda.

12 Uppgifterna baserar sig på arbetsgivarnas egna uppgifter. 
Ungdomarna har i sina kommentarer bl.a. lyft fram att introduktion av jobben kunde förbättras och att man önskar mer feedback om sitt arbete. Överlag har kampanjen dock fått mycket positivt gensvar hos de sommaranställda som besvarat i kampanjenkäten.

\subsubsection{Målgruppen}

Målgruppen för kampanjaktiviteterna är relativt bred, i princip alla arbetsgivare som anställer ungdomar i sommarjobb. Både företagen och ungdomarna drar nytta av initiativet, men samtidigt kan man säga att insatsen i högre grad gynnar unga som annars skulle ha svårare att ordna sommarjobb på egen hand, och att dessa i förlängningen också är de som kommer att möta en större utmaning även när det gäller att söka och få reguljära jobb. Dessutom gynnas alla om man lyckas förbättra företagens bemötande av ungdomar och höja sommarjobbens kvalitet.

\subsubsection{Företagens roll och nytta}

Alma media och några av de andra partnerföretagen spelar en viktig roll för projektet och dess genomförande. Genom sitt engagemang och sin finansiering möjliggör de projektet. Sammantaget är flera hundra företag/arbetsgivare involverade och bereder unga möjligheter till sommarjobb.

Den konkreta nyttan för företagen handlar kanske i första hand om att företagen får en möjlighet att visa upp sitt sociala ansvarstagande. Men i förlängningen skapar aktiva arbetsgivare förstås också en positiv bild hos de unga som ska bli deras framtida medarbetare.

\subsubsection{Samarbete med andra aktörer}

Projektet genomförs i sin helhet av SLNS. Samarbete finns dock kring finansieringen som i sin helhet sker med privata medel från sponsorföretagen, där ALMA media både spelar en viktig roll som finansiär och som länk till andra sponsorer.

Kampanjchefen är anställd hos SLNS och ansvarar för genomförandet av kampanjen. Hos huvudpartners finns namngivna personer som tillsammans med kampanjchefen utgör styrgruppen. Dessa möts med jämna mellanrum för att diskutera idéer och fatta beslut angående kampanjen. Huvudpartners deltar alla aktivt i den långsiktiga utvecklingen av kampanjen.

Som huvudpartners deltar flera näringslivs- och fackorganisationer: Taloudellinen tiedotustoimisto TAT, Elinkeinoelämän keskusliitto EK, 
Viestinnän ammattilaiset ProCom ry, Henkilöstöjohdon ryhmä HENRY ry, Suomalaisen Työn Liitto, Toimihenkilökeskusjärjestö STTK, Suomen ylioppilaskuntien liitto SYL ry, Suomen ammattikorkeakouluopiskelijakuntien liitto SAMOK ry, Suomen Ammattiin Opiskelevien Liitto SAKKI ry.

Efter kampanjstarten har antalet partners ökat och det har också dykt upp nya, mer lokala initiativ som har många likheter med VKD. Detta är kanske en följd av att det är svårt att inkludera alla viktiga lokala ingredienser i en kampanj vars huvudsäte finns i huvudstadsregionen. Det har dock inkluderats nya element som coachning och seminarier för potentiella "sommarsysselsättare" ute i regionerna.

Hittills har den offentliga sektorn inte varit en aktiv partner i kampanjen. Man har dock inte medvetet utelämnat offentliga aktörer från kampanjens styrgrupp, det har bara blivit så. Men nya kontakter har också knutits som framöver kan komma att leda till nya kampanjaktiviteter som är särskilt inriktade mot arbetsgivare och arbetsplatser inom den offentliga sektorn.

\subsubsection{Finansiering}

Även om projektet är omfattande är kostnaderna för genomförandet begränsade. Totalbudgeten för 2013 års kampanj ligger kring 70000 EUR.

Projektet finansieras i sin helhet med privata medel, där Alma media utgör en huvudfinansiär, och också länk till övriga finansiärer.

\subsubsection{Framgångsfaktorer}

En lärdom som de kampanjansvariga lyfter fram är vikten att ha ett genomtänkt publiceringsmaterial och en tydlig offentlighetsstrategi. Dels måste kampanjmaterialet vara professionellt utformat, dels måste man ha partners som kan erbjuda sina egna kanaler till förfogande, annars måste man ha en mycket större marknadsföringsbudget. Eller så måste man acceptera att kampanjen inte syns i mediabruset - och därmed blir också resultaten mer blygsamma. I VKD:s fall hade man både mediahus såsom privata arbetsförmedlingsföretag med i kampanjen. Värdet av deras bidrag uppskattades vara mångdubbelt högre än kampanjens penningmässiga budget.

Det som också lyfts fram som lyckat är att en positiv framtoning i kampanjbudskapet betydligt underlättar möjligheterna att skapa det nödvändiga engagemanget hos företagen. Dessutom är kampanjens budskap något som berör många. Andra lyckade drag var att involvera en 
grupp personer vars ansvarsområde är Human Resource Management. Detta skedde genom att involvera deras branschorganisation som sakkunnigpartner samt genom att involvera företagens HR-personal. De kampanjansvariga ansåg även att det var lyckat att ha med större företag som viktiga partners eftersom de har mer resurser att satsa på åtgärder som förbättrar kvaliteten på sommarjobben. Dessa företag kan genom sitt exempel entusiasmera och få andra företag att följa deras goda exempel. En annan viktig yrkesgrupp är kommunikationsexperter vars branschorganisation deltar i kampanjen som sakkunnigpartner.

En utmaning för projektet var konjunktursituationen som initialt under år 2011 såg bättre ut då finanskrisens första fas började ebba ut. Men i och med euroländernas skuldkris blev det snart klart att kampanjen inte enbart kunde baseras på ett löfte om fler sommarjobb, den måste kompletteras med ett budskap om behovet att höja sommarjobbens kvalitet. Detta har också visat sig vara ett lyckat drag.

\subsubsection{Utvidgning och spridning av insatsen}

Ett ytterligare mål för kampanjen har varit att nå större geografisk och antalsmässig täckning/spridning av sommarjobben, uppskattningsvist täcker 2013-årets kampanj dryga 10 \% av alla sommarjobb i Finland. För närvarande kommer de flesta deltagande företagen från huvudstadsregionen.

En framtidsvision är även att kampanjlogon skall uppfattas som kvalitetsstämpel för de deltagande företagen. Detta skulle också kunna lugna ungdomarnas föräldrar som då vet att deras barn är i säkra händer då företaget innehar kampanjlogon. Men om man skulle sträva efter någon sorts "certifiering" skulle de administrativa kraven öka avsevärt för att kunna kontrollera kvaliteten av arbetsplatserna. Hittills har kampanjen därför förlitat sig på företagens egenanmälan och endast i några få fall har det behövts ta kontakt med företag vars sommaranställda gett en särskilt tydlig negativ feedback.

En långtidig vision som kampanjen också har är att medverka till att det finska sättet att ta hand om sommaranställda i framtiden skall bli lika kännetecknande för Finland som andra positiva kulturella markörer som t ex bastu, bryggdans och orörd natur. 


\subsubsection{Källor}

Anne Virtanen, Suomen lasten ja nuorten säätiö (Barn- och ungdoms-stiftelsen i Finland, SLNS).

Antti Järventaus, Suomen lasten ja nuorten säätiö (Barn- och ungdomsstiftelsen i Finland, SLNS).

Terhi Huttunen, Sonera (partnerföretag).

Riikka Poukka, Alma Media (partnerföretag).

Henry Grönfors, Sonera (f.d. sommaranställd).

Emil Elo, Alma Media (sommaranställd).

\subsection{Duunita Mut! (Ge mig ett jobb!)}

\subsubsection{Kort om initiativet}

Kalevakoncernen (ett större mediaföretag som bl.a. äger ett flertal dagstidningar i norra Finland) hade tidigare deltagit i diskussioner om att något borde göras åt ungdomarnas situation i Uleåborgstrakten, en region som tack vare universitetet och andra lärosäten har fler ungdomar än på många andra håll samtidigt som ungdomsarbetslösheten också har varit och är hög. Dåliga karriärutsikter ökar risken att förlora duktiga ungdomar till t.ex. huvudstadsregionen.

Kalevatidningens websida (koncernens största tidning) fungerar som kampanjens mötesplats för ungdomar och företag. De unga arbetssökande kan lämna en intresseanmälan om jobb och berätta om sig själva, lägga till ett foto etc. Likaså kan företagen lämna platsannonser på websidan. Duunita Mut! (Ge mig ett jobb!) -sidorna innehåller även annat relevant material om hur man kan söka jobb. Där finns också länkar till relevanta arbetslivsmyndigheter, rådgivningstjänster om yrkesval samt till flera olika arbetsförmedlingstjänster på webben. Dessutom finns information om olika sysselsättningsstöd för de företag som sysselsätter ungdomar.

En viktig del i initiativet är en särskild tjänst där företagen kan utmana varandra i förmågan att sysselsätta ungdomar. Företagen får via initiativet positiv respons och synlighet i media och kan därför dra till sig fler arbetssökande ungdomar. Kampanjorganisationen väljer varje år ut "årets sysselsättare" (Vuoden Duunittaja), ett företag som sedan uppmärksammas extra både i den vanliga papperstidningen och på kampanjens webbsida. Tidningen producerar även andra artiklar och annonser om kampanjen. Kampanjen har även en egen Facebook-sida.

De företag som deltar i kampanjen förbinder sig att sysselsätta en eller flera ungdomar under åtminstone tre månaders tid. Företagen förbinder sig att agera som en rättvis arbetsgivare och att ge ungdomarna 
en positiv bild av arbetslivet och om sin egen bransch. Det är inte meningen att sysselsätta ungdomar i uppgifter från vilka man nyligen avskedat folk. Kampanjen har nu inlett sitt tredje verksamhetsår. Varje år beslutar företaget om kampanjen skall fortsättas eller inte.

\subsubsection{Resultat}

År 2011 deltog 31 företag i kampanjen. Det året var kampanjmålet att sysselsätta 540 unga. Det blev 550, vilket motsvarade över $30 \%$ av alla arbetslösa arbetssökande under 25 år i Uleåborg. Nästan 200 ungdomar lämnade sin intresseanmälan på kampanjens webbplats. Till "årets sysselsättare" (Duunittaja) 2011 utsågs bilverkstaden Kalevan autokorjaamo (Keränen, 2012). Till årets sysselsättare 2012 valdes kollektivt flera av Uleåborg-regionens telemarketingbolag. Kampanjen uppmärksammades under sitt första år även i pressens egen riksomfattande facktidning Suomen lehdistö. Uleåborgs stads utvecklingsprogram "100 tekoa Oulusta" (100 initiativ från Uleåborg) lyfte fram kampanjen som en viktig insats som också lyckats förbättra utveckling och välfärd i regionen.

De inspirerande resultaten ledde till att kampanjen har fortsatt. Under 2012 sysselsatte man enligt egna webbaserade kalkyler ca 400 ungdomar och ca 20 företag deltog. Webkalkylen baserar sig på egenanmälan från företagen. Det har dock visat sig svårt för företagen att uppskatta vilka anställningar som skall eller kan hänföras just till kampanjen. De företag som deltar i kampanjen kan sysselsätta hundratals ungdomar och anställer därför dessa via många olika kanaler.

Företagens gensvar till kampanjen har överlag varit mycket positivt. Det har inte heller framkommit några negativa reaktioner på det sociala tryck som kampanjen med företagsutmaningar (i förmågan att anställa ungdomar) skulle kunna tänkas medföra. Alla är ju medvetna om hur viktigt det är att främja ungdomarnas inträde till arbetsmarknaden.

\subsubsection{Målgruppen}

Målgruppen för initiativet är relativt brett definierad, dvs. unga arbetslösa i Uleåborgsregionen.

\subsubsection{Företagens roll och nytta}

Den enskilt viktigaste aktören i projektet är förstås Kalevakoncernen. Samtidigt kan man hävda ett ett stort antal lokala och regionala företag också tar en aktiv om än inte ledande roll i arbetet. 
Vill man hårdra Kalevakoncernens roll kan man hävda att företaget har övertagit en del av TE-Byråns (Arbetsförmedlingens) uppgifter, nämligen att matcha arbetssökande och arbetsgivare och faktiskt också förmedla arbetstillfällen. Genom att utnyttja den mötesplats för såväl unga som arbetsgivare i regionen som tidningens webbplats utgör, och genom att addera nya innovativa metoder, har tidningen som det verkar förmått att effektivisera arbetsförmedlingen för unga arbetslösa.

För Kalevatidningen är detta förstås också ett sätt för tidningen att befästa sin status som lokalt förankrat medieföretag. Genom kampanjen lockar man återkommande besökare till webbsidan. Kampanjen för samman två av de kanske viktigaste målgrupperna för den som vill annonsera, unga och företagare.

De företag som anställer genom initiativet fyller förstås också var och en viktig roll, genom att bereda unga möjligheter till anställning. Viktigast för de deltagande företagen är den positiva publicitet som sysselsättningsnotiserna och tidningsartiklarna medför. Utöver de positiva effekterna på den externa publiken gynnar en positiv företagsimage även företagen intern då de anställda kan känna sig stolta över sin arbetsgivare. Utöver de publicitetskanaler och tidsresurser som personalen sätter in i kampanjen vid sidan om sina andra uppgifter, har man inte haft några andra resurser. Detta har kanske varit aningen begränsande vad gäller omfattningen av aktiviteter.

\subsubsection{Samarbete med andra}

Även om Kalevakoncernen och tidningen har varit huvudaktören i detta initiativ så är förstås myndigheterna också viktiga. Men de är viktiga genom att göra sitt ordinarie jobb, inom ramen för projektets genomförande.

Kaleva var från början angelägen om att få staden (Uleåborg) med från början. Men det offentliga beslutsfattandet gick dock för långsamt för Kaleva, varför man beslöt att starta upp kampanjen på egen hand. De kampanjansvariga har upplevt att processen har lärt dem en hel del om förutsättningarna för samarbetet mellan företag och den offentliga sektorn.

\subsubsection{Finansiering}

Kampanjresurserna har Kaleva stått för. Normala finansiella resurser från TE Byrån och från kommunerna har förstås också kunnat nyttjas för att stödja företagens anställningar av unga. 


\subsubsection{Framgångsfaktorer}

Den enskilt viktigaste framgångsfaktorn för projektet är den kraft som finns i att flytta arbetsförmedlingsuppgifterna till en webbplats som har många besökare, som primärt inte besöker platsen för att söka arbete eller arbetskraft. Betydelsen av synlighet för företagen framgår väldigt tydligt i detta projekt.

\subsubsection{Utvidgning och spridning}

Kaleva-koncernens kampanjansvariga har deltagit i olika rundbordsdiskussioner, seminarier och andra arrangemang och informationstillfällen där de berättat om sina positiva erfarenheter. De vill framhålla att företagen kan genomföra viktiga samhällsinriktade kampanjer utan tilläggsresurser från den offentliga sektorn om man bara lyckas engagera varandra. I norra Savolax-regionen har man i början av 2013 också startat kampanjen "Nuoret Duuniin" (Ungdomarna till jobben) som har flera gemensamma drag med Duunita Mut!-kampanjen.

Även i Savolax är det en tidning, Savon Sanomat, som erbjuder kanalen till kampanjen på sin websida. Skillnaden jämfört med Kaleva är dock att den här kampanjen finansieras med offentliga medel (Siilinjärvi kommuns, statliga resurser och ESF-medel), och den ansvariga genomförandeorganisationen tillhör kommunala sektorn. Även Nylands förbund (ett kommunalförbund) i huvudstadsregionen har tagit till sig idén med företagsutmaningar i förmågan att sysselsätta ungdom i sin nya kampanj "Kesäduuni Uudellamaalla 2013" (Sommarjobb i Nyland), ett initiativ som i sin tur ser ut att vara en kombination av "Duunita Mut!" och "Vastuullinen kesäduuni" (se vår case-redovisning!)-kampanjerna.

Det torde finnas goda förutsättningar för mediaföretag att ta aktiva initiativ i frågan även på andra håll i Finland (och Norden).

\subsubsection{Källor}

Jaana Ojala, projektchef, Kaleva-koncern.

Heikki Nurmi, Kundrelations- och utvecklingschef, Kaleva-koncern.

Minna Savikko, personalchef, Arina-koncern.

Övrig källa: Keränen, Henna (2012): Unga i Servicen - God Praxis för främjande av ungdomsgarantin, Arbets- och näringsministeriet. 


\section{De islandske cases}

\subsection{Job Forum Reykjavík (Atvinnutorg í Reykjavík)}

\subsubsection{The initiative in brief}

This cooperation project was initiated in February 2012 by the Directorate of Labour, The department of welfare in Reykjavik city and The Ministry of Welfare in Iceland. The purpose was to give unemployed young people at the age of 16-25 years the oppurtunity to get into the labour market or into studies after very intensive and individualised support at the Job Forum. The purpose was also to harmonize the service provided for this group of young people with the focus on those who gets financial assistance from the city of Reykjavik.

The inspiration was brought from the Swedish initiative Jobbtorg Stockholm which has a clear focus on providing oppurtunity for the job seeker to come to a certain place to get individualized support to apply for availible jobs and being able to get part time employment with the support from his/her personal "job coach". This kind of individualized coaching is important for a certain group of young people and will increase their possibilty of being able to support themselves in the nearest future.

\subsubsection{Results}

The project served more than 300 individuals from February 2012 until late summer 2013. Thereof a total of 155 individuals have accepted a job offer having used the support of the Reykjavík job forum. On average some $70 \%$ of the participants who closed their registration at Job Forum got jobs or entered educational programs. The remaining $30 \%$ have been equipped with useful information from their social counsellors and "job-coaches" who continue to assist them in preparing them for the job market. According to the project leaders a majority of the participants were happy with the solutions they got. Those who finished the process have also turned out to be far more active in their search for jobs than the others. 


\subsubsection{Target group}

The project was initially aimed at young people registered as unemployed. The target group is mainly composed of people already receiving municipal financial assistance. Assumingly, the project is best fitted for young people who have not attended secondary schools or dropped out of these. The target group is focused on people who can be said to be relatively far from the open labour market.

\subsubsection{Role of companies, and their benefits}

The project as such encourages companies to get involved and to assume a wider social responsibility, by giving young people with little or none work experience the chance and support to gain such experience. Most participating companies also see this as important, and as good for the company's image. At the same time the companies get the opportunity to get to know the employees under the supervision of a job forum counsellor, which leads to a smooth start-up and helps avoiding conflicts. This is also an inexpensive way to train new employees, as the project gives access to funding during the first months, equal to the unemployment compensation or the municipal financial assistance otherwise paid.

\subsubsection{Collaboration with other actors}

The project was initiated by the Ministry of Welfare, the Directorate of Labour and Reykjavík city. The project also involves trade unions, municipalities, companies and a number of voluntary bodies.

\subsubsection{The funding of the initiative}

This project primarily uses the ordinary sources of funding available to the young unemployed. This means that funding is provided from the Ministry of Welfare, the Directorate of Labour or the local authorities' social security. However, a number of NGOs and the firms invest their time, sometimes without receiving compensation.

\subsubsection{Success criteria}

One of the main conclusions from the project is that personal guidance has the potential to provide the job seeker with increased skills, at the same time as the project opens up a canal of recruitment that was not as easily accessible before. The Job Forum co-operates with Reykjavík city 
and with several private companies, providing a stepping-stone for the participants, who presumably would not have taken the initiative or had the guts to seek this particular job. Personal guidance and tailor made solutions seem to be the most important success criteria, for this project.

Furthermore, an interdisciplinary approach is crucial in this respect. The counsellors and coaches involved have numerous fields of expertise, including social issues, psychology, alcohol and drug counselling, etc. Mandatory attendance on a daily basis (or 2-5 times a week) is also seen as an important success criterion of a major importance, not to mention the essentiality of mutual trust between the job seeker and the counsellor.

The mandatory attendance has been somewhat unpopular among the participants, but has gained acceptance in the long run as people discover how this helps them to get activated. This has also in some cases been the driver needed to get people out to work, since they had to show up somewhere regularly anyhow to keep the social compensation.

\subsubsection{Sharing the experience}

More information is needed before any more precise conclusions can be drawn about the potential of the project to be copied/repeated in other places or abroad.

However, experiences from Iceland may not be easily applicable to other Nordic countries or to the EU, as in Iceland it is quite common for people from 14 years of age to get jobs during the school holiday, e.g. from 10th June to 20th August. Many companies hire young people during the summer as a part of their recruitment policies. As a positive consequence of this young people get to know different work places and different types of job already at young age, which in turn makes them more competitive on the job market later on. At the same time it provides them with useful references from "early employers" for later use. Naturally this widespread practice is not conceived or defined as "a project against youth unemployment", even though it might be quite effective in reducing youth unemployment and preparing youngsters for their future search for job.

The trend described above may reduce the need for formal "projects against youth unemployment" in Iceland, compared to the other Nordic countries and the EU. Young people not attending or dropping out of secondary schools may be the most important target group in this respect, as they may be seen as less competitive when it comes to recruitment for summer jobs. 
Another aspect that might matter when comparing Iceland to other countries is the fact that young people in Iceland attending schools during the winter cannot be registered as unemployed during the summer. This means that they are neither deregistered if and when they get jobs, which in turn may affect the statistical comparison. These people neither get any unemployment compensation benefits.

The observations above may perhaps be said to apply to all the cases below.

\subsubsection{Sources of information}

Tryggvi Haraldsson, Reykjavik Job forum (Atvinnutorg).

Gylfi Arnbjörnsson, president of ASí (Icelandic Confederation of Labour).

\subsection{Opportunity - Young People to Action (Ungt fólk til athafna (Skagastaðir))}

\subsubsection{The initiative in brief}

This project is closely linked to case 7.1, except that this project was local. The project was initiated in 2010 with the purpose to activate young job seekers in Akranes town, especially in their search for a job or suitable educational or training opportunities. All job seekers in the town 18-30 years of age are obliged to spend 8 hours a week in the Skagastaðir centre, where they get training in writing CV's, job seeking, etc. Half of this time is dedicated to group-work, selected by the job seeker, while the remaining 4 hours are free and can be used at the centre at any time of the week for any given purposes. One of the first tasks in all cases is to write a good personal CV with assistance from the project managers. The centre is open daily from 9 a.m. to 3 p.m.

The core idea of Skagastaðir is to be an activation centre for young job seekers, but not a leisure place or a civic centre. All job-seeking youngsters in the region were invited to the centre at the beginning. At a later point the centre was also opened for clients of the municipality's social service.

All registered job seekers are invited to an introductory meeting at The West-Iceland Office of The Directorate of Labour to get them acquainted with their rights and duties as job seekers, followed by another meeting at Skagastaðir to present the service offered there. During the process a project manager has a personal meeting with each of the job seekers twice a 
month, discussing the status in the search for jobs, what has been done, what has been achieved and what should be the next steps.

\subsubsection{Results}

A total of 326 individuals have used the service of Skagastaðir from the beginning of the project in March 2010. According to one survey some 60 out of 90 job seekers who participated in the project were deregistered and had a job within 4 months.

The project managers were employees of The Icelandic Red Cross until the autumn 2012 when the Skagastaðir centre moved to another building owned by Akranes municipality. Since the beginning of 2013 the municipality has been the formal employer of the project managers and the project has been co-financed by the municipality and The Unemployment Benefit Fund. The plan is to keep the project running as long as necessary.

\subsubsection{Target group}

The target group is young job seekers in Akranes town. As noted earlier all job seekers in the town 18-30 years of age are obliged to spend 8 hours a week in the Skagastaðir centre. The project is for people who receive unemployment compensation as well as for people who get financial support from the municipality. Also in this project you may say that this target group includes young people who may be characterised as being relatively far away from the labour market.

\subsubsection{Role of companies and their benefits}

The role of the firms is to offer work places. Most of the companies offer only one work place and smaller business have been more willing to create opportunities for young people than the bigger ones.

\subsubsection{Co-operation of different actors}

The project was initiated by Akranes municipality and carried out in cooperation with The Akranes department of The Icelandic Red Cross as well as The West-Iceland Office of The Directorate of Labour. These actors also secured funding for the basic running of the project to begin with. Apart from that, financing was to a great extent dependent on grants from several different actors. 
As described above, Akranes municipality, The Icelandic Red Cross and The West-Iceland Office of The Directorate of Labour are involved in the project as well as some companies.

\subsubsection{The funding of the initiative}

This project primarily uses the ordinary sources of funding available to the young unemployed, i.e. from the Unemployment Benefit Fund. Salaries are paid partly by the fund and partly by Akranes municipality. However, a number of NGOs and the firms invest their time, sometimes without receiving compensation.

\subsubsection{Success criteria}

According to the managers of the project the obligation to participate is the most important key to success. All participants have to be treated in the same way, at the same time as the service has to be tailor made for each individual in order to activate the best parts of everyone. The mandatory group work is believed to be another major success factor.

In general the project has been successful. It is not a coincidence, according to the responsible actors, that the number of young job seekers is proportionally lower in the region than in other parts of Iceland. This is meant to be a consequence of an excellent co-operation between local and regional institutions and companies, with a high emphasis on personal service and group work to make the clients more active in their search for jobs.

Records of attendance are sent to The Directorate of Labour once a week. If the job seeker is offered a temporary or a part-time job, he or she is exempted from the obligatory attendance, given that Skagastaðir has been informed on forehand. Cases of absence, sick leaves etc., have to be notified and explained in the same way as at a normal work place. Cases of repeated unexplained absence are reported to the payment authority. The job seeker is asked for an explanation and a decision on further payments is made on the basis of this.

Some of the job seekers see the mandatory attendance as a burden or as some kind of punishment, while other perceive it as a good opportunity to get a new job or find suitable education. Most of the participants seem to agree that having a job increases their well-being and makes them feel more as a part of the society. Attending the work at Skagastaðir gives the participants a motivation to carry on and has often led to a decision to apply for some further education. 
Some of the participants were pretty negative towards the initiative at the beginning, found it humiliating and designed for "other kinds of people" who might be difficult or boring to work with. This attitude seems to have changed over time in most cases as the participants started to experience the benefits.

According to the chairman of Akranes Trade Union, the work at Skagastaðir has made quite a difference and yielded some extremely positive results.

\subsubsection{Sharing the experience}

The experience from Skagastaðir could easily be repeatable in other parts of Iceland or abroad.

\subsubsection{Sources of information}

Bryndís Bragadóttir, West-Iceland Office of The Directorate of Labour Drífa Gústafsdóttir, project manager, Skagastaðir.

Guðný Elíasdóttir, project manager, Skagastaðir.

Zanný Lind Hjaltadóttir, job seeker /Skagastaðir.

Unnur Jónsdóttir, job seeker /Skagastaðir.

Vilhjálmur Birgisson, chairman of Akranes Trade Union.

\subsection{Icelandair Technical Services}

\subsubsection{The initiative in brief}

The project was initiated by Atvinnutorg (Job Forum) in Reykjanesbær municipality, and involves collaboration between the Job Forum and Icelandairs subsidiary Icelandair Technical Services (ITS) based at Keflavik International Airport, located in Reykjanesbær municipality. ITS has approximately 300 people employed.

The purpose of the project is to provide young unemployed persons a chance to a temporary appointment within ITS. Initially, the participants receive a two-weeks introduction, followed by a 6 months contract at ITS. One aim is that some of those receiving this contract shall also be hired for longer periods. 


\subsubsection{Results}

All interviewees at ITS report that the initiative so far has been a great success and three participants out of seven were later on permanently employed at ITS.

Although testimonies are somewhat mixed from behalf of the young persons themselves, they also see the experience from the 6 months work as an important experience and a reference making the job market more accessible to them in the future. Even for those not being taken on longer contracts, the project can be seen as having reactivated them and brought them closer to their next job.

\subsubsection{Target group}

The target group for the initiative has been young people registered at the Job forum in Reykjanesbær. At focus have been mainly long-term unemployed people, people who were just about to lose their rights to unemployment compensation due to time limits, or people who had already started receiving social grants from the municipality.

A few other job seekers have contacted the Job forum to get assistance in their search for jobs, even though they were neither registered in advance, nor receiving unemployment compensation.

\subsubsection{The role of companies and their benefits}

ITS did not initiate the project, but demonstrated willingness to take an active part when approached by the Job Forum. The main reason for ITS to be actively involved is that ITS wants to practice social responsibility. Finding employees is not a problem, but ITS is willing to assist in reducing youth unemployment. "We like to see people smile" and get more active, as they claim.

\subsubsection{Co-operation with others}

As described above the project is carried out in close cooperation between ITS and the Job forum. The project has on the other hand not had any direct cooperation with the local or regional trade unions. By establishing this link the Job forum would most likely have had a stronger impact. This could be done by using the experience and knowledge accumulated at the trade unions, such as in the fields of education regarding rights and duties at the job market. 


\subsubsection{Funding the initiative}

The project involves little extra funding, apart from funding for the individuals. The exact fundings available for them will vary from case to case depending on what programme support they are entitled to. However these costs are predominately paid by the Employment directorate, the Municipality or the ITS. Often ITS' share represents parts of the salary.

The project was partly financed by Reykjanesbær municipality, who paid the same amount of money to ITS as would have been the unemployment compensation to the employee. ITS paid the rest.

\subsubsection{Success criteria}

There is no doubt that the project has been successful and in that light it will definitely be continued. However there is no research available concerning the success of the project, the key success criteria or barriers to success. Assumingly however, the positive attitude of ITS towards the project is an important success factor.

According to one of the participants, the project didn't quite meet the expectations. The employees of ITS were very helpful, but more support would have been needed. Training of newcomers could have been better and it was not sufficiently clear from the beginning for how long the project would last, what was expected from the participants, etc. Such things are especially important for people who have been unemployed for a long time, as their confidence may be somewhat low. Going to work right after months or years of inactivity at home may cause a lot of anxiety that needs to be dealt with. ITS did their best, but the Job Forum seems to have been lacking a more proactive approach regarding practical arrangements, including contracting etc.

The experience that the participants got during their work at ITS have in some cases opened up their eyes for educational opportunities, such as within aircraft mechanic. In general the participants seem to be happy with the project, as it has helped them to enter the labour market again.

\subsubsection{Sharing the experience}

It should be possible to copy/repeat the project in other places or abroad. The comments made in section 7.1.8 should however be kept in mind, as well as the above notes on co-operation with the trade unions, training of participants and clarity regarding tasks and timeline. 


\subsubsection{Sources of information}

Guðrún B. Árnadóttir, adviser at Suðurnes Job forum (Atvinnutorg) Steinunn Una Sigurðardóttir, Icelandair Technical Services ITS.

Guðjón Ingi Gunnarsson, job seeker /ITS.

Helga Magnea Eypórsdóttir, job seeker /ITS.

Kristján G. Gunnarsson, chairman of Workers and seamen's Union in Keflavík.

\subsection{Duty Free}

\subsubsection{The initiative in brief}

This project involved collaboration between Reykjanesbaer Atvinnutorg (Job Forum) and the Duty Free store at Keflavik international airport. The project was initiated by Atvinnutorg (Job forum) in Reykjanesbær municipality with the purpose to get young people into the labour market and give them the opportunity to gain some work experience. One important aspect of this is to provide young people who have not had a job for a long time (or ever) with some first-hand experience of the merits and demands of working life. Duty Free employs approximately 140 employees at the airport.

In a way similar to that in case 7.3 The Duty Free store also offered to take on young people from the Job Forum and offer them a 6 month contract with a possible prospect of a longer contract in the end. However the jobs offered at Duty Free were not full-time jobs.

\subsubsection{Results}

The scale of the initiative has until now been quite limited. Only two individuals started on the project to begin with. None of them actually completed the full six-month period.

It can be claimed that Duty Free's long tradition on taking on summer holiday workers in relatively large numbers and then to a high degree retaining them at least throughout the autumn has made it hard for young people coming from the Job Forum to compete over any openings. In addition to that applicants have to have a clean criminal record due to airport security protocols as well as in most cases a driving licence to get to the airport. This somewhat narrows the target group. 


\subsubsection{Target group}

The target group for the initiative has been young people registered at the Job forum in Reykjanesbær. At focus have been mainly long-term unemployed people, people who were just about to lose their rights to unemployment compensation due to time limits, or people who had already started receiving social grants from the municipality.

\subsubsection{The role of the companies and their benefit}

Although Duty Free did not initiate the project the company has remained an important player throughout the project. The main role for the company is to take on young people for short-term contracts.

As in the case for ITS ( 7.3 above) the main reason for Duty Free to engage in this is to be and be seen as an active and socially responsible business.

The company also sees the initiative as an opportunity of lifting some of its already hired works and gives them increased responsibilities by giving them new roles in relation to training the new short time contractors.

However it should be noticed that the small scale of the project so far also limits the merits to companies.

\subsubsection{Collaboration with others and funding of intiative}

The project was run by Job Forum in Reykjanesbaer. Besides the collaboration with Duty Free the project also relied on national and local authorities to provide funding from unemployment benefit programs to those taking part.

\subsubsection{Success criteria}

At the time being, there is only very limited information available on the monitoring of the success of the project, the key success criteria or barriers to success. As stated above none of the participants finished the process, but the numbers in this particular case are too low to allow for any significant conclusions about the success.

\subsubsection{Sharing the experiences}

It should be possible to copy/repeat the project as such in other places or abroad. 


\subsubsection{Sources of information}

Guðrún B. Árnadóttir, adviser at Suðurnes Job forum (Atvinnutorg).

Sóley Ragnarsdóttir, human resource manager, Duty Free Store (Fríhöfnin) - subsidiary of ISAVIA ohf.

Kristján G. Gunnarsson, chairman of Workers and seamen’s Union in Keflavík. 
Nordisk Ministerråd

Ved Stranden 18

DK-1061 København K

www.norden.org

\section{Virksomheders indsats for udsatte unge (Företags insatser för utsatta unga)}

Arbejdsløsheden blandt unge er betydelig større end den generelle arbejdsløshed i de nordiske lande. En voksende gruppe af unge i Norden har risiko for ikke at komme ind på arbejdsmarkedet - ikke blot som ung, men også i deres voksne liv.

Flere og flere virksomheder tager et ansvar i forhold til at hjælpe de unge nærmere en plads på arbejdsmarkedet. Ofte kan virksomheden være vejen til at komme videre i uddannelse eller få læreplads for en ung arbejdsløs. Virksomhederne kan tilbyde de udsatte unge noget andet end $f x$ en sagsbehandler eller et skoleophold kan. De unge får bl.a. mulighed for at prøve sig selv af $\mathrm{i}$ forbindelse med forskellige arbejdsopgaver og brancher, og de lærer noget om ansvar, samarbejde og arbejdsmarkedskultur.

Denne undersøgelse kortlægger eksempler på best practice for virksomheders indsatser for at sikre, at udsatte unge med svag forankring på arbejdsmarkedet kommer i beskæftigelse eller uddannelse. Kortlægningen ser på praksis i de fem nordiske lande: Danmark, Norge, Sverige, Finland og Island. De udvalgte cases har alle til formål at sikre udsatte unges integration på arbejdsmarkedet.

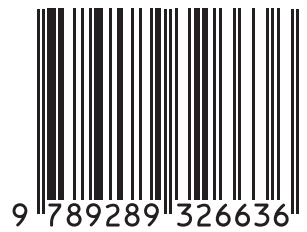

